\title{
Modernising the Constitution: British Territories and Foreign Relations Act: Part 1
}

\author{
Graham McBain ${ }^{1,2}$ \\ ${ }^{1}$ Peterhouse, Cambridge, UK \\ ${ }^{2}$ Harvard Law School, USA \\ Correspondence: Graham McBain, 21 Millmead Terrace, Guildford, Surrey GU2 4AT, UK. E-mail: \\ gsmcbain@aol.com
}

Received: October 5, 2021 Accepted: December 23, 2021 Online Published: December 28, 2021

doi:10.5539/ilr.v11n1p117

URL: https://doi.org/10.5539/ilr.v11n1p117

This article, being Part 1, considers the consolidation of some 150 pieces of constitutional legislation into 1 Act. Part 2 considers the abolition of various Crown prerogatives relating to foreign affairs.

\section{INTRODUCTION}

A previous series of articles has proposed the consolidation of c. 150 pieces of domestic legislation relating to the UK Constitution into 4 pieces of legislation viz. a Crown Act, Parliament Act, Courts Act and a Government Act. ${ }^{1}$ Such, then, can be consolidated into 1 Constitution Act. ${ }^{2}$ Besides this domestic constitutional legislation, there are c. 150 other pieces of legislation which relate to UK territories and to foreign relations. All this material should now be placed in a British Territories and Foreign Relations Act ('BTFRA') in order to excise obsolete provisions and references. Also, to make the same more coherent and accessible. Thus, a BTFRA should contain the following:

- $\quad$ British Territories. This comprises legislation relating to:

- British Overseas Territories ('BOT'); ${ }^{3}$

- British domestic Territories, ${ }^{4}$ viz. the Channel Islands and dependencies, ${ }^{5}$ the Isle of Man and the island of Rockall; 6

- Independence Legislation. This - or, rather, snippets of the same since most sections have been repealed - applies to countries once part of the British Empire (i.e. colonies) ${ }^{7}$ most of which are now part of the Commonwealth; ${ }^{8}$

- $\quad$ Spent Legislation. This comprises legislation relating to foreign compensation, peace treaties etc which is spent and should be repealed in a BTFRA (see 29);

- Other Foreign Affairs Legislation. This relates to things such as the legislation dealing with the Commonwealth, international organisations, the UN and the Antartic. Such should be placed in a BTFRA (see 29).

All the above are discussed in this article, being Part 1. A separate article (Part 2), for ease of convenience, will discuss various Crown prerogatives which govern the relation of the Crown with foreign States and foreign affairs. Such comprise the following:

- Diplomacy. The Crown prerogative to conduct diplomacy;

- $\quad$ Treaties. The Crown prerogative to enter into treaties;

\footnotetext{
${ }^{1}$ GS McBain, Modernising the Constitution - A Crown Act (2021) International Law Research ('ILR'), vol 10, no 1, pp 33-100. Ibid, Modernising the Constitution - A Parliament Act (2021) ILR, vol 10, no 1, pp 101-84. Ibid, Modernising the Constitution - A Courts Act (2021) ILR, vol 10, no 1, pp 195-248. Ibid, Modernising the Constitution - Quangos (2022) ILR, vol 11, no 1, pp 1-61.

${ }^{2}$ That said, it may be better to leave the Courts Act - which is more likely to be amended on a regular basis - distinct.

${ }^{3}$ Presently, there are 14 BOT.

${ }^{4}$ This is not, at present, a definition contained in legislation. However, it is proposed in this article that it should be as a counterpart to a 'overseas' territory. Also, to avoid outdated nomenclature such as 'possession' or 'dependency'.

${ }^{5}$ The Channel islands comprise: Jersey, Guernsey, Alderney, Sark and their smaller islands.

${ }^{6}$ Rockall lies off the coast of Scotland.

${ }^{7}$ The Interpretation Act 1889, s 18(3) defined a colony to mean any part of Her Majesty's ('HM's') dominions exclusive of the British Islands and British India. 'British Islands' meant the UK, the Channel Islands and the Isle of Man.

${ }^{8}$ See Appendix 1, on pp 44-5.
} 
- Ambassadors, Commissioners \& Consular Officials. The Crown prerogative to send (and receive) ambassadors, commissioners, consular and other officials;

- $\quad$ Passports. The Crown prerogative to issue, refuse, impound and revoke passports;

- $\quad$ Territory. The Crown prerogative to acquire foreign territory (including by way of annexation). Also, the Crown prerogative to cede (that is, to give up) territory;

- $\quad$ Foreign States. The Crown prerogative to recognise foreign states.

These Crown prerogatives should also be placed in a BTFRA. Not least, to adapt these prerogatives to present times as well as to clarify their nature and extent. Further - while, in past centuries, foreign diplomacy was conducted by the English sovereign in person - today, the sovereign (Queen Elizabeth II) is a titular (that is, a formal or non-executive) head of State and, instead, government is conducted by ministers and civil servants who are accountable to Parliament. This, despite the legal fiction - which has been long out of date - that they are servants of the Crown. Thus, these Crown prerogatives should now be legislative (where still required) and recognise the formal role of the sovereign. That is, ministers, civil servants etc. should be accountable to Parliament.

In due course the BTFRA should - along with the 4 other Acts mentioned (i.e. the Crown, Parliament, Courts and Government Acts) - be consolidated in a Constitution Act. One benefit of this will be to place British domestic and overseas territories within the context of the UK and its constitution. To date, BOT, the Channel Islands and the Isle of Man have tended to be treated both generally (and in legislation) very much on the sidelines and as rather insignificant. However, such is no longer appropriate.

In conclusion, a BTFRA will consolidate c. 150 (piecemeal) Acts relating to the UK territories and foreign affairs. It will, also, modernise and place into legislation Crown prerogatives relating to such.

\section{LEGAL TEXTS}

There are many legal texts relating to constitutional law. ${ }^{9}$ There are, also, various editions of Halsbury, Laws of England ${ }^{10}$ and Halsbury, Statutes of England. Further, it is useful to refer to the following texts when describing the legal history of the matters discussed in this article in the context of a BTFRA:
- $\quad$ Chitty Jun, A Treatise of the Law of the Prerogatives of the Crown (1820) ('Chitty'), ${ }^{11}$
- Bowyer, Commentaries on Constitutional Law (1846)('Bowyer'); ${ }^{12}$
- Maitland, English Constitutional History (1908) ('Maitland'); ${ }^{13}$
- $\quad$ Feilden, Short Constitutional History of England (1922)('Feilden'); ${ }^{14}$
- Chalmers \& Asquith, Outlines of Constitutional Law (1922) ('Chalmers'), ${ }^{15}$
- $\quad$ Wade \& Phillips, Constitutional Law (1 ${ }^{\text {st }}$ ed, 1931) ('Wade') $;^{16}$
- $\quad$ Ridges, Constitutional Law of England (1934)('Ridges'); ${ }^{17}$
- Anson, The Law and Custom of the Constitution (1935)('Anson'); ${ }^{18}$
- Dicey, Introduction to the Study of the Law of the Constitution (1948 ed) ('Dicey'), ${ }^{19}$
- $\quad$ Plucknett, Taswell-Langmead's Constitutional History (1960)('Plucknett'); ${ }^{20}$
- Jennings, Cabinet Government (1969) ('Jennings'); ${ }^{21}$
- Brazier, Constitutional Practice (1994)('Brazier'); ${ }^{22}$
- $\quad$ De Smith \& Brazier, Constitutional and Administrative Law (1998)('DeSmith');23

\footnotetext{
${ }^{9}$ For an attempt to list the same, see McBain, n 1 (Crown Act), pp 62-8.

${ }^{10}$ Halsbury, Laws of England ( $1^{\text {st }}$ ed, $1907-17$ with supp; $2^{\text {nd }}$ ed, $1931-42$ with supp; $3^{\text {rd }}$ ed, $1953-63$ with supp; $4^{\text {th }}$ ed, 1973 with supp; $5^{\text {th }}$ ed, 2008 with supp). The relevant volumes on constitutional law in the $1^{\text {st }}$ ed were vols $6 \& 7$.

${ }^{11} \mathrm{~J}$ Chitty Jun, A Treatise of the Law of the Prerogatives of the Crown (1820).

${ }^{12} \mathrm{G}$ Bowyer, Commentaries on the Constitutional Law of England (1846).

${ }^{13}$ FW Maitland, English Constitutional History (1 ${ }^{\text {st }}$ ed, 1908) (it contained a course of lectures delivered in 1887-8 at Cambridge university).

${ }^{14}$ HC Feilden, Short Constitutional History of England (1922).

${ }^{15}$ D Chalmers \& C Asquith, Outlines of Constitutional Law (1922).

${ }^{16}$ ECS Wade \& GC Phillips, Constitutional Law (1 ${ }^{\text {st }}$ ed, 1931).

${ }^{17}$ EW Ridges, Constitutional Law of England ( $5^{\text {th }}$ ed, 1934, ed AB Keith).

${ }^{18}$ WR Anson, The Law and Custom of the Constitution (ed AB Keith, $4^{\text {th }}$ ed, 1935).

19 The first edition was in 1885. Reference in this article is to AV Dicey, Introduction to the Study of the Law of the Constitution (1948 ed, edited by ECS Wade).

${ }^{20}$ TFT Plucknett, Taswell-Langmead's English Constitutional History (1960).

${ }^{21}$ I Jennings, Cabinet Government ( $9^{\text {th }}$ ed, 1969, ed ECS Wade).

${ }^{22}$ R Brazier, Constitutional Practice (2 $2^{\text {nd }}$ ed, 1994).

${ }^{23}$ S De Smith \& R Brazier, Constitutional and Administrative Law (1998).
} 
- $\quad$ Munro, Studies in Constitutional Law (1999)('Munro'); ${ }^{24}$

- $\quad$ Leyland, The Constitution of the UK (2012)('Leyland');25

- Bradley et al, Constitutional and Administrative Law (2018)('Bradley'),;

- Barnett, Constitutional and Administrative Law (2020)('Barnett'). ${ }^{27}$

In particular, Chitty is useful to indicate the state of the law in 1820, Wade that in 1931 and Bradley that in 2018. Prior to Chitty (in 1820), there were various texts dealing with the Crown prerogative.

- Staunford, An Exposition of the King's Prerogative (1567-1607) ('Staunford'); ${ }^{28}$

- $\quad$ Coke, Institutes of the Laws of England (1628-41) ('Coke'); ${ }^{29}$

- Hale, Prerogatives of the King (written 1640's) ('Hale');

- Blackstone, Commentaries on the Laws of England (1765-9) ('Blackstone'); 31

- $\quad$ Bacon, A New Abridgment of the Law ( $5^{\text {th }}$ ed, 1795-8) ('Bacon'). ${ }^{32}$

However, all these texts dealt little with constitutional matters concerning foreign relations. Such is unsurprising since up to the time (and including) the reigns of Tudor sovereigns, foreign relations were very much in the hand of the sovereign, rather than Parliament. Especially so in the reigns of Henry VIII (1507-49) and Elizabeth I (15581603). Even after the Glorious Revolution of 1688, William III (1688-1702) involved himself greatly in foreign affairs; perhaps, not unsurprising since he was also Prince of Orange in the Netherlands. However, from the reign of George I (1714-27), ${ }^{33}$ Parliament took over foreign diplomacy to an increasing extent and, by the reign of Queen Victoria (1837-1902), Crown prerogatives relating thereto were, in practice, wholly exercised by ministers and civil servants. ${ }^{34}$ Besides these general legal texts on constitutional law, there are certain specific texts relating to various Crown prerogatives which will be referred to in this article in their context.

\section{CHANNEL ISLANDS}

\section{(a) Introduction}

The Channel islands comprise Guernsey, Jersey, Alderney and Sark. These islands were, formerly, part of the duchy of Normandy. They remained in allegiance to the sovereign of England when Normandy was lost in 1204. Presently, they are called 'Crown Dependencies' 35 or the 'British Islands.' The law of the same is based, in part, on the ancient customs (coutumes) of Normandy. ${ }^{36}$

\section{(b) Evolving Self Goverment}

As with BOT (see 5), the legal situation of the UK with the Channel Islands has been one of evolving selfgovernment. This may be seen from legal texts from Blackstone until modern times. Thus, Blackstone, in the first edition of his Commentaries of the Laws of England in (1765-9), in volume 1 (in 1765) stated:

The islands of Jersey, Guernsey, Sark, Alderney, and their appendages, were parcel of the duchy of Normandy, and were united to the Crown of England by the first princes of the Norman line [a reference to William I (1066-87]. ${ }^{37}$

\footnotetext{
${ }^{24}$ CR Munro, Studies in Constitutional Law (2 ${ }^{\text {nd }}$ ed, 1999).

${ }^{25}$ P Leyland, The Constitution of the United Kingdom (2012).

${ }^{26}$ AW Bradley, KD Ewing \& CJS Knight, Constitutional and Administrative Law (2018). This text is the successor to Wade, see $\mathrm{n} 16$.

${ }^{27} \mathrm{H}$ Barnett, Constitutional and Adminstrative Law (13 ${ }^{\text {th }}$ ed, 2020).

${ }^{28}$ W Staunford, Exposition of the Kinges Prerogative collected out of the great Abridgement of Fitzherbert, and other olde writers of the lawes of England; [with] the process to the same prerogative appertayning.' The first edition was in 1567. Later editions were published in 1567, 1568, 1573, 1577, 1568-77, 1590 and 1607. For texts prior to Staunford dealing with constitutional law see McBain, n 1 (Crown), pp 62-3.

${ }^{29}$ E Coke, Institutes of the Laws of England (W Clarke \& Sons, London, last ed, 1824).

${ }^{30}$ DEC Yale (ed), Sir Matthew Hale's Prerogatives of the King, Selden Society, vol 92 (London, 1976).

${ }^{31}$ W Blackstone, Commentaries on the Laws of England (Oxford, Clarendon Press, 1 st ed, 1765-9, University of Chicago Press rep 1979).

${ }^{32} \mathrm{M}$ Bacon, A New Abridgment of the Law (5th ed, 7 vols, 1798). Volume 5 (prerogative) contains material on the Crown prerogative. The first edition of Bacon was in 1736-66 (5 vols). The last was in 1832 (8 vols). Bacon is useful since it bridged the historical period from Blackstone (1765) to Chitty (1820) and it was detailed. It is clear that Chitty used Bacon when compiling his own text.

${ }^{33}$ George I was not an English speaker and, from 1717, no longer sat in Cabinet, on the basis that his ministers were accountable to Parliament.

${ }^{34}$ Victoria has been (sometimes) much criticised for interfering in government. However, in reality - although she expressed opinions (and had a particular dislike of certain politicians) - she accepted the decline of the sovereign's executive power and rarely sought to exercise any Crown prerogative, as may be seen from AB, The King and the Imperial Crown (1936). See also, for example, the non-exercise of Crown prerogatives in relation to Parliament, McBain, n 1 (Parliament Act), pp 131-2.

${ }^{35}$ Bradley, n 26, p 32 referring to HC 56 (2009-10). A better description would be 'UK Domestic Territories' and, thus, they (and the Isle of Man and Rockall) would be the domestic counterpart to BOT.

${ }^{36}$ For early legal texts dealing with the Channel Islands in general see Sweet \& Maxwell, A Legal Bibliography of the British Commonwealth of Nations (1955) ('Sweet'), vol 1, pp 583-7. Also, vol 2, pp 397-401. Together, they list legal texts up to 1957.

${ }^{37}$ Cf. De Smith, n 23, p 59 'When the Duke of Normandy became king of England in 1066 [i.e. William I (1066-87], the Channel Islands were already part of the dukedom; and when king John [1199-1217] lost the mainland of Normandy [in 1204], they remained as possessions of the Crown.
} 
They are governed by their own laws, which are for the most part the ducal customs of Normandy...[These islands] are not bound by common acts of our parliaments, unless particularly named. All causes are originally determined by their own officers, the bailiffs and jurats of the islands; but an appeal lies from them to the king in council [i.e. now to the Judicial Committee of the Privy Council, the JCPC], in the last resort. ${ }^{38}$

Chitty, writing in 1820, stated:

The islands of Jersey, Guernsey, Sark, Aldernay and their appendages, were formerly parcel of the duchy of Normandy, and were united to the Crown of England by the first prince of Norman time [i.e. William I, 1066-87]. They are governed by their own separate laws, and are not bound by our statutes, unless particularly named; though an appeal lies from the judicial decision in the island to the king in council [i.e. now, the JCPC], as it does in general from all territories, as the colonies etc subject in this manner to the Crown, though they cannot regularly transmit a cause to the king without first giving some judgment in it. ${ }^{39}$

Maitland (writing in 1887-8) stated:

The Isle of Man and the Channel Islands are not parts of the [UK], though king and parliament can make laws for them. The statutes [Acts] made by Parliament do not affect them unless they are specially mentioned, or it is evident from the context that they were within the purview of the legislature. ${ }^{40}$ The appeal from their courts is not to the House of Lords, but to the king in council [i.e. the JCPC]. The interest of these small dependencies lies in this, that the relation between them and England formed a precedent for the treatment of the vaster dependencies which have gradually collected around the [UK]. ${ }^{41}$

More recently, De Smith (in 1998) stated:

The Channel Islands and the Isle of Man are not parts of the [UK], though in some legal contexts the term '[UK]' is deemed to include them. Within the [UK] they constitute the British Islands. They are dependencies of the Crown, and belong to [HM's] dominions. Although they fall within the definition of a 'British possession', they are not colonies. Their status is unique. The islands have other points of similarity. They have ancient institutions. Their affairs are subject to a degree of superintendence by the Home Office ['HO'], acting on the recommendation of the Committees of the Privy Council for the affairs of Jersey and Guernsey and for the Isle of Man, and petitions relating to matters arising in the islands may be directed to the Privy Council.

The principal channel of communication between the islands and the [UK] government is the [HO], and the Home Secretary is the dominant figure in the Privy Council committees, which today never meet as deliberative bodies. Assent to local legislation is given by order in council and is not a mere formality. Modifications to measures passed by the States of Jersey and Guernsey are still sometimes made after representations by or through the [HO]...Public administration ins each of the principal islands is conducted mainly through committees or boards of the legislatures; in this respect the pattern resembles that of a British local authority, and particularly in the Channel Islands there is no clear-cut separation of powers between the executive and legislature. The customary law, on which the local law was once based, is being replaced by more modern legislation... The [UK] government is responsible for the defence and international relations of all the islands.

Finally, Barnett (2020) states:

The [Channel] islands are organised under two separate bailiwicks: the bailiwick of Jersey and the bailiwick of Guernsey, which includes Alderney and Sark. Each bailiwick enjoys its own legislature, court structure and system of law. Alderney and Sark, whilst part of the Guernsey bailiwick, enjoy a large measure of independence, having their own legislative assemblies. The States of Jersey comprises 52 elected members and five non-elected members. The States of Guernsey comprises 61 members. Official links between the Crown and the [UK] government are through the lieutenant governor of the bailiwicks. The legislature - the States - is headed by the bailiff and the deputy bailiff. ${ }^{42}$

In conclusion, the Channel Islands have their own legislatures (legislatives assemblies) and, thus, have acquired an increased measure of self-government.

\footnotetext{
${ }^{38}$ Blackstone, n 31, vol 1, p 104.

${ }^{39}$ Chitty, n 11, p p 28-9. See also Bowyer (in 1846), n 12, p 36.

${ }^{40}$ This statement contradicts Blackstone and Chitty and Maitland provided no authority for it (cf. $\mathrm{n}$ 54). Today, in any case, it would seem important that they are bound only by express mention since Guernsey etc have their own legislatures.

${ }^{41}$ Maitland, n 13, p 337.

${ }^{42}$ Barnett, n 27, p 25. She continued 'The European Convention of Human Rights applies to the Channel Islands. Because the Channel Islands are not part of the [UK] but are Crown dependencies, the Convention takes effect not under the Human Rights Act 1998 but separate distinctive legislation. That legislation was passed by the legislatures of Jersey, Guernsey, Alderney and Sark but did not become law until given the royal assent. Once in force, the English courts had no jurisdiction to rule on challenges in relation to the Convention. The Supreme Court so ruled in $R$ (Barclay) v Lord Chancellor and Secretary of State for Jersey (no 2)(2014).' [2009] UKSC 9.
} 


\section{(c) The Islands}

The Channel Islands lie off the coast of France and comprise the bailiwicks of Guernsey and Jersey. ${ }^{43}$

- Guernsey is the largest of the Channel Islands; then ${ }^{44}$

- Jersey, then, ${ }^{45}$

- Alderney, then

- Sark. $^{46}$

The status of Guernsey and Jersey in relation to the UK is now similar. ${ }^{47}$ Guernsey legislates for the adjoining islands of Herm and Jethou, which may be treated as its dependencies.

\section{(d) UK Legislation relating to the Channel Islands}

Present UK legislation extant comprises (it seems) the Jersey and Guernsey (Financial Provisions) Act 1947, s 1 (Payments out of Consolidated Fund to Jersey and Guernsey) which states:

There shall be issued out of the Consolidated Fund ....at such times as the Treasury may direct and shall be paid to the States of Jersey or the States of Guernsey sums equal to any sums paid into the Exchequer on or after [1 April 1947], on account of hereditary revenues of the Crown which have accrued in the island of Jersey or the island of Guernsey, as the case may be. The reference in this section to the island of Guernsey includes a reference to the island of Jethou. ${ }^{48}$

There is also the Alderney (Transfer of Property) Act 1923 (Transfer of Property, \&c), s 1 states:

(1) It shall be lawful for [HM] from time to time by Order in Council [OIC] provide for the transfer and vesting of any property, rights, duties and liabilities of $[\mathrm{HM}]$ or of any Government department in or in connection with the Island of Alderney to or in any Government department, or the States of Alderney or any person or persons appointed by the States of Alderney in that behalf.

(2) Any transfer effected by [OIC] under this Act shall be deemed to have taken effect as from such date or dates as may be specified in the Order, and the Order may provide that the transfer shall be subject to such terms and conditions as may be specified in the Order, and may contain such consequential and supplemental provisions as appear to [HM] to be necessary or expedient for the purpose of giving full effect to the Order, and may be revoked or varied by a subsequent Order.

\section{This legislation should be inserted in a BTFRA if not repealed.}

\section{(e) Lieutenant Governor}

These are appointed by the sovereign. However, since all of Guernsey, Jersey, Alderney and Sark now have their own legislatures, consideration might be given whether they - and their powers under the Crown prerogative which are considerable - are still appropriate. To avoid the sovereign (who only has a formal role now) being involved in politics, it may be preferable for these governors (if retained) to be appointed by the Channel Islands

\footnotetext{
${ }^{43}$ Cf. De Smith (in 1998), n 23, p 59 'Within the bailiwick of Guernsey lie the only two other Channel Islands having a sizable population, Aldermey and Sark. Aldernay has its own representative legislature, the States, and provides certain local services, but in 1948 responsibility for all the main services was vested in Guernsey. Sark, though nominally a dependency of Guernsey, is substantially autonomous. Owned by a feudal lord with anachronistic institutions, Sark... is a survival of an age long past.'

${ }^{44}$ For old legal texts, see, in particular: (a) W Berry, History of the Island from the Remotest Period, including its government, privileges, customs etc (1815); (b) T Dicey, Historical Account of Guernsey, giving a particular description of the Laws, Privileges etc; with remarks on Jersey and other islands belonging to Great Britain on the French Coast (1751); (c) J Warburton, Treatise on the History, Laws and Customs of Island of Guernsey (1822). See generally, Sweet, n 36, vol 1, pp 584-5.

${ }^{45}$ Ibid: (a) AE Dryden, Constitution of Jersey. A concise view of the Legislative Powers of the Crown over the Island of Jersey from the tenth century to the present time (1854); (b) C Le Quesne, Constitutional History of Jersey (1856); (c) W Plees, Account of the Island of Jersey...including a statement of its polity, laws, privileges etc (1817). See generally, Sweet, $\mathrm{n} 36$, vol 1, pp 584-5.

${ }^{46}$ Ibid, p 587. See L Selosse, L'Ille de Sark: Etat feudal au XXe siècle (2 ${ }^{\text {nd }}$ ed 1929).

${ }^{47}$ De Smith (in 1998) noted, n 23, p 60 'The Crown used to legislate for Jersey by prerogative order in council, but as the island has acquired a legislature with an elected majority an attempt to do so today would probably be improper. Parliament retains, in strict law, plenary legislative authority for all those parts of [HM's] dominions which have not attained independence or over which Parliament has not renounced its sovereignty. Acts of Parliament extend to Jersey only by express words or necessary implication. The Act is accompanied by an order in council directing that it be registered in the Royal Court. The insular authorities may suspend but not refuse registration; in any event, it would appear that such an Act is operative in the island of its own force. In practice, Parliament hardly ever legislates directly for an island; and an Act intended to alter the law of the island will provide for its extension to the island by order in council made under the Act with such modification of the Act as may be specified in the order. Consultation with the insular authorities will then take place and an accommodation will be reached. It would be contrary to constitutional practice for Parliament so to legislate for the island as to impose taxation or to regulate matters of purely domestic concern or derogate from the island's constitutional autonomy without the consent of the States. Under ancient royal grants, the island has been given immunity from [UK] taxation - it has its own fiscal laws - and the right to duty-free entry of its produce into the [UK]. Guernsey and Jersey made voluntary contributions towards [UK] defence.'

${ }^{48}$ Jethou is a privately leased island of c. 44 acres part of the bailiwick of Guernsey.
} 
${ }^{49}$ and to have only a formal role. Or, to be abolished. ${ }^{50}$ In conclusion, the Crown need not (should not) be involved in the appointment, or dismissal, of the same. ${ }^{51}$

\section{(f) $\underline{\text { Reform }}$}

As noted in prior articles, ${ }^{52}$ today, the sovereign (in person) only exercises a formal role, as opposed to an executive one. Further, as for the Crown in the body politic, the privy council - as previously noted ${ }^{53}$ - also, has long exercised only a formal role and it has (long) been superceded by the Cabinet and ministries (including their civil servants whose salaries are paid for by taxation). Thus, in order to ensure greater accountability and transparency in the relations between the UK and the Channel Islands, it is suggested that a BTFRA should provide that:

- $\quad$ the HO is the relevant ministry dealing with the Channel Islands;

- all legislation relating to the Channel Islands should be by means of general legislation or a SI. This will (and should) exclude the Crown acting by way of charter (including letters patent);

- UK legislation should apply to the Channel Islands only when express - and not when implied; ${ }^{54}$

- the privy council should no longer be involved with the Channel Islands (assuming it is not otherwise abolished). Instead, the HO should handle all matters;

- $\quad$ any older UK legislation relating to the Channel Islands should be placed in a BTFRA. Also, all SI consolidated. The general legislation referred to in (d) may no longer be needed;

- $\quad$ express provision should be made in a BTFRA that the UK is responsible for the foreign relations of the islands and for their defence;

- the term 'Crown dependency' should be supplanted by that of 'British Domestic Territory' - to reflect the fact that BOT comprise British Overseas Territories;

- $\quad$ an appeal from a Channel Islands court should no longer be to the Judicial Committee of the Privy Council (which should be abolished or merged with the UK Supreme Court) but to the Supreme Court. ${ }^{55}$ This should not be a problem since the judges sitting are the same and the JCPC only acquired its jurisdiction by way of an anomaly (there being no Supreme Court in the past). Presently, there is difficulty where the JCPC and the Supreme Court reach different conclusions, ${ }^{56}$

- the role of the lieutenant governors should be reviewed. Since the Channel Islands have their own legislatures, it may appropriate for the same to be a professional appointment to avoid politics and to ensure impartiality.

Above all, provision for BOT (see later, 5) and the Channel Islands as territories should (generally) be similar. And, there is no good reason why it should be otherwise. ${ }^{57}$ Further - given that Guernsey, Jersey, Alderney and Sark now have their own legislatures - the need for UK legislation (whether general or by way of SI) may be expected to be (very) much less than hitherto.

\section{In conclusion, a BTFRA should deal with the Channel Islands. \\ 4. ISLE OF MAN}

The Isle of Man (Mona), situated in the Irish sea, had its own kings (the Stanleys) in the past. ${ }^{58}$ An important report was issued with respect to its government in $1792 .{ }^{59}$ The island was purchased by the Crown in 1765 . It

\footnotetext{
${ }^{49}$ As with BOT governors, lieutenant governors are appointed by the sovereign on the advice of ministers.

${ }^{50}$ It may be noted that the power and duties of the lieutenant governor were never so extensive as those in the case of the Isle of Man, as Anson (in 1935) noted, n 18, vol 2, Pt 2, p 54.

${ }^{51}$ In the case of BOT, it is suggested that governors be civil servants of the FCDO and MOD. Thus, they should be wholly professional appointments where the individual is not involved in politics. Further, it shields the Crown (and Parliament and politicians) from any allegations of partiality or cronyism.

${ }^{52}$ See $n 1$.

${ }^{53}$ See McBain, $n 1$ (Government Act), pp 82-4.

${ }^{54} \mathrm{Cf}$. Barnett, n 27, p 25 'Acts of Parliament extend to the islands only if the statute expressly so provides, or where the Act applies to all [HM's] dominions 'by necessary implication' citing Sodar and Man (Bishop) v Derby (Earl) (1751). [2Ves Sen 337].

${ }^{55}$ See McBain, n 1 (Courts Act), p 201.

${ }^{56}$ I Hendry \& S Dickson, British Overseas Territories Law ( $2^{\text {nd }}$ ed, 2018), n 65, p 29 'Difficulty and confusion are likely to arise where the [JCPC] and UK courts reach different conclusions on the same point of principle, as has sometimes happened.'

${ }^{57}$ As Maitland (see n 13) correctly noted, colonial legislation was based on that for the Channel Islands. However, with BOT, this has come adrift rather. There should be modern legislation today which is similar, reflecting the role that both are UK territories.

${ }^{58}$ For early legal texts dealing with the Isle of Man, see Sweet, n 36, vol 1, pp 588-90. See, in particular: (a) J Johnson, View of the Jurisprudence of the Isle of Man (1811); (b) A Ross, Mona, or the History, Laws and Constitutions of the Isle of Man (1744); (c) R Sherwood, Constitution of the Isle of Man (1882); (c) J Train, Historical and Statistical Account of the Isle of Man (1845); (d) G Waldron, Description of the Island of Man (1731), (e) WP Ward, Isle of Man and Diocese of Sodor and Mann (1837). See also vol 2, pp 403-4.

${ }^{59}$ Report of the Commission of Inquiry respecting the Government and State of the Isle of Man (1792), See also Sherwood, $\mathrm{n} 58$.
} 
has its own Parliament - the Tynwald Court (also, called the High Court of Tynwald) established more than 1000 years ago.

(a) $\underline{\text { History }}$

Blackstone, in the first edition of his Commentaries of the Laws of England in (1765-9), in volume 1 (in 1765) summed up the history of this island:

the Isle of Man is a distinct territory from England and is not governed by our laws; neither doth any act of Parliament extend to it, unless it be particularly named therein; and then an act of Parliament is binding there. It was formerly a subordinate feudatory kingdom, subject to the kings of Norway; and then John [1199-1215] and Henry III [1215-72] of England; afterwards to the kings of Scotland; and then again to the Crown of England: and at length we find king Henry IV claiming the island by right of conquest; and disposing of it to the earl of Northumberland; upon whose attainder it was granted (by the name of the lordship of man) to Sir John Stanley by letters patent 7 Hen IV [1405].

In his lineal descendents it continued for eight generations, till the death of Fernando earl of Derby, AD 1594; when a controversy arose concerning the inheritance thereof, between his daughters and William his surviving brother: upon which a doubt was started concerning the validity of the original patent, the island was seized into the Queen's hands [i.e. Elizabeth I, 1558-1603], and after various grants were made of it by king James the first [1603-25]; all which being expired or surrendered, it was granted afresh in 7 Jac I [1609] to William, Earl of Derby, and the heirs male of his body, with remainder to his heirs general; which grant was the next year confirmed by Act of Parliament, with a restraint on the power of alienation by the said earl and his issue male. On the death of James, earl of Derby, AD 1735, the male line of earl William failing, the Duke of Atholl succeeded to the island as heir general by a female branch. In the mean time, though the title of king had long been disused, the earls of Derby, as lords of Man, had maintained a sort of royal authority therein; by action.

Yet, though no English writ, or process from the courts of Westminster, was of any authority in Man, an appeal lay from a decree of the lord of the island to the king of Great Britain in council. But, the distinct jurisdiction of this little subordinate royalty being found inconvenient for the purposes of public justice, and for the revenue, (it affording a convenient asylum for debtors, outlaws, and smugglers), authority was given to the treasury by statute 12 Geo $1 \mathrm{c} 28$ [1725] to purchase the interest of the then proprietors for the use of the Crown: which purchase hath at length been completed in this present year 1765, and confirmed by statutes 5 Geo III c 26 and 39 [1765] whereby the whole island and all its dependencies, so granted as aforesaid, (except the property of the Atholl family, their manerial [sic] rights and emoluments, and the patronage of the bishoprick and other ecclesiastical benefices) ${ }^{60}$ are unalienably [i.e, inalienably] vested in the Crown, and subjected to the regulation of the British excise and customs. ${ }^{61}$

Chitty (writing in 1820) noted:

The Isle of Man is a distinct territory from England, and is not governed by our laws; nor does an Act of Parliament extend to it, unless it be particularly named therein, and then an Act of Parliament is binding there. The isle had generally been vested by royal grant in the hands of English subjects, who exercised a species of royal authority therein, by assenting or dissenting to laws, and exercising an appellate jurisdiction, though an appeal lay from a decree of the lord of the island to the king of Great Britain in council. This island is now vested unalienably in the Crown, by purchase, and subjected to the regulations of the British excise and customs. ${ }^{62}$

More recently, Barnett (2020) summarises the position:

The Isle of Man became formally linked with England in 1405. From that time until 1765, it was ruled by 'kings' or 'lords' of Man. Under Acts of Parliament of 1765 and 1825, the Westminster Parliament assumed, in the name of the Crown, the rights of the lords. In 1958, under the Isle of Man Act of that year, much control over the island was relinquished by Westminster. The isle enjoys full powers of self-government and has its own system of courts and law. The head of the executive, the lieutenant governor of the Isle of Man, is the formal link between the local administration and the Crown and [the UK] government. The Parliament (the Court of Tynwald) has executive and legislative functions. It comprises the lieutenant governor, the legislative council and the House of Keys. The lower house - the House of Keys - has 24 members elected on a constituency basis for a five-year term of office. The Legislative Council comprises the senior bishop, the attorney general, a judge and seven members elected by the House of Keys. ${ }^{63}$

\footnotetext{
${ }^{60}$ It may be noted that while the feudal rights were sold to the Crown in 1765, the manorial rights and patronage were acquired in 1929, see Anson (in 1935), n 18, vol 2, pt 2, p 53. Thus, the position is different with respect to the Channel Islands where there are still some feudal rights.

${ }^{61}$ Blackstone, n 31, vol 1, pp 103-4.

${ }^{62}$ Chitty, n 11, p 28. De Smith (in 1998), n 23, p 62 put the matter more succinctly 'The constitutional history of the island is convoluted. Till 1266 it was under Norse rule; then it was ceded to the king of Scotland; early in the fourteenth century it passed, somewhat obscurely, to the king of England, who grants it to subjects, styled Lords of Man. In 1765 it was revested in the Crown by Act of Parliament' [i.e. the Isle of Man Purchase Act 1765]. A fn notes 'There is no corresponding or analogous legislation for the Channel Islands.' See also Bowyer (in 1846), n 12, p 36.

${ }^{63}$ Barnett, n 27, pp 24-5.
} 


\section{In conclusion, the Isle of Man (like the Channel Islands) has its own legislature (legislative assembly) and an} increased measure of self-government.

\section{(b) UK Legislation applying to Isle of Man}

As to UK general legislation which applies to this island, the Isle of Man Act 1979, ss 1-14 (still extant) makes provision on customs duties (tariffs). For example, s 1 states:

S 1, (Common duties). (1) Subject to [ss (2) below], in this Act "common duties" means -

(a) customs duties chargeable on goods imported into the [UK] or the Isle of Man;

(b) excise duties chargeable on goods ...imported into or produced in the [UK] or the Isle of Man;

(c) pool betting duty chargeable under the law of the [UK] or the Isle of Man;

(ca) lottery duty chargeable under the law of the [UK] or the Isle of Man;

(d) value added tax chargeable under the law of the [UK] or the Isle of Man except tax chargeable in accordance

with s 23 of the Value Added Tax Act 1994 (gaming machines);

(e)...

(f) soft drinks industry levy chargeable under the law of the [UK] or the Isle of Man.

(2) The Treasury may by order amend [ss] (1) above by adding or deleting any duty or tax which is under the care and Management of the Commissioners of Customs and Excise (in this Act referred to as "the Commissioners") or any corresponding duty or tax chargeable under the law of the Isle of Man; and any such order may apply to a duty or tax generally or in such cases or subject to such restrictions as may be specified in the Order

(3) The power to make orders under [ss (2)(2) above shall be exercisable by [SI] subject to annulment in pursuance of a resolution of the House of Commons. ${ }^{64}$

Other sections deal with: s 2 (Isle of Man share of common duties); 3 (recovery of common duties chargeable in Isle of Man), 4 (enforcement of Isle of Man judgments for common duties), 5 (offences relating to common duties etc), 6 (VAT), 7 (car tax), 8 (removal of funds from the Isle of Man to the UK), 9 (removal of funds from the UK to the Isle of Man), 10 (exchange of information), 11 (transfer of functions to Isle of Man authorities), 12 (proof of Acts of Tynwald etc), 14 (short title). ${ }^{65}$

There may also be other legislation. ${ }^{66}$

\section{(c) $\underline{\text { Reform }}$}

The Isle of Man should be the same as the Channel Islands. Thus, in order to ensure greater accountability, a BTFRA should:

- indicate that the $\mathrm{HO}$ is the relevant ministry dealing with the island;

- all legislation relating to the island should be by means of general legislation or a SI;

- UK legislation should apply to the island only when express and not when implied;

- $\quad$ the privy council should no longer be involved with the island (assuming it is not otherwise abolished);

- $\quad$ any older UK legislation relating to the island should be placed in a BTFRA and any SI consolidated;

- $\quad$ express provision should be made that the UK is responsible for the foreign relations of the island and for its defence;

\footnotetext{
${ }^{64}$ See also S 2. (Isle of Man share of common duties). (1) Of the moneys standing to the credit of the General Account of the Commissioners an amount ascertained for each financial year in accordance with [ss] 2) below shall be paid by the Commissioners, at such times and in such manner as they may determine, to the Treasurer of the Isle of Man. (2) There shall be calculated in such manner as the Treasury may direct (a) the amount of common duties, whether collected in the [UK] or the Isle of Man, which is attributable to goods consumed or used in the Island, to services supplied in the Island or (as respects pool betting duty) to bets placed by persons in the Island; (b) the cost incurred by the Commissioners in collecting the amount so attributable together with the amount of any drawback or repayment referable to that amount; and the amount arrived at by deducting from the amount calculated under paragraph (a) above the amount calculated under paragraph (b) above shall be known as the net Isle of Man share of common duties; and the amount mentioned in [ss] (1) above shall be the excess of the net Isle of Man share of common duties over the common duties collected in the Island. (3) For the purposes of this [s] the amount of common duties collected in the Isle of Man and the [UK], or in the Isle of Man, shall be calculated by reference to the amount so collected in respect of such duties after giving effect to any addition or deduction provided for under [s] 1 of the Excise Duties (Surcharges or Rebates) Act 1979 or any Isle of Man equivalent. (4) The Commissioners shall for each financial year prepare, in such form and manner as the Treasury may direct, an account showing the payments made by them under this section and shall send it, not later than the end of November in the following financial year, to the Comptroller and Auditor General, who shall examine and certify the account. (5) The Comptroller and Auditor General shall send every account examined and certified by him under this $[\mathrm{s}]$ and his report thereon to the Treasury and a copy of every such account and report to the Treasurer of the Isle of Man; and the Treasury shall lay copies of the account and report before Parliament.

${ }^{65}$ Cf. Anson (in 1935), n 18, vol 2, Pt 2, p 53 'The Imperial [i.e. UK] Parliament determines the amount of the customs duties.'

${ }^{66}$ For example, are the Isle of Man (Customs) Acts 1902 and 1952 and the Isle of Man (Church Building and New Premises) Act 1897 still of worth, if not repealed?
} 
- the term 'Crown dependency' should be supplanted with that of British Domestic Territory (to reflect the fact that BOT comprise British Overseas Territories);

- an appeal from a Channel Islands court should no longer be to the Judicial Committee of the Privy Council (which should be abolished or merged with the UK Supreme Court) but to the Supreme Court, ${ }^{67}$

- $\quad$ the position of lieutenant governor should be reviewed, as with the Channel Islands.

\section{BRITISH OVERSEAS TERRITORIES ('BOT') - BACKGROUND}

Useful general texts on BOT are Roberts-Wray, Commonwealth and Colonial Law (1966) ${ }^{68}$ (now dated) and the more recent Hendry \& Dickson, British Overseas Territories Law ( $2^{\text {nd }}$ ed, 2018). ${ }^{69}$ There is, also, Halsbury, Laws of England.

\section{(a) History to WW 2 (1939-45)}

From Elizabethan times, the UK developed an empire which - at its height in Victorian times - covered a quarter of the globe. It did this through the creation of colonies $^{70}$ or plantations - the latter word tending to refer to colonies that were voluntarily settled and established by way of charter as opposed to those taken by way of conquest or treaty. Chitty (writing in 1820) stated:

Our plantations or colonies in America, and in other parts of the globe, were of course obtained either by conquest or treaty, or by our taking possession of, and peopling them, when we found them uninhabited. When a country is obtained by conquest or treaty, the king possesses an exclusive prerogative power over it, and may entirely change or new-model the whole, or part of its laws, and political form of government, and may govern it by regulations framed by himself... ${ }^{71}$

Colonies were categorised by Chitty (writing in 1820) as:

- $\quad$ Provincial Establishments. Their constitutions depended on the commissions issued by the Crown to the governors and the instructions which (usually) accompanied them;

- $\quad$ Proprietary Governments granted by the Crown to individuals;

- $\quad$ Charter Governments in the nature of civil corporations. The charter provided for a power to make byelaws for their internal regulation, not contrary to the laws of England and with rights and authorities given them in the charters. ${ }^{72}$

However, from Victorian times, there was an involvement of Parliament in the governing of colonies, such that their operation by virtue of exercising the Crown prerogative alone was progressively reduced. ${ }^{73}$ Later, as well as colonies and plantations, there were:

- $\quad$ protectorates $;^{74}$

- $\quad$ associated states ${ }^{75}$ and, after WWI (1914-8),

- mandated territories. $^{76}$

\footnotetext{
${ }^{67}$ See McBain, n 1 (Courts Act), p 201.

${ }^{68} \mathrm{~K}$ Roberts-Wray, Commonwealth and Colonial Law (1966).

${ }^{69}$ Hendry, n 56.

${ }^{70}$ For pre-1800 material on colonies, see Sweet, n 36, vol 1, pp 507, 518 and 520 including: (a) W Earnshaw, Digest of the Laws from 12 Car 11 to 58 Geo III, relating to shipping, navigation, commerce and revenue, in the British colonies, in America, and the West Indies, including the laws abolishing the Slave Trade (1st ed 1818, $3^{\text {rd }}$ ed, 1820); (b) W Beawes, Lex Mercatoria Rediviva; or, Merchant's Directory, containing an account of our trading companies and colonies, duty of consuls, laws relating to aliens, naturalization etc $\left(1^{\text {st }}\right.$ ed 1752 , last ed $\left(6^{\text {th }}\right.$ ed, 1813) and (c) G Chalmers, Opinions of Eminent Lawyers [1669-1809] on various points of English jurisprudence, chiefly concerning the colonies, fisheries and commerce of Great Britain (1814, rep in 1 volume, 1858). For a useful description of how the colonies developed, see DL Keir, The Constitutional History of Modern Britain since $1945\left(9^{\text {th }}\right.$ ed, 1969).

${ }^{71}$ Chitty, n 11, p 29. He continued 'For instance, ever since the conquest of Gibraltar [in 1704], in which, besides the garrison, there are inhabitants, property, and trade, the king has made orders and regulations suitable to those who live etc or enjoy property that place.' See also Bowyer (in 1846), n 12, ch 4, Maitland (in 1887-8), n 13, pp 337-8 (colonies) and Halsbury, Laws (1909), vol 6, pp 421-7.

${ }^{72}$ Chitty quoted Blackstone, see n 31, vol 1, pp 104-6.

${ }^{73}$ For useful material, see S Amos, Fifty Years of the English Constitution 1830-1880 (1880), pp 150-77 'The constitutional history of British dependencies may be compendiously described as that of a gradual transfer of the functions of government from the Crown, in the exercise of a well-recognised prerogative, to Parliament...'. See also Campbell v Hall (1774) 20 ST 323 in which Mansfield CJ held that the power of the Crown to give a constitution to a conquered country was not exclusive of Parliament and such country was necessarily subject to the legislative power of Parliament. Ibid, p 157.

${ }^{74}$ For protectorates see Chalmers, n 15, pp 168-9. See also WE Hall, A Treatise on the Foreign Powers and Jurisdiction of the British Crown (1894). Also, Ridges (in 1934), n 17, ch 4.

${ }^{75}$ The comprised 6 Caribbean territories in a special status of association with the UK under the West Indies Act 1967. The last to achieved independence was St Christopher and Nevis in 1983. Thus, there are now none. See Hendry, n 56, p 6.

${ }^{76}$ See also Chalmers, n 15, p 170 and Wade (in 1931), n 16, pp 371-2. Also, Ridges (in 1934), n 17, ch 5.
} 


\section{(b) Post WW2 - Move to Self Government}

After World War II (1939-45), there was a process by which colonies became independent countries, ${ }^{77}$ although many continued their association with the UK by becoming members of the British Commonwealth (now called the 'Commonwealth'). In the case of British protectorates, ${ }^{78}$ mandated territories ${ }^{79}$ and associated states. these ended.

\section{(c) Present BOT}

Today, 14 former colonies exist as BOT viz.

\begin{tabular}{|c|c|c|}
\hline$\underline{\text { BOT }}$ & Pop. & $\underline{\text { Has Legislature }(\mathrm{L})^{80}}$ \\
\hline Anguilla $^{81}$ & $15 \mathrm{k}$ & $\mathrm{L}$ and Governor \\
\hline Bermuda 82 & $71 \mathrm{k}$ & $\mathrm{L}$ and Governor \\
\hline British Antartic Territory (BAT) & No permanent & Commissioner \\
\hline British Indian Ocean Territory (BIOT) & No permanent & Commissioner \\
\hline British Virgin Islands $(B V I)^{83}$ & $35 \mathrm{k}$ & $\mathrm{L}$ and Governor \\
\hline Cayman Islands ${ }^{84}$ & $66 \mathrm{k}$ & $\mathrm{L}$ and Governor \\
\hline Falkland Islands ${ }^{85}$ & $3.3 \mathrm{k}$ & $\mathrm{L}$ and Governor \\
\hline Gibraltar $^{86}$ & $32 \mathrm{k}$ & $\mathrm{L}$ and Governor \\
\hline Monserrat ${ }^{87}$ & $5 \mathrm{k}$ & $\mathrm{L}$ and Governor \\
\hline Pitcairn Islands ${ }^{88}$ & c. 45 & Governor $^{89}$ \\
\hline St Helena, Ascension \& Tristan da Cunha ${ }^{90}$ & $4.4 \mathrm{k}$ & L and Governor (or Governor) ${ }^{91}$ \\
\hline South Georgia \& South Sandwich Islands & No permanent & Commissioner \\
\hline SBA of Akrotiri \& Dhekelia ${ }^{92}$ & c. $18 \mathrm{k}$ & Administrator \\
\hline
\end{tabular}

\footnotetext{
${ }^{77}$ India and Ceylon (Sri Lanka) became some of the first, see the Indian Independence Act 1947 and the Ceylon Independence Act 1947. See also Appendix 1.

${ }^{78}$ DM Walker, The Oxford Companion to Law (1980) (protecrorate) 'In the history of the British Empire and Commonwealth a protectorate or protected state frequently existed by treaty with a native ruler or chief under which the territory was administered in a way generally similar to that in Crown colonies.'

${ }^{79} \mathrm{Ibid}$, (mandate). After World War I [1914-18] certain territories and colonies of Germany and Turkey were detached from them and entrusted by the League of Nations to 'mandatory states' to administer on behalf of the League on conditions laid down in mandates between the League and each mandatory...After World War II [1939-45], the system was replaced under the United Nations by the trusteeship system.'

${ }^{80}$ See, generally, on this Hendry, n 56, p 10.

${ }^{81}$ Anguilla (a former British Crown colony) is a self governing BOT located in the Caribbean with a population of c.15k located on an island of $35 \mathrm{sqm}$. There are, also, smaller unpopulated islands and cays.

${ }^{82}$ Bermuda (a former British Crown colony since 1684) is a self governing BOT located off the American coast with a population of $\mathrm{c} 71 \mathrm{k}$ located on an archipelago of 181 islands covering c. $21 \mathrm{sqm}$. It was also called the Somers islands and the Bermudas.

${ }^{83}$ The BVI (a former British Crown colony since 1960) is a self governing BOT located in the Caribbean with a population of c.35k located on 4 main islands and c. 50 smaller islands and cays (in all c. 16, are inhabited). It is also called the Virgin islands.

${ }^{84}$ The Cayman Islands (a former British Crown colony since 1962) is a self governing BOT located in the Caribbean with a population of $\mathrm{c}$. $66 \mathrm{k}$ located on 3 islands.

${ }^{85}$ The Falkland Islands (a former British Crown colony since 1840) is a self governing BOT located off the coast of South America with a population of c, 3.3k located on an archipelago of 2 main islands and 776 others covering 4,700 sqm. Its citizens are British citizens pursuant to the British Nationality (Falklands) Islands Act 1983.

${ }^{86}$ Gibraltar (ceded to Great Britain under the Treaty of Utrecht in 1813) is a self governing BOT located at the tip of Spain with a population of c. $32 \mathrm{k}$ located on a land mass of c. $6.7 \mathrm{sqm}$.

${ }^{87}$ Monserrat (a former British Crown colony since 1962) is a BOT with a large measure of self-governance located in the Caribbean with a population of c. $5 \mathrm{k}$ located on an island of c. $39 \mathrm{sqm}$.

${ }^{88}$ Pitcairn (a former British Crown colony since 1838) is a BOT with a measure of self government located in the South Pacific with a population of c. 45 comprising 4 islands (3 annexed in 1903, being Henderson, Oeno and Ducie) covering 18 sqm.

${ }^{89}$ There is a Governor only for Pitcairn. He may legislate but must consult first with the local island council. Hendry, n 65, p 10.

${ }^{90}$ St Helena (with Ascension and Tristan da Cunha) are all self governing islands located in the Atlantic. St Helena has a population of c, 4.4k (which have British citizenship). It was a Crown colony in 1833. Ascension (settled in 1815) has a (mainly non resident) population of c. 800 people and is an island of 34sqm. Tristan da Cunha (settled in 1810) has a population of c. 290 people and is an island of $293 \mathrm{sqm}$.

${ }^{91}$ There is a Governor only for Ascension and Tristan da Cunha. He may legislate but must consult first with the local island council. Hendry, n $56, \mathrm{p} 10$.

${ }^{92}$ The Sovereign Base Areas (SBA) are the areas mentioned in the Cyprus Act 1960, s 2(1), see 23. They cover c. 98 sqm (47.5 around Akrotiri and 50.5 around Dhekelia) and comprise military bases administered by the MOD.
} 
$56 \mathrm{k}$

Total: c. $371 \mathrm{k}$

BOT located in the Caribbean are in italics. ${ }^{94}$

\section{(d) Legal Regulation of BOT}

In the past, the legal regulation of colonies was conducted by the Crown, acting through the privy council - since it also dealt with the Channel Islands and the Isle of Man in this fashion. Such is reflected in, for example, the St Helena Act 1833, s 112 (Saint Helena vested in the Crown), still extant. It states:

The island of St Helena, and all forts, factories, public edifices, and hereditaments whatsoever in the said island, and all stores and property thereon fit or used for the service of the government thereof, shall be vested in [HM], and the said island shall be governed by such orders as [HM] in council [i.e. the privy council] shall from time to time issue in that behalf.

Today, as noted above, there is a large measure of self government with 9 BOT having their own legislatures. Even in those which do not - and have only a governor - the governor consults with the local island council prior to passing legislation. Thus, only in the BAT, BIOT, South Georgia, South Sandwich and the SBA can legislation be passed without local representation. Hendry (2018) summarised the position thus:

Each [BOT] has its own legislature, which enacts the great majority of laws for the territory. In the less populated territories the governor (or equivalent) is the legislature. In the nine territories there is an elected legislative body which debates and passes Bills and submits them for assent by the Queen or the governor on her behalf. Laws may also be made for the territories by UK Act of Parliament by Order in Council [OIC, i.e. by SI] made by $[\mathrm{HM}]$ on the advice of UK ministers, or by regulations made by a UK minister. ${ }^{95}$

Hendry also noted that each BOT had a distinct constitution, contained in an SI, of similarity in most cases. However, in 2 cases (Gibraltar and BIOT) the Crown has one by virtue of the exercise of the Crown prerogative. Further, the statutory power for others was not exclusive. Thus, he stated:

Each $[\mathrm{BOT}]$ has a distinct written constitution, designed to suit its circumstances...The constitution of each $[\mathrm{BOT}]$ is contained in an [OIC]. It is legally enacted by [HM], by and with the advice of her privy council, acting on the recommendation of UK ministers. But the legal basis for such [OIC] differs as between the various territories. At common law, the sovereign has prerogative power to establish a constitution for any of the territories. ${ }^{96}$ The prerogative remains the sole constituent power for Gibraltar and the [BIOT]. For all the other [BOT] territories there is a statutory constituent power, but in most cases that does not appear to have been treated as exclusive. The [OIC] providing constitutions for all except Anguilla and Bermuda recite not only the relevant statutory power but add words such as 'or otherwise in [HM] vested' or 'and all other powers enabling her to do so'. This suggests that the relevant statutes were not considered to have displaced the prerogative power entirely, or that some matters in the Orders required citation of prerogative powers. In any case the practice has been generally consistent. Even in the case of Anguilla and Bermuda, where the main constitution Orders recite only the relevant statutory powers, Orders amending them also recite other (unspecified) powers of [HM] ${ }^{97}$

In respect of statutory powers, Hendry refers to the following:

- $\quad$ British Settlements Acts 1887 \& 1945

- $\quad$ St Helena Act 1833

- $\quad$ Cyprus Act 1960

- West Indies Act 1962

- Bermuda Constitution Act 1967

- Anguilla Act 1980

- British Overseas Territories Act 2002

This legislation is considered later.

(e) Legal Regulation of BOT - Reform

The current method of legal regulation for BOT provides little transparency or accountability. Not least, because what Crown prerogatives exist with respect to BOT is so uncertain and opaque. Further, both the sovereign and

\footnotetext{
${ }^{93}$ The Turks and Caicos Islands (a former British Crown colony since 1962) is a self governing BOT in the Caribbean with a population of c. 56k. Its citizens are British citizens.

${ }^{94}$ As Hendry notes, $\mathrm{n} 56$, pp 1-2 'A few of the territories are the subject of continuing sovereignty disputes: the British Antartic Territory (with Argentina and Chile); the British Indian Ocean Territory (with Mauritius); the Falkland Islands and South Georgia and the South Sandwich Islands (with Argentina); and Gibraltar (with Spain).

${ }^{95}$ Hendry, n 56, pp 10-1. Also, ch 4.

${ }^{96}$ Ibid, p 14 cited Philip v Eyre (1870) LR 6 QB 1.

${ }^{97}$ Ibid, pp 14-5.
} 
the privy council only exercise a formal power. Thus, it should be clarified in a BTFRA as to the means by which BOT are to be legislatively provided for. And, what UK ministry is responsible. In conclusion, it is suggested that a BTFRA should provide for the following:

- $\quad$ UK Legislation or SI. A BTFRA should provide for the means of legislating for BOT to exclude the Crown prerogative (including legislating by means of a charter/letters patent). Also, legislating by way of colonial regulation should be excluded. ${ }^{98}$ Further, general legislation should be express, not implied.${ }^{99}$ Thus, the only modes for legislating for colonies should be by way of:

$$
\begin{aligned}
& \text { - UK general Acts; or } \\
& \text { - SI }
\end{aligned}
$$

The purpose of this is to make all BOT constitutions (and legislation) subject to the UK Parliament (not to the sovereign who, now, only exercises a formal role).

- $\quad$ Responsibility. A BTFRA should specify the FCDO as the primary ministry dealing with all BOT, save for the SBA where the MOD should be the primary ministry (since these comprise military bases). And, the Privy Council which for centuries has only had a formal role with 3 or 4 ministers (and the sovereign) simply rubber-stamping legal matters - should end. This, also, should ensure greater accountability and responsibility.

- Crown Prerogative - Constitutions. As Hendry notes, the Crown prerogative is the sole constituent power for Gibraltar and the BIOT (further, neither is within the British Settlements Acts 1887 and 1945, the real cause of the anomaly). The Crown prerogative is, also, referred to in some of the other BOT statutory constitutions as a sort of vague 'catch - all'. However, this leaves matters wholly opaque and anomalous. ${ }^{100}$ This anomaly (and lack of transparency) should be rectified by expressly providing that the UK may establish constitutions for any BOT by way of SI. And, that any Crown prerogative power to make BOT legislation is abolished. Further, scrutiny of constitutional SI should be made clear in a BTFRA. At present, there is inconsistency. ${ }^{101}$

\section{(f) BOT - Judicial System}

All BOT have their own courts system today. ${ }^{102}$ Thus, they have Superior Courts of First Instance (equivalent to the High Court). ${ }^{103}$ Also, magistrates' courts (save for the SBA). ${ }^{104}$ All, also, have a Court of Appeal. Thus,
- $\quad$ BAT
Supreme Court and Court of Appeal ${ }^{105}$
- Bermuda
Supreme Court and Court of Appeal ${ }^{106}$
- $\quad$ BIOT
Supreme Court and Court of Appeal ${ }^{107}$
- Caymans
Grand Court and Court of Appeal ${ }^{108}$
- Falklands
Supreme Court and Court of Appeal ${ }^{109}$
- Gibraltar
Supreme Court and Court of Appeal. ${ }^{110}$
- Pitcairn
Supreme Court and Court of Appeal ${ }^{111}$
- SBA
Resident Judge and Senior Judges Court (also acts as Court of Appeal) ${ }^{112}$
- $\quad$ Turks \& Caicos
Supreme Court and Court of Appeal ${ }^{113}$

\footnotetext{
${ }^{98}$ For the uncertain nature of colonial regulations (the current version is of 1977), see Hendry, n 56, pp 43-4 (who considers them out of date in some respects). Cf. UK Regulations which are not the same as colonial regulations.

${ }^{99}$ Cf. n 54

${ }^{100}$ Hendry, n 56, p 19 'The constitutions of two territories are contained in orders in council made exclusively by virtue of the royal prerogative. These are Gibraltar and the [BIOT]. The reason for this apparent anomaly is that, by contrast with the other territories, no Act of Parliament has been passed that deals with their constitutional arrangements. Neither territory is within the scope of the British Settlement Acts 1887 and 1945, because each was acquired by cession and thus falls outside the definition of 'British settlement' for the purpose of those Acts. In territories acquired by cession, as these two are, the Crown has full prerogative power to establish such legislative, executive and judicial arrangements as it thinks fit, and generally to act legislatively.'

${ }^{101}$ Ibid, n 56, p 20 who also noted 'Parliament has made little statutory provision for the scrutiny of its overseas territory constitutions.'

${ }^{102}$ Ibid, p 11 'Each territory has its own judicial system, with its own system of courts.'

${ }^{103}$ Ibid, p 114.

${ }^{104}$ Ibid, p 117.

${ }^{105}$ Courts established pursuant to an Order in Council. See Hendry, n 56, p 113.

${ }^{106}$ Established pursuant to the Bermuda Constitution Act 1967. See also Hendry, n 56, p 111.

${ }^{107}$ Established under the Crown prerogative, see Hendry, n 56, p 103.

${ }^{108}$ Established under the West Indies Act 1962.

${ }^{109}$ See also Hendry, n 56, p 111.

${ }^{110}$ Ibid, p 111.

${ }^{111}$ Established pursuant to an Order in Council.

${ }^{112}$ See Hendry, n 56, p 113. There are 2 SBA courts. Senior judges travel from the UK to hear more serious cases or appeals.

${ }^{113}$ Established under the West Indies Act 1962.
} 
- St Helena Supreme Court and Court of Appeal ${ }^{114}$

Some share a court system. Thus:

- Anguilla, Monserrat, BVI

- Falkland Islands

- St Helena share High Court (and Court of Appeal) of the East Caribbean Supreme Court.

the Falkland Islands Supreme Court (FISC) and Court of Appeal have jurisdiction in respect of South Georgian Islands. ${ }^{115}$ And, the FISC has jurisdiction re BAT.

the Supreme Court and Court of Appeal, ${ }^{116}$ also, act as the same for Ascension and Tristan da Cunha. ${ }^{117}$

All these courts can made a final appeal to the Judicial Committee of the Privy (the 'JCPC'). As to the power to establish courts in the BOT, this differs as Hendry notes. Thus, some have been established by virtue of the Crown prerogative; others by UK legislation; others by SI.

\section{(g) BOT - Judicial System - Reform}

Given the very small populations in BOT, one would suggest that reform cries out for some modernisation and streamlining - to save time and money for litigants. And, for those who pay for the court system.

- $\quad$ JCPC. A previous article has argued that the JCPC should be abolished and that its jurisdiction over British territories should pass to the UK Supreme Court. Not least, since its judges are the same. ${ }^{118}$ Such would get rid of much antiquated UK legislation governing the JCPC and streamline the UK court system.

- $\quad$ Appeals to JCPC. It may be appropriate to end any right to apply to the JCPC from Caribbean courts, leaving jurisdiction to be exercised, instead, by the Caribbean Court of Justice or by the East Caribbean Court of Appeal for all appeals (save possibly, to the JCPC/Supreme Court in respect of constitutional matters). Also, in any case, restricting appeals to the JCPC/Supreme Court greatly. That is, no appeals on criminal matters. And, appeals only where a JCPC/Supreme Court judge initially vets the application and determines that there is a civil or constitutional issue involved of 'great complexity or it is otherwise in the public interest for the Supreme Court to hear the case.' Otherwise, it robs the relevant BOT Appeal Courts of much of their efficacy.

- $\quad$ Amalgamate First Instant Courts. To speed up justice in the BOT (and reduce costs), perhaps, civil and criminal courts should be amalgamated into one High Court (that is, superior courts of first instance (howsoever called) are amalgamated into one High Court). Such would also enable the same to be in one building(s). ${ }^{119}$

- $\quad$ BAT, BIOT, Pitcairn, SBA. Since cases are (very) rare, would it not be better to abolish any Court of Appeal and allow application to a judge of the JCPC/Supreme Court, who may hear the same in England or in the Falklands? Also, is a Court of Appeal needed in the Falklands? Would an annual visit by a Supreme Court judge not be able to deal with any civil appeal as well as in Ascension and Tristan da Cunha? That is, in all these places just one High Court (dealing with civil and criminal matters) with an appeal to a Supreme Court (or Court of Appeal) judge who makes an annual (or bi-annual) visit.

In conclusion, the JCPC became an appeal court in Victorian times when colonies did not have such (or they were of dubious quality), Today, appeals to the JCPC (hopefully, now merged into the Supreme Court) should be rare (indeed, very rare). For example, if there are only 47 islanders in Pitcairn and they have a Court of First Instance and a Court of Appeal, do they really need to appeal to the JCPC/Supreme court on a regular basis? Or, is this a case of judicial overkill? (one marvels that fishing might be so hazardous in legal terms).

In conclusion, if all BOT had only a High Court and a Court of Appeal (or shared one) and the JCPC was merged into the Supreme Court, justice might be more expeditious and less costly.

\section{(h) BOT Governors}

In colonial times, UK officials were appointed by the Crown for the administration of colonies - such as governors, lieutenant governors, commissioners and administrators (as well as the Governor-General or Viceroy of India). Governors, commissioners and an administrator are still appointed for BOTs - though they tend to be local appointees these days. Chitty (writing in 1820) noted that:

They [the colonies established by charter] ${ }^{120}$ have a governor named by the king (or in some proprietary colonies, by the proprietor) who is his representative or deputy...The governors of colonies are in general invested with royal authority; they may call, prorogue, (adjourn) and dissolve the colonial assemblies, and exercise other kingly

\footnotetext{
${ }^{114}$ See Hendry, n 56, pp 111, 114.

${ }^{115}$ Established pursuant to an Order in Council. See Hendry, n 56, p 113.

${ }^{116}$ Established under the West Indies Act 1962. See also Hendry, n 65, p 111.

${ }^{117}$ Hendry, n 56, p 111

118 See McBain, n 1 (Courts).

${ }^{119}$ It seems the SBA has no magistrates' court. And, that there are no resident magistrates in St Helena, Ascension, Tristan da Cunha, Pitcairn, BIOT, BAT, South Georgia or the South Sandwich Islands. Further, the Falkland Islands senior magistrate, also, acts as such for Ascension. See generally, Hendry, n 56, p 118.

${ }^{120}$ The other two forms of colony, provincial establishments and proprietary government granted by the Crown to individuals, tended to die out.
} 
functions: but still they are but the servants or representatives of the king...And there can be no doubt that though the discretion in passing Acts of Parliament in England is an incommunicable prerogative, it is not so as to acts of assembly, but may be legally communicated to the governor of a colony. The same as to pardoning offenders in the colonies; though it is usual to except the cases of treason and murder. Nor can there be any doubt that the king may enable the governor to grant Crown lands, franchises, and possessions in colonies. The Acts of the governor should be under the great seal of the province, unless an usage $e$ contra can be shewn [shown]... But the powers of governors of colonies demand a more explicit statement. Every governor of a province, by his commission of captain general and governor in chief, and by his commission of vice admiral, and the instructions which accompany them, is vested with the following powers. ${ }^{21}$

Chitty then named 7 such powers, the governor:

- $\quad$ is captain general of land and sea forces with the power of appointment of all military officers;

- has the sole power of convening, adjourning, proroguing and dissolving the general assembly and may give (or refuse) his assent to any bill which has passed the council and assembly, as well as the disposal of offices as HM does himself dispose of;

- has custody of the great seal and is chancellor within his province, with the same powers of judicature that the Lord High Chancellor has in England;

- $\quad$ is ordinary within his province and by virtue of the king's commission, he collates to all vacant benefices, he has also the power of granting probate of wills and administration of intestate's effects, by virtue of his instructions;

- $\quad$ presides in the Court of Errors, of which he and the council are judges;

- $\quad$ is usually named first in the standing commission issued under 11 and 12 William 3 c 7 [Piracy Act 1698, rep 1993] for the more effectual suppression of piracy;

- $\quad$ is also vice-admiral within his province, but he does not sit in the court of vice admiralty, there being a judge of that court.

Since 1820 these powers (instructions) have become otiose in most respects. ${ }^{122}$ Also, with the ending of Crown colonies and their re-categorisation as BOT's, ended colonial categorisation. However, this has resulted in out dated and confusing terminology (see (m)). Hendry discusses the current status of a governor in his work in 2018. ${ }^{123}$ In some BOT, the title is that of a commissioner or an administrator, as opposed to a governor. There may also be acting or deputy governors. The sovereign appoints (usually, by royal commission) governors, but as advised by her UK ministers. Thus, in reality, the latter appoint and dismiss the same. Hendry noted:

While a variety of executive functions are conferred on governors by local legislation in a territory, and by Acts of Parliament or Orders in Council or Regulations that extend to a territory, some are typically found in the constitutions of the territories. ${ }^{124}$

In particular, Hendry referred to the following powers in respect of governors:

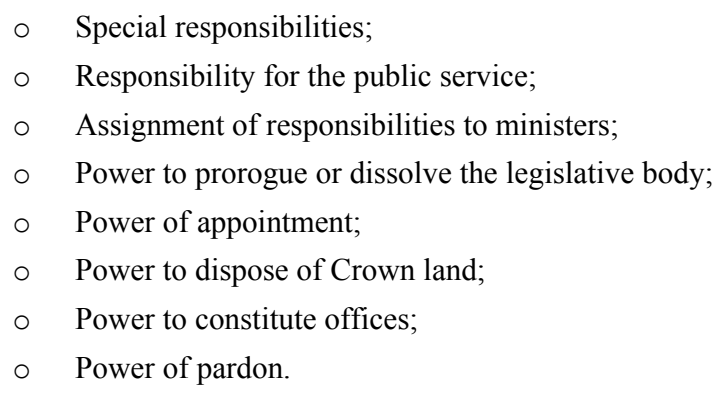

Governors also have functions in the legislative and judicial fields, as well as emergency powers.

\section{(i) BOT Governors - The Problem}

The problem of governors is that they are rather anachronistic today. Especially, in the case of 9 BOT with legislatures. Although formally appointed by the Crown, in reality, they are servants of the FCDO. Further, most governors do not have legal or judicial or military knowledge. Thus, it is better that any matters are left to experts. So too, in respect of the disposal of Crown land and the power to pardon. More importantly, in a democratic society with legislatures, it is local ministers (who are accountable to their electorate) who should be exercising many of these powers. Also, there is no real accountability to the UK Parliament, who should be oversighting

\footnotetext{
${ }^{121}$ Chitty, n $11, \mathrm{p} 35$.

${ }^{122}$ For the position by 1922, see Chalmers, n 15, pp 174-7. Also, Ridges (in 1934), n 17, pp 551-5. See also Halsbury, Laws, vol 6 (1909), p 372, para 545. Some BOT still have royal instructions, albeit, there are doubts about their legal effectiveness, see Hendry, $\mathrm{n} 56$, $\mathrm{p} 41$. As for instructions from UK ministers, G Marshall, Constitutional Conventions (1984), p 176, fn 8 (citing LS Amery, Thoughts on the Constitution ( $2^{\text {nd }}$ ed 1953)), p 7 'In the Dominions that authority... has in our time ceased to be exercised with reference to advice from the [SS] in London...'.

${ }^{123}$ See Hendry, n 56, ch 3.

${ }^{124}$ Ibid, p 44
} 
these things by means of the same being laid down in an SI. In short, the historical position has not really caught up with the $21^{\text {st }}$ century. Especially, transparency and accountability.

\section{(j) BOT Governors - Reform}

Today, with the greater need for accountability and transparency, it is suggested that:

- the legal powers of a governor (as well as a commissioner or administrator) for any BOT should be set out in a SI;

- $\quad$ any Crown instructions should be cancelled and any Crown prerogative to issue such (as well as Regulations) abolished (thereby, obviating problems for the sovereign and imposing accountability on the executive);

- $\quad$ any powers under the Crown prerogative with regard to the government of BOT should be abolished. In particular, to ensure judicial independence, any Crown prerogative of a governor to appoint a judge or other legal officer should now be exercised by a Judicial Services Commission - and neither the governor (nor the sovereign) be involved. ${ }^{125}$ Any Crown prerogative of a governor (commissioner or administrator) to:

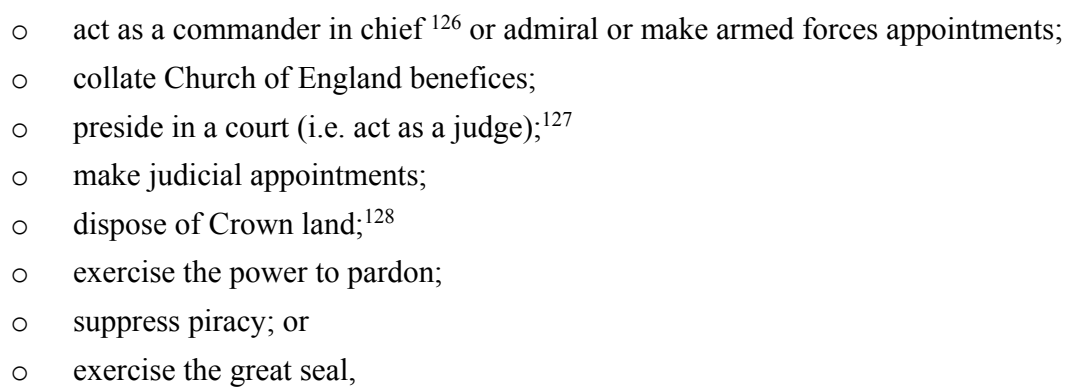

should be ended - since no governor is usually qualified for the same - save where a SI expressly so provides for a specific BOT such as the SBA. ${ }^{129}$

In conclusion, the role of a governor should one of direct appointment by the FCDO (or MOD). Even better if the same is a civil servant - ensuring accountability and excluding any allegation of partiality or cronyism. The role should be greatly slimmed down, so that local legislatures - and persons with the relevant expertise - are involved. Thus, the role should become more formal and, where executive power is exercised by a governor, local legislatures should expressly provide for the same. Thus, the nebulous and formal powers of the Crown are excluded, to the betterment of accountability and transparency.

\section{(k) BOT - Law Officers}

Hendry noted:

The law officers in the [BOT] are the principal legal advisers to the governments of the territories. There is, however, no single method of appointment of law officers in the territories, and nowadays their titles and number vary according to the needs and preferences of the territorial governments...In most of the [BOT] the Attorney General [the ' $\mathbf{A G}$ '] is the sole law officer, and some of the less populated territories have no resident [AG], relying instead on a non-resident $[\mathrm{AG}]$ or Legal Adviser for the government's legal advice. ${ }^{130}$

\section{$\underline{\text { BOT }}$}

Anguilla

Bermuda

\section{Attorney-General (AG)}

A-G

A-G. Also, DPP \& SG ${ }^{131}$

\footnotetext{
${ }^{125}$ That is, any appointment by letters patent or under the sign manual should be abolished.

${ }^{126}$ If a governor so acts (including making a declaration of martial law) such may be hazardous - especially in the case of loss of life. For $19^{\text {th }}$ century instances where declarations of martial law by governors proved disastrous, see GS McBain, Abolishing Obsolete Crown Prerogatives relating to Martial Law, Conscription and Billeting (2012) International Law Research, vol 1, no 1, pp 37-8. Today, assuming martial law is not obsolete and abolished, it is suggested it could only be imposed by UK Act of Parliament and not by a governor exercising the Crown prerogative (the effect of martial law is to permit trial of civilians by military tribunals and the ability to impose military punishments). If a civil uprising were to occur in a BOT and the local police (or militia) were unable to cope, it would seem better (legally) today for British troops (or those of the UN or another Caribbean county) to be called to assist (not least, since a member of the armed forces is entitled to apply, under English law, defensive measures commensurate with an attack on him, as the particular fact scenario demands). Certainly, the application of martial law in Victorian and later times (probably) caused greater casualties in colonies than might otherwise have eventuated. ${ }^{127}$ Hendry, n 56, p 49 'No governor has any judicial function in the overseas territories. But as the Queen's representative the governor is given powers to make judicial appointments.'

${ }^{128}$ To prevent misuse, impartiality etc, any disposal should be in a SI.

${ }^{129} \mathrm{Cf}$. Hendry, n 56, p 12 'The defence and security of the [BOT] is an important responsibility of the [UK]. For this reason these matters remain locally among the constitutional responsibilites of the governor. British armed forces are stationed in the Falkland Islands, Gibraltar, Ascension, the $[\mathrm{BAT}]$, the $[\mathrm{BIOT}]$ and the $[\mathrm{SBA}]$. Pursuant to various treaties, US armed forces are stationed on Ascension and on Diego Garcia in the $[\mathrm{BIOT}] . '$

${ }^{130}$ Hendry, n 56, p 133 .

${ }^{131}$ DPP stands for Director of Public Prosecutions, SG for Solicitor General (the deputy to the AG)
} 
British Antartic Territory (BAT)

British Indian Ocean Territory (BIOT)

British Virgin Islands (BVI)

Cayman Islands

Falkland Islands

Gibraltar

Monserrat

Pitcairn Islands

St Helena, Ascension \& Tristan da Cunha

South Georgia \& South Sandwich Islands

SBA of Akrotiri \& Dhekelia

Turks and Caicos Islands
A-G

Principal Legal Adviser \& General Counsel ${ }^{132}$

A-G. Also, DPP

A-G. Also, DPP \& SG

A-G

A-G

A-G. Also, DPP

NZ lawyer

A-G (acts for Ascension and Tristan da Cunha also)

A-G for Falklands

A-G and Legal Adviser

A-G. Also, DPP

As for the appointment of the same, Hendry notes:

In some constitutions the power to appoint the $[\mathrm{AG}]$ lies with the governor acting in his or her discretion, although there may be an additional requirement to obtain the approval of the Secretary of State. This tends to be in the smaller territories, sometimes where there is no public service commission. But the approach of giving the governor complete discretion in key appointments such as this is rather outdated and one which is now less common. In territories with a more sophisticated public appointments structure, an appointments commission is involved in the process of the appointment of the A-G. ${ }^{133}$

In terms of reform, it is suggested that the appointment (and dismissal) of all the above (AG, DPP and SG) not be left to the governor (or the sovereign), to prevent political involvement or any suggestion of partiality. Instead, the same should be by a Judicial and Legal Services Commission, whether located in the UK or otherwise. Further, the governor should not be involved in the dismissal of the same. Thus, a SI should set out the position for all these BOT officers as well as for their security of tenure and dismissal. So, too, the status of Queen's Counsel. ${ }^{134}$ Neither the governor (nor the sovereign) should be involved with the same. This, also, should be dealt with by a Judicial and Legal Services Commission.

In conclusion, any AG, DPP, SG or QC should be appointed by a Judicial and Legal Services Commission not the governor or the sovereign.

\section{(I) Original Status of BOT}

Hendry noted (2018):

Territories may be acquired by settlement, cession, conquest or annexation, or any combination of these two. Every territory must be assigned for the purposes of constitutional law, to one or other of these means of acquisition. This is a matter of law, and once assigned by practice or judicial decision this will not be disturbed by historical research. ${ }^{135}$

This is true. However, the purpose of this, today, tends to be very limited in that such may determine what (antiquated) colonial legislation may apply to it (see 9 et seq). If all this colonial legislation were repealed (with any section still needed being placed in a BTFRA) then (like the Channel Islands) the need to refer to early history in respect of each island for legal purposes would not be relevant. As it is, Hendry asserts the following:

Settled BOT. These comprise: Anguilla, Bermuda, Caymans, Falklands, Monserrat, Pitcairn, St Helena, Ascension, Tristan Da Cunha, Turks \& Caicos and BVI. Also, at least partly, South Georgia and the South Sandwich Islands. ${ }^{136}$ However, quixotically, the British Settlement Acts 1887 and 1945 (see 17) do not apply to most of these because of the limited definition in the 1887 Act, s 6; ${ }^{137}$

\footnotetext{
132 The same is, usually, based in the UK.

${ }^{133}$ Hendry, n 56, p 137

${ }^{134}$ Ibid, p 144 'Some law officers have been granted the honour of [QC] in their territories. It used to be the custom that the territory Law Officer was automatically made [a QC], but that has long ago ceased to be the case. Nowadays applications for silk must be made to the governor of the territory, whether by Law Officers, members of their chambers or members of the private legal profession practising in the territory. The governor consults the Chief Justice, and must seek approval by or on behalf of a Secretary of State. If an application is approved, the governor confers the status of [QC] on behalf of [HM].'

135 Ibid, p 7.

${ }^{136}$ Ibid 'A territory acquired by the Crown by settlement was a consequence of the fact of settlement by British subjects in a place where there was no population or no form of government considered civilised and recognised in international law.'

${ }^{137}$ Ibid, p 6 'Most of these territories are not treated as 'British settlements' for the purposes of the British Settlements Acts 1887 and 1945 , because of the special definition of that term in the 1887 Act. But that does not affect their classification as territories acquired by settlement.'
} 
Cession. These comprise: Gibraltar (from Spain) and BIOT (from France); ${ }^{138}$

Conquest. Today, there are no BOT save (Hendry asserts) the possible exception of the SBA. ${ }^{139}$

Annexation. This comprises the British Antartic Territory. Also, (in part) South Georgia and South Sandwich Islands. ${ }^{140}$ However, quixotically, the British Settlement Acts 1887 and 1945 do apply to these because of the (limited) definition in the 1887 Act, s 6 (see 17).

The solution to this (rather absurd) situation is to repeal outdated colonial legislation (including the Settlement Acts 1887 \& 1945) and provide in a BTFRA the net effect of the above (antiquated) categorisation - and to which BOT it still applies. As to the net effect, Hendy summarises it thus: He stated 'The matter of the acquisition of a territory matters in two main contexts.

The first relates to the power of the sovereign to legislate for the territory in exercise of the royal prerogative. At common law the sovereign had (at least initially) full prerogative power in relation to territories acquired by cession, conquest or annexation, but not in relation to territories acquired by settlement.

The second concerns the underlying law in force in a territory. Broadly speaking, in territories acquired by settlement, the settlers took with them the law of England as in force at the time of settlement, so far as applicable to their new situation, and this continued to apply until altered or replaced by later legislation. By contrast, in ceded or conquered territories, the law in force in the territory at the time of acquisition continued until altered or replaced by later legislation. ${ }^{141}$ (italics and bold supplied)

This legal approach is also antiquated and (one would suggest) out of touch with present realities. Thus, a BTFRA should apply a more realistic (and helpful) approach. One which respects democracy and the general right of local legislatures to lay down - and apply - their own law.

- $\quad$ Thus, a BTFRA should specify in them that English common law (or foreign law, as appropriate) applies to BOT as at the date of acquisition (which should be specified in the BTFRA) save as: (a) altered by local domestic legislation; or (b) where UK legislation expressly applies the same. This should apply to all of them.

The effect of this will be remedy inconsistencies (including the categorisation of various BOT). Since the Falklands has its own legislature, the jurisdiction of such should cover South Georgia and the South Sandwich islands (removing uncertainty, including the application of the Settlement Acts 1887 \& 1945). Further, if BIOT, $S B A$ and the British Antartic territories acquire a legislature, then, any domestic law of that legislature should, then, apply. In the meantime, it should be provided that English law applies.

\section{(m) Retained Outdated Nomenclature}

As Hendry noted, there is much old nomenclature (terminology) which does (or does not) apply to BOT and which simply confuses issues. Thus

- Dependent Territories. Hendry states 'It is no longer legally correct to describe [BOT] as 'dependent territories". One would agree since the intent of the British Overseas Territories Act 2002 was to do away with this. ${ }^{142}$

- $\quad$ Colony. The Interpretation Act 1978, Schedule defines such and (technically) this still covers BOT (at least, in Acts post-1889). ${ }^{143}$ However, much colonial legislation extant (see 9) is prior to this Act (and that of 1889). In any case, this term is no longer appropriate.

- Her Majesty's Dominions. This is not defined in legislation. Thus, its precise legal meaning is a matter of conjecture. The expression was used in the Statute of Westminster 1931 (extant) which legislation Hendry does not mention. ${ }^{144}$ Arguably, it only applies to the 6 dominions referred to in this Act (Canada, Australia, NZ, Irish Free State, Newfoundland and South Africa). This article argues for the repeal of the 1931 Act as spent and, in any case, the expression 'dominion' is not appropriate to apply, today, to any Commonwealth country, BOT or UK domestic territory. As Marshall noted, this term went out of use after 1947.145

\footnotetext{
${ }^{138}$ Ibid. 'A territory may be acquired by the Crown by cession under a treaty or agreement or by more informal means. Cession may be made by the government of a state or by the inhabitants.'

${ }^{139}$ Ibid. 'Some former territories were acquired by the Crown by conquest resulting from armed force.' Ibid, p 8 'Annexation was probably also the original basis for the acquisition of the territory comprising the [SBA], though it could be argued that Cyprus was acquired by cession or conquest.'

${ }^{140}$ Ibid 'Annexation of a territory describes the process of unilateral acquisition by the Crown in the absence of settlement, cession or conquest.'

${ }^{141}$ Ibid, $\mathrm{p} 8$.

${ }^{142}$ Hendry, n 56, p 3 referring to the explanatory notes to the 2002 Act. He regarded the term as outdated. Ibid, Preface. One would agree.

${ }^{143}$ Schedule 1 states 'Colony' means any part of [HM] dominions outside the British Islands [i.e. UK, Channel Islands, Isle of Man and Rockall] except: (a) countries having fully responsible status within the Commonwealth; (b) territories for whose external relations a country other than the [UK] is responsible; (c) associated states [there are none now]. However, 'colony' was only first defined in the Interpretation Act 1889. Thus, the position as to pre-1889 UK colonial legislation is unclear. Hendry regarded the term as outdated. Ibid, Preface. One would agree.

${ }^{144}$ Hendry, n 56, p 5.

${ }^{145}$ Marshall, n 122, p 168 'As a way of describing the fully independent Commonwealth countries the word 'Dominion' disappeared after the Second World War. ..The Dominions Office gave way in 1947 to the Commonwealth Relations Office, and at about the same time it was discovered that the name of the Dominion of Canada was simply "Canada".
} 
- British Possession. Pursuant to the definition in the Interpretation Act 1978, this includes anything outside the UK. Thus, it would include BOT. ${ }^{146}$

- $\quad$ British Islands. The Interpretation Act 1978 refers to the UK, the Channel Islands and Isle of Man. Thus, it does not include BOT. ${ }^{147}$ However, this expression is outdated and not appropriate today.

- Crown Dependency. This is (usually) referred to apply to the Channel Islands and the Isle of Man. ${ }^{148}$ However, the expression is not appropriate today. It does not appear to have a statutory basis either.

- Crown Colony. This was an older expression of uncertain import used to refer to certain colonies in the past. ${ }^{149}$ However, the expression is not appropriate today.

The solution, therefore, is for a BTFRA to repeal all colonial legislation still extant - which is what this article argues for. Also, a BTFRA to indicate that the above expressions shall no longer be used. Otherwise, confusion reigns.

\section{REFORM OF BOT - CONCLUSION}

(a) $\underline{\text { Reform }}$

Today, the sovereign (in person) exercises a formal role, as opposed to an executive one. Further, for the Crown in the body politic, the privy council - as previously noted - also, has long exercised only a formal role and has (long) been superceded by the Cabinet and ministries (including civil servants whose salaries are paid for by taxation). Keith (writing in 1940) put this neatly:

The extent of the foreign jurisdiction of the Crown is by statute placed wholly within the control of the Crown, through the Foreign or Colonial Secretary. The extent of British territory proper is declared by the Crown through the Home Secretary. ${ }^{150}$

In short, already by 1940 - some 80 years ago - any input by the sovereign or the privy council was pure rubber stamping and so it remains. Also - as with the Channel Islands and its relationship with the UK (on which the colonies were modelled in most instances) - all BOT, today, have a large measure of self-government save, possibly, for Pitcairn. Thus, they should be treated the same as the Channel Islands. The current, basic, problems relating to BOT from the legal perspective appear to be as follows:

- Crown Prerogatives. The exercise of Crown prerogatives should end - since it is so uncertain what prerogatives exist in respect of BOT (and, even in colonial times, they were uncertain). Thus, it is much better to re-state things in legislation. In this fashion the reality is indicated which is that the UK Parliament (not the Crown) in fact legislates for all territories, domestic and foreign, as the fons et origo (source) of governmental power over the same, which power is unlimited, this being an axiomatic, longstanding, legal proposition. ${ }^{151}$

- $\quad$ Privy Council. Its role with BOT should end. Instead, there should be a clear chain of accountability. Governors should be appointed by - and accountable to - the FCDO (or MOD) minister, who is accountable to the PM and to Cabinet, which is accountable to Parliament;

- $\quad$ Governors. These should be appointed (and dismissed) by the FCDO (or MOD) minister. Their powers should be set out in a SI (and standardised for all BOT, where possible). It would seem unnecessary that they hold (or be involved in) military or judicial functions. It would also seem better that governors are professional appointments emanating from the FCDO (or MOD), to insure professionalism and impartiality;

- $\quad$ Court System. Surely, such could be rationalised. And, the JCPC be excised from appeals for Caribbean countries, since there are, now, appropriate Caribbean courts. As for other BOT - if retained - then, the court should be the Supreme Court (not the JCPC) - and the right of appeal further restricted (else, it robs the local Appeal Courts of efficacy);

- $\quad$ Legislation. A BTFRA should provide that the means of legislating for BOT should be: (a) general legislation with express reference; and (b) SI. In the case of (a), UK legislation should apply to the BOT only when express and not

\footnotetext{
${ }^{146}$ Hendry, n 56, p 5. The Interpretation Act 1978 provides that a 'British possession' means 'any part of [HM's] dominions outside the [UK]; and where parts of such dominions are under both a central and a local legislature, all parts under the central legislature are deemed, for the purposes of this definition, to be one British possession.'

${ }^{147}$ Ibid. p, 7.

${ }^{148}$ Ibid, p 6.

${ }^{149} \mathrm{Ibid}, \mathrm{p} 5$ 'The term 'Crown colony' is sometimes informally used, but its precise meaning is unclear and it is therefore better avoided.' See also Walker, n 78 (Crown colony system). Also, Ridges (in 1934), n 17, p 544 (meaning of Crown colony).

${ }^{150}$ AB Keith, The Constitution of England from Queen Victoria to George VI (1940), vol 2, p 129.

${ }^{151}$ Hendry, n 56, p 22 'The most fundamental principle of the relationship between the overseas territories and the [UK] is the supremacy of Parliament. So, as a matter of constitutional law, Parliament has unlimited power to legislate for the overseas territories.' Unfortunately, reference to the 'Crown' (the legal fiction of the sovereign in the body politic) occludes this. Local government in the BOT (and Channel Islands and Isle of Man) is, ultimately, subject to Parliament which establishes such - including local legislatures. If the BOT do not want that, then, BOT are able to achieve another model such as a becoming a republic and/or securing Commonwealth status (eg. Canada etc). Also, Ridges (in 1934), n 17, p 549 'Every colony, whether a Crown colony or not, is subject to the paramount authority of the Imperial Parliament.' He provides various examples.
} 
when implied; ${ }^{152}$ (c) older UK legislation relating to BOT should be placed in a BTFRA. And, any SI consolidated; (d) express provision should be made that the UK is responsible for the foreign relations of BOT and for their defence.

In conclusion, a BTFRA should state that BOT comprise part of the overseas territories of the UK. And, that the UK ministry charged with the administration of the same is the FCDO (or MOD).

\section{(b) Great Potential of BOT ${ }^{153}$}

It may be that - in the past - government (and others) have viewed BOT as a somewhat anachronistic hangover from colonial days. However, one would suggest that they do have enormous potential. Some BOT already have marine zones, for the protection of the environment. Surely, these could be extended greatly? Especially, in respect of places such as BVI, the Falklands (including South Georgia and South Sandwich) and Pitcairn. Saint Helena now has an airport. Could airports and tourism be developed in other BOT?

\section{ROCKALL}

The island of Rockall, in the North Sea, is no different from other small inlands around the UK such as the isle of Lundy, St Kilda or the Isle of Wight save that they do not have general legislation dealing with them. ${ }^{154}$ All of such are parts of the UK and, despite being islands, they are no different from the mainland save where legislation may provide otherwise. Thus, legislation provides that Rockall is part of Scotland - the Island of Rockall Act 1972, still extant, $\mathrm{s} 1$ (incorporation of Rockall into the [UK] as part of the County of Inverness) stating:

As from the date of the passing of this Act, the island of Rockall (of which possession was formally taken in the name of [HM] on 18th September 1955 in pursuance of a Royal Warrant dated 14th September 1955 addressed to the Captain of [HM's] Ship Vidal) shall be incorporated into that part of the [UK] known as Scotland and shall form part of the Western Isles, and the law of Scotland shall apply accordingly.

Bradley (in 2018) noted:

The conduct of foreign affairs by the government is carried on mainly by reliance on the prerogative. The prerogative includes power to acquire additional territory; thus by royal warrant in 1955, the Crown took possession of the island of Rockall, subsequently incorporated into the [UK] as part of Scotland by the Island of Rockall Act 1972. It is doubtful whether the Crown may by treaty cede British territory without the authority of Parliament, and modern practice is to secure Parliamentary approval, ${ }^{155}$ but it seems that the prerogative includes power to declare or to alter the limits of British territorial waters. ${ }^{156}$

\section{This Act should be consolidated in a BTFRA.}

\section{INDEPENDENCE LEGISLATION}

After 1947 many former colonies and British India became independent, with most becoming part of the Commonwealth. ${ }^{157}$ There is a plethora of UK legislation relating to the same. However, this is fragmentary. In order to make this legislation more accessible - as well as to cut out further obsolete material - this should be consolidated in an Appendix to a BTFRA (to the extent not repealed). Such a consolidation will, also, ensure an easier comparison of extant wording. In particular, the following may be noted:

- $\quad \underline{\text { UK Legislation. }}$. All this material tends to exclude the application of the Colonial Laws Validity Act 1865 and the Colonial Courts of Admiralty Act 1890. This article suggests repeal of the same in any case (see 13 and 19). Also, the non-application of the Whaling Industry (Regulation) Act 1934. This could be more easily effected by a BTFRA stating such (i.e. no ship registered in any of the following States shall be treated as a 'British ship' with regard to any UK legislation).

- $\quad$ Sections relating to Independence. Consideration should be given to treating all this independence legislation as spent since the treating of these countries as independent - and the giving of initial constitutions for the same - has now long gone. Further, over time, draftsmen realised that it was better to avoid convoluted legislation such as that in the Statute of Westminster 1931 and provide for a separation of the UK from a former colony, by using short and simple language. Thus, it is appropriate to remove all the variants once and for all, by repealing all this legislation.

\footnotetext{
${ }^{152}$ Cf. n 54 .

${ }^{153}$ For other, general texts on BOT see: (a) A Young, Thin on the Ground, Land Resource Survey in British Overseas Territories (1007); (b) TW Keeble, Commercial relations between BOT and South America, 1806-1914: An Introductory Essay (1970); (c) D Thomas-James, Offshore Financial Centres and the Law: Suspect Wealth in BOT (2021); (d) Foreign Affairs Committee. $15^{\text {th }}$ Report, Global Britain and the BOT: Resetting the relationship. Report (House of Commons paper) HC 1464; (e) C Cawley, Colonies in Conflict: The History of the BOT (2015); (f) S McPherson, Britain's Treasure Islands: A Journey to the UK Overseas Territories (2016); (g) S Allen and C Monaghan, Fifty Years of the British Indian Ocean Territory: Legal Perspectives: 4 (2018); (h) C Parkinson, Bill of Rights and Decolonization: The Emergence of Human Rights Instruments in Britain's Overseas Territories (2017).

${ }^{154}$ See also Chitty, n 11, p 28.

${ }^{155}$ A fn referred to Anson, n 18, vol 2, ii, pp 137-42 and to Roberts-Wray, n 68, ch 4. It continued 'The Hong Kong Act 1985 provides that 'As from $1^{\text {st }}$ July $1997[\mathrm{HM}]$ shall no longer have or jurisdiction over any part of Hong Kong' (s 1(1).'

${ }^{156}$ A fn referred to $R v$ Kent $J J$, exp Lye [1967] 2 QB 153; c.f. WR Edeson (1973) 89 LQR 364.

${ }^{157}$ For background to the development of the Commonwealth, see V Bogdanor, The Monarchy and the Constitution (1997), ch 10.
} 
Then, the position of these former colonies and dominions will be the same as that the UK has with say, China or

Chile. No UK legislation applies to it unless there is express provision in a UK Act.

In conclusion, a BTFRA should consolidate independence legislation, excising obsolete material.

\section{COLONIAL LEGISLATION}

There is much antiquated Victorian legislation still extant which potentially, or actually, refers to UK territories. It comprises the following (together with the sections extant):

- $\quad$ Saint Helena Act 1833

$$
\begin{aligned}
& \text { s } 112 \\
& \text { ss 1, 3-5 } \\
& \text { s } 2 \\
& \text { ss } 1 \& 4 \\
& \text { ss } 1-6 \\
& \text { ss 1-2 } \\
& \text { ss } 1 \& 2,4-7 \\
& \text { ss 2-3 } \\
& \text { ss } 2-14 \\
& \text { ss 2-6 (and 1) } \\
& \text { ss } 1-13,16 \& 19 \\
& \text { ss 2-15 } \\
& \text { s } 1 \\
& \text { ss } 1-10 \\
& \text { s } 1 \\
& \text { ss 1-4, 6-7 } \\
& \text { ss } 3-5,7-8 \\
& \text { S } 1 \\
& \text { ss 1-6 }
\end{aligned}
$$$$
\text { S } 1
$$$$
\text { S } 1
$$

This legislation is now discussed. However, the thrust of the analysis is that such legislation is obsolete and should be repealed. Further, to the extent that it is not obsolete, it should be replaced by modern wording in a BTFRA since the above legislation deals with 'colonies' - a term now long past its 'sell-by' date since the process of decolonisation started post WWI (1914-8), more than 100 years ago. It may, also, be noted that modern legal texts, generally, ignore most of the above as spent or irrelevant. ${ }^{158}$ Other legislation of a greater order relates to the former dominions of Canada and Australia viz.

$$
\text { - } \quad \text { Canada Act } 1982
$$

These are considered in 27 and 28. As for the British Overseas Territories Act 2002 (which deals with the nationality of BOT citizens and the British Nationality Act 1981) will not be considered in this article since it is asserted that it does not need re-statement here (but in a new Nationality Act).

\section{COLONIAL LEGISLATION - ST HELENA ACT 1833}

This has already been referred to (see $\mathbf{5}(\mathbf{d})$ ). It should be re-stated in a BTFRA.

\section{COLONIAL LEGISLATION - COLONIAL AFFIDAVITS ACT 1859}

Despite colonies now being either BOT or independent, there is antiquated legislation still extant which should be repealed. Thus, the Colonial Affidavits Act 1859, s 2 (Power to colonial legislatures to repeal, alter, or amend provisions of recited Acts so far as applicable to such possessions) states:

It shall be lawful for the legislature or other legislative authority of any of [HM's] possessions abroad to which any of the provisions contained in the [New South Wales (Debts) Act 1813, 54 Geo 3 c 15 rep] ${ }^{159}$ or in the [Statutory Declarations Act 1835 , ss 15 (substitution of a declaration for an oath) and s 17 (submission on behalf of HM to be proved by a declaration)] shall apply, to repeal, alter, or amend all or any of the provisions, so far as applicable to such possession, in like manner and subject to the same conditions as if the same had been originally enacted by such legislature or legislative authority.

\footnotetext{
${ }^{158}$ See e.g. De Smith, Bradley and Barnett, see 2.

${ }^{159}$ This provided for land in the colony and dependencies New South Wales to be chargeable with debts (s 4). Thus, it has limited application.
} 
This section (indeed, Act) is no longer required since it does not apply to the Channel Islands or to the Isle of Man (which were - and are - not categorised as colonies). And, it cannot apply to colonies which are now independent - since they no longer comprise possessions or colonies - albeit, many belong to the Commonwealth. To the extent it might apply to BOT (which is uncertain) ${ }^{160}$ it is unnecessary for those 9 BOT with legislatures. In any case, the first Act referred to in s 2 (the NSW (Debts) Act 1813) has been repealed and the Statutory Declarations Act 1835, ss 15 is spent. Further, s 17 is not relevant today, such as to need application to a BOT vis-à-vis any repeal, amendment etc. These sections provide:

s 15 (Declaration substituted for oaths and affidavits required by 5 Geo. 2 c. 7. and 54 Geo. 3. c. 15)....In any action or suit brought or intended to be brought in any court of law or equity within any of the territories, plantations, colonies, or dependencies abroad, being within and part of [HM's] dominions, for or relating to any debt, or account, wherein any person residing in Great Britain and Ireland shall be a party, or for or relating to any lands, tenements, or hereditaments or other property situate, lying, and being in the said places respectively, it shall and may be lawful to and for the plaintiff or defendant, and also to and for any witness to be examined or made use of in such action or suit, to verify or prove any matter or thing relating thereto by solemn declaration or declarations in writing in the form in the schedule hereunto annexed, made before any justice of the peace, notary public, or other officer now by law authorized to administer an oath, and certified and transmitted under the signature and seal of any such justice, notary public duly admitted and practising, or other officer; which declaration, and every declaration relative to such matter or thing as aforesaid, in any foreign kingdom or state, or to the voyage of any ship or vessel, every such justice of the peace, notary public, or other officer shall be and he is hereby authorized and empowered to administer or receive; and every declaration so made, certified, and transmitted, shall in all such actions and suits be allowed to be of the same force and effect, as if the person or persons making the same had appeared and sworn or affirmed the matters contained in such declaration viva voce in open court, or upon a commission issued for the examination of witnesses or of any party in such action or suit respectively; provided that in every such declaration there shall be expressed the addition of the party making such declaration and the particular place of his or her abode.

In s 15, reference in the headnote is to 5 Geo 2 c 7 (Recovery of Debts in the American Plantations Act 1731 (rep)) and to the New South Wales (Debts) Act 1813 (54 Geo 3 c 15), rep. Thus, this section is spent.

$\mathrm{S} 17$ (Suits on behalf of [HM] to be proved by declaration). In all suits now depending or hereafter to be brought in any court of law or equity by or in behalf of [HM], in any of his said Majesty's territories, plantations, colonies, possessions, or dependencies, for or relating to any debt or account, [HM] shall and may prove his debts and accounts and examine his witness or witnesses by declaration, in like manner as any subject or subjects is or are empowered or may do by this present Act.

It is suggested that the above section, being a matter of civil procedure, is no longer required since local legislatures have (or are able) to make provision for the same.

\section{In conclusion, a BTFRA should repeal this legislation as obsolete.}

\section{COLONIAL LEGISLATION - ADMIRALTY OFFENCES (COLONIAL) ACTS $1849 \& 1860$}

(a) The 1849 Act

This Act contains the following sections:

$\mathrm{S} 1$ (All persons charged in any colony with offences committed on the sea, may be dealt with in the same manner as if the offences had been committed on waters within the local jurisdiction of the courts of the colony). If any person within any colony shall be charged with the commission of any treason, piracy, felony, robbery, murder, conspiracy, or other offence, of what nature or kind soever, committed upon the sea, or in any haven, river, creek, or place where the admiral or admirals have power, authority, or jurisdiction, or if any person charged with the commission of any such offence upon the sea, or in any such haven, river, creek, or place shall be brought for trial to any colony, then and in every such case all magistrates, justices of the peace, public prosecutors, juries, judges, courts, public officers, and other persons in such colony shall have and exercise the same jurisdiction and authorities for inquiring of, trying, hearing, determining, and adjudging such offences, and they are hereby respectively authorized, empowered, and required to institute and carry on all such proceedings for the bringing of such person so charged as aforesaid to trial, and for and auxiliary to and consequent upon the trial of any such person for any such offence wherewith he may be charged as aforesaid, as by the law of such colony would and ought to have been had and exercised or instituted and carried on by them respectively if such offence had been committed, and such person had been charged with having committed the same, upon any waters situate within the limits of any such colony, and within the limits of the local jurisdiction of the courts of criminal justice of such colony.

S 2. (Provision for the trial of murder or manslaughter, where the death only happens in the colony or upon the sea). Where any person shall die in any colony of any stroke, poisoning, or hurt, such person having been feloniously criminally stricken, poisoned, or hurt upon the sea, or in any haven, river, creek, or place where the admiral or admirals have power, authority, or jurisdiction, or at any place out of such colony, every offence committed in respect of any such case, whether the same shall amount to the offence of murder or of manslaughter, or of being accessory before the fact to murder, or after the fact to murder or manslaughter, may be dealt with, inquired of, tried, determined, and punished in such colony in the same manner in all respects as if such offence had been wholly committed in that colony; and that if any person in any colony shall be charged with any such offence as aforesaid in respect of the death of any person who having been feloniously criminally stricken, poisoned, or otherwise hurt, shall have died of such stroke, poisoning, or hurt upon the sea, or in any haven, river, creek, or place where the admiral or admirals have power, authority, or jurisdiction, such offence shall be held for the purpose of this Act to have been wholly committed upon the sea.

${ }^{160}$ See n 143. 
5 (Interpretation of terms). For the purposes of this Act the word "colony" shall mean any island, plantation, colony, dominion, fort, or factory of [HM], except any island within the [UK] and the islands of Man, Guernsey, Jersey, Alderney, and Sark, and the islands adjacent thereto respectively...

\section{(b) The 1860 Act}

The only extant section, s 1 (Legislatures of possessions abroad empowered to make ordinances enacting to the like effect as in provisions of $9 . G .4$ c. 31) states:

It shall be lawful for the legislature of any of [HM's] possessions abroad to enact by any law or ordinance, to be by them made in the usual manner, that where any person, being feloniously criminally stricken, poisoned, or otherwise hurt at any place within the limits of such possession, shall die of such stroke, poisoning, or hurt upon the sea or at any place out of the limits of such possession, every offence committed in respect of any such case, whether the same shall amount to the offence of murder or of manslaughter, or of being accessory before the fact to murder, or after the fact to murder or manslaughter, may be dealt with, inquired of, tried, determined, and punished in the possession within the limits of which such stroke, poisoning, or hurt shall happen, in the same manner in all respects as if such offence had been wholly committed within the limits of such possession; or such legislature may enact, by any such law or ordinance to be made as aforesaid, to the like effect (wording divided for ease of reference).

The ' 9 G 4 c 31 ' referred to is a reference to the Offences against the Person Act 1828 (mainly repealed by the Act of 1861 of the same name, and now repealed).

\section{(c) Repeal of Acts}

It is asserted that these Acts are no longer required since:

- $\quad$ they do not apply to the Channel Islands or to the Isle of Man (which were and are not categorised as colonies);

- they cannot, now, apply to colonies which are independent - since they are no longer possessions or colonies, albeit such may belong to the Commonwealth;

- to the extent they might apply to BOT (which is uncertain) ${ }^{161}$ this is unecessary for those 9 BOT with legislatures. Further, the International Protected Persons Act 1978 Act will have application in the case where the person stricken is a 'protected person' (the Head of State etc).

As for the other BOT, it is argued that the Settlement Act 1887 (see 17) would empower a BOT without a local legislature to enact such legislation or, if not, a BTFRA should indicate that English criminal law shall apply to such, save where local legislation applies (indeed, there is something of a gap (and uncertainty) as to the application of English criminal law generally to BOT).

\section{In conclusion, a BTFRA should repeal this legislation and enact a more modern provision, if required.}

\section{COLONIAL LEGISLATION - COLONIAL LAWS VALIDITY ACT 1865}

\section{(a) Wording of the Act}

This Act has the following the following extant sections:

S 1. (Definitions “Colony:” Legislature. Colonial Legislature: Representative Legislature: Colonial Law: Act of Parliament, \&c. to extend to colony when made applicable to such colony: Governor: Letters patent).

The term "colony" shall in this Act include all of [HMs] possessions abroad in which there shall exist a legislature, as herein-after defined, except the Channel Islands, the Isle of Man...

The terms "legislature" and "colonial legislature" shall severally signify the authority, other than the Imperial Parliament or [HM] in Council, competent to make laws for any colony:

The term "representative legislature" shall signify any colonial legislature which shall comprise a legislative body of which one half are elected by inhabitants of the colony:

The term "colonial law" shall include laws made for any colony either by such legislature as aforesaid or by [HM] in Council:

An Act of Parliament, or any provision thereof, shall, in construing this Act, be said to extend to any colony when it is made applicable to such colony by the express words or necessary intendment of any Act of Parliament: ${ }^{162}$

The term "governor" shall mean the officer lawfully administering the government of any colony:

The term "letters patent" shall mean letters patent under the Great Seal of the [UK] of Great Britain and Ireland.

$\mathrm{S} 2$. (Colonial law when void for repugnancy). Any colonial law which is or shall be in any respect repugnant to the provisions of any Act of Parliament extending to the colony to which such law may relate, or repugnant to any order or regulation made under authority of such Act of Parliament, or having in the colony the force and effect of such Act, ${ }^{163}$ shall be read subject to such Act, order, or regulation, and shall, to the extent of such repugnancy, but not otherwise, be and remain absolutely void and ${ }^{164}$ inoperative.

\footnotetext{
161 Ibid.

${ }^{162} \mathrm{Cf}$. $\mathrm{n}$ 54. It is suggested that an implied application is not appropriate today.

163 This wording is unclear and seems unnecessary.

${ }^{164}$ Cf. s 3 'void or inoperative'
} 
S 3. (Colonial law when not void for repugnancy). No colonial law shall be or be deemed to have been void or inoperative on the ground of repugnancy to the law of England, unless the same shall be repugnant to the provisions of some such Act of Parliament, order, or regulation as aforesaid. ${ }^{165}$

S 5 (Colonial legislatures may establish, \&c. courts of law. Representative legislature may alter constitution). Every colonial legislature shall have, and be deemed at all times to have had, full power within its jurisdiction to establish courts of judicature, and to abolish and reconstitute the same, and to alter the constitution thereof, and to make provision for the administration of justice therein; and every representative legislature shall, in respect to the colony under its jurisdiction, have, and be deemed at all times to have had, full power to make laws respecting the constitution, powers, and procedure of such legislature; provided that such laws shall have been passed in such manner and form as may from time to time be required by any Act of Parliament, letters patent, Order in Council, or colonial law for the time being in force in the said colony. ${ }^{166}$

Hendry asserts that this Act applies to all BOT. ${ }^{167}$ However, this Act is from 1865 and, thus, prior to 1889. Therefore, the position is not wholly certain. ${ }^{168}$ The important section tends to be $\mathrm{s} 2$ which gives law making local legislatures a virtual plenary power (including Gibraltar and BIOT). ${ }^{169}$ In particular, as Maitland noted (in 1887), s 2 only makes local legislation void as repugnant to a UK Act 'extending to the colony' 170 and few do. It is suggested that s 3 is superfluous and would not be contained in UK drafted legislation today.

\section{(b) $\underline{\text { Reform }}$}

This Act $^{171}$ should be repealed and, if required, re-stated in a BTFRA for the following reasons:

- $\quad$ Dominions. This Act applied to all 'colonies' which term also included 6 Crown self governing 'Dominions' viz. Canada, Australia, NZ, South Africa, the Irish Free State and Newfoundland. ${ }^{172}$ The Statute of Westminster 1931, s 2 dis-applied this 1865 Act. ${ }^{173}$

- $\quad$ Colonies now Independent States. This Act has also been dis-applied in respect of a large number of colonies that have become independent (see the legislation referred to in Appendix 1).

- $\quad$ BOT with Legislatures. To the extent it might apply to BOT (which is uncertain) ${ }^{174}$ this Act, s 5 was intended to apply only to colonies with representative legislatures (as defined) ${ }^{175}$ and there seem to be none such (i.e. with legislatures which comprise those with one half of the same elected by the inhabitants of the BOT as s 5 provides). ${ }^{176}$ Also, ss 4 and 6 would seem otiose in practice. If not, in any case, the Act employs antiquated wording (including reference to a 'colony'). Thus, a BTFRA should re-state its content (where required) in more modern terms. And,

\footnotetext{
${ }^{165}$ Section 4 is obsolete in practice. It states: 'S 4. (Colonial law not void for inconsistency with instructions). No colonial law passed with the occurrence of or assented to by the governor of any colony, or to be hereafter so passed or assented to, shall be or be deemed to have been void or inoperative by reason only of any instructions with reference to such law or the subject thereof which may have been given to such governor by or on behalf of $[\mathrm{HM}]$, by any instrument other than the letters patent or instrument authorizing such governor to concur in passing or to assent to laws for the peace, order, and good government of such colony, even though such instructions may be referred to in such letters patent or last-mentioned instrument.'

${ }^{166}$ Section 6 is of little modern relevance in practice. It states S 6 (Certified copies of laws to be evidence that they are properly passed. Proclamation to be evidence of assent and disallowance). The certificate of the clerk or other proper officer of a legislative body in any colony to the effect that the document to which it is attached is a true copy of any colonial law assented to by the governor of such colony, or of any Bill reserved for the signification of [HM's] pleasure by the said governor, shall be prima facie evidence that the document so certified is a true copy of such law or Bill, and, as the case may be, that such law has been duly and properly passed and assented to, or that such Bill has been duly and properly passed and presented to the governor; and any proclamation purporting to be published by authority of the governor in any newspaper in the colony to which such law or Bill shall relate, and signifying [HM's] disallowance of any such colonial law, or [HM's] assent to any such reserved Bill as aforesaid, shall be prima facie evidence of such disallowance or assent.'

167 'All [BOT] fall within the definition of 'colony' for the purposes of the Act. All the legislatures in or for the [BOT] described in this chapter fall within the definition of 'legislature' for the purposes of the Act. All laws made by any such legislature, as well as laws made for a territory by [OIC], are 'colonial laws' for the purposes of the Act'. Cf. Constitutions of Gibraltar and BIOT which are founded on Crown prerogative, Ibid, $\mathrm{p} 72$.

${ }^{168}$ See n 143.

${ }^{169}$ Hendry, n 56, p 73. One would agree.

${ }^{170}$ Maitland, $\mathrm{n} 13, \mathrm{p} 339$ 'The general rule is laid down by an act of $1865 \ldots$ every law made by a colonial legislature is valid for the colony except in so far as it is repugnant to any act of parliament extending to the colony. This gives the colonial legislatures liberal powers, for the number of acts of parliament which extend to the colonies is not very great.'

${ }^{171}$ For discussion see in particular, Hendry, n 56, pp 71-3, 81-2.

${ }^{172}$ Barnett, n 27, p 27 'In 1867, Canada became the first self-governing dominion (a status implying equality with rather than subordination to Britain), to be followed by Australia in 1900, New Zealand in 1907, South Africa in 1910 and the Irish Free State in 1921'.

${ }^{173}$ See McBain, n 1 (Parliament), p 159.

${ }^{174}$ See $n 143$.

${ }^{175}$ See Act, s 1. Halsbury, Laws (1909), vol 6, p 423, fn (q) 'the [Act] ...regulates the powers of colonial representative legislatures, the term 'representative legislature' signifies any colonial legislature which shall comprise a legislative body of which one half are elected by the inhabitants of the colony.'

${ }^{176}$ See Hendry, $\mathrm{n} 56, \mathrm{p} 30$. See also the additional problem as a result of the wording in constitutions of the BOT. Ibid, pp 30-1 and Chenard $v$ Arrisol [1949] AC 127.
} 
that such, also, applies to BOT presently without a legislature (effectively, replacing the British Settlement Acts 1887 and 1945, see 17).

In conclusion, a BTFRA should repeal this legislation as obsolete and, if required, re-state the same in a BTFRA. The only section (it is suggested) that may need to be re-stated is $\mathbf{s} 2$.

\section{COLONIAL LEGISLATION - COLONIAL MARRIAGES ACT 1865}

This Act has the following the following extant sections:

$\mathrm{S} 1$ (Operation of Colonial Laws establishing Validity of Marriages). Every law made or to be made by the legislature of any such possession as aforesaid for establishing the validity of any marriage or marriages contracted in such possession shall have and be deemed to have had from the making of such law the same force and effect for the purpose aforesaid within all parts of [HM's] dominions as such law may have had or may hereafter have within the possession for which the same was made: Provided, that nothing in this law contained shall give any effect or validity to any marriage, unless at the time of such marriage both of the parties thereto were, according to the law of England, competent to contract the same.

S 2 (Definition of 'legislature'). In this Act, the word 'legislature' shall include any authority competent to made laws for any of [HM's] possessions abroad, except the Parliament of the [UK] and [HM] in council (i.e. the privy council).

This Act provided for the recognition of marriages intra colonies (provided that there was also capacity under English law between the parties to the marriage). To the extent it might apply to BOT (which is uncertain) ${ }^{177}$ this Act would only apply to intra-recognition within the 9 BOT with legislatures (these being former colonial legislatures of 'dominions' - if the same are still categorised as such, see 13(b)). However, is it necessary? One would suggest not (it is, also, unclear whether there has ever been a case under this Act).

In conclusion, a BTFRA should repeal this legislation as obsolete. Or, if required, re-state the same in a BTFRA.

\section{COLONIAL LEGISLATION - COLONIAL PRISONERS REMOVAL ACT 1869}

(a) Wording of the Act

This Act has the following the following extant sections:

- $\quad$ s 2 (Definition of terms: Colony. Governor. Legislative body). For the purposes of this Act - The term "colony" shall not include any place within the [UK], the Isle of Man, or the Channel Islands... but shall include any plantation, territory, or settlement situate elsewhere within [HM's] dominions, and subject to the same local government; and for the purposes of this Act all plantations, territories, and settlements under a central legislature shall be deemed to be one colony under the same local government. ${ }^{178}$

S 4 (Prisoners may be removed from one colony to another for purposes of punishment). Any two colonies may, with the sanction of an order of [HM] in Council, agree for the removal of any prisoners under sentence or order of transportation, imprisonment, or penal servitude from one of such colonies to the other for the purpose of their undergoing in such other colony the whole or any part of their punishment, and for the return of such prisoners to the former colony at the expiration of their punishment, or at such other period as may be agreed upon, upon such terms and subject to such conditions as may seem good to the said colonies. ${ }^{179}$ (wording in italics is obsolete)

There are other extant sections, viz.

- $\quad \mathrm{S} 5$ deals with the removal of prisoners to be by warrant ${ }^{180}$ and it concerns removal by ship, this legislation being before the days of air transport;

- $\quad$ S 6 deems any prisoner removed to be in legal custody; ${ }^{181}$

\footnotetext{
${ }^{177}$ See n 143 .

${ }^{178}$ It continues "The term "governor" shall include the officer for the time being administering the government of any colony: The term "legislative body" shall mean any house of assembly or other body of persons having legislative powers in the colony, and where such body of persons consists of two separate houses it shall include both houses, and where there are local legislative bodies as well as a central legislative body shall mean the central legislative body only.'

${ }^{179}$ It continues 'The sanction of the order of [HM] in Council may be obtained, in the case of a colony having a legislative body, on an address of such body to [HM], and in the case of any colony not having a legislative body, on an address of the governor of such colony; and such sanction shall be in force as soon as such order in council has been published in the colony to which it relates. The agreement of any one colony with another shall for the purposes of this Act be testified by a writing under the hand of the governor of such colony.'

${ }^{180}$ (Removal of prisoners to be by warrant). 'Where the sanction of [HM] has been given to any such agreement as aforesaid relating to the removal of prisoners from one colony to another for the purpose of undergoing their punishment, any prisoners under sentence or order of transportation, imprisonment, or penal servitude may be removed from such one colony to the other under the authority of a warrant signed by the governor, and addressed to the master of any ship, or any other person or persons; and the person or persons to whom such warrant is addressed shall have power to convey the prisoner therein named to such other colony, and to deliver him when there into the custody of any authority designated in such warrant, or empowered by the governor of such last-mentioned colony to receive such prisoner.'

${ }^{181}$ (Prisoner in legal custody during removal). 'Every prisoner shall, from the time of his leaving his prison in one colony to the time of his reaching his prison in the other colony, be deemed to be in the legal custody of the person or persons empowered to remove him, and to be subject to the same restraint, and, in the event of misbehaviour, to the same punishment, as if he had continued in prison, and as if the person
} 
- $\quad$ S 7 relates to the liability of the prisoner removed. ${ }^{182}$

There is also a similar Act of 1884 (the Colonial Prisoners Removal Act 1884) with various sections still extant. These relate to prisoner removal (ss 2-9), criminal lunatics (s 10) and ss 11-4 (miscellaneous). They are not replicated here. ${ }^{183}$

\section{(b) Act no longer fit for Purpose}

This Act (and that of 1884) is long out of date. It never applied to the Channel Islands (until it was so applied by the Act of 1884, s 14) and it was prior to pre-independence days. Especially, when some (far flung) colonies had no (or inadequate) prisons. Or, where riots broke out or by reason of notoriety (such as in murder cases), for his safety or security, a prisoner was removed (by ship) from one colony to another.

- Today, given the territorial separation between BOT, the presence of prisons ${ }^{184}$ and air transport - if still required it would be much better for an SI to specify exactly when (and where) prisoners in one BOT can be moved to another or to the UK (and removal by air transport);

- Further, in respect of the 9 BOT which have their own legislatures, this Act is no longer appropriate in any case since they are now responsible for their own legal system (including courts and prisons and the retention of 'criminal lunatics' - again, not modern terminology). As for BOT without legislatures, many have no resident population (or, in the case of the SBA, they comprise military bases). ${ }^{185}$

In other words, it is better for such legislatures to deal with prisoner removal - including by way of a request for assistance, pursuant to a negotiated Mutual Assistance Agreement - with only those BOT that require such. In any case, an Agreement can be updated more easily rather than relying on this antiquated Act and the need to amend the same by UK general legislation. Indeed, amendment to the Repatriation of Prisoners Act 1984 to include all BOT that might be interested (as well as ad hoc agreements in extraordinary situations) would seem much better.

\section{In conclusion, a BTFRA should repeal this legislation as obsolete as well as that of 1884.}

\section{COLONIAL LEGISLATION - COURTS (COLONIAL) JURISDICTION ACT 1874}

This Act has the following extant sections:

S 2. (Definition of term "colony."). For the purposes of this Act, The term "colony" shall not include any places within the [UK], the Isle of Man. The Channel Islands, . . but shall include any plantation, territory, or settlement situate elsewhere within [HM's] dominions, and subject to the same local government; and for the purposes of this Act, all plantations, territories, and settlements under a central legislature shall be deemed to be one colony under the same local government. [wording in italics obsolete]

S 4. (At trials in any colonial courts by virtue of Imperial Acts, courts empowered to pass sentences as if crimes had been committed in the colony). When, by virtue of any Act of Parliament now or hereafter to be passed, a person is tried in a court of any colony for any crime or offence committed upon the high seas or elsewhere out of the territorial limits of such colony and of the local jurisdiction of such court, or if committed within such local jurisdiction made punishable by that Act, such person shall, upon conviction, be liable to such punishment as might have been inflicted upon him if the crime or offence had been committed within the limits of such colony and of the local jurisdiction of the court, and to no other, anything in any Act to the contrary notwithstanding: Provided always, that if the crime or offence is a crime or offence not punishable by the law of the colony in which the trial takes place, the person shall, on conviction, be liable to such punishment (other than capital punishment) as shall seem to the court most nearly to correspond to the punishment to which such person would have been liable in case such crime or offence had been tried in England. [wording in italics obsolete]

This Act does not apply to the Channel Islands or to the Isle of Man (as expressed). Nor to colonies now independent States (see Appendix 1). To the extent it might apply to BOT (which is uncertain) ${ }^{186}$ this Act should not apply to the 9 BOT with legislatures since they can create, or alter the nature of, crimes without regard to UK

or persons empowered to remove him were the gaoler or gaolers of such prison; and if he escape or attempt to escape from such custody, such prisoner, and every person aiding or attempting to aid him in such escape, shall be subject to the same punishment as if such escape or attempt to escape were an escape or attempt to escape from prison. A prison shall mean any place of confinement or any place where the prisoners undergo punishment. Any person punishable under this section may be tried and punished either in the colony from which the prisoner is being removed, or in the colony to which he is being removed; and the law applicable to such person shall be the law of the colony in which he is tried.'

${ }^{182}$ (Liability of prisoner in colony to which he is removed). 'Every prisoner shall, upon his delivery to the person having lawful authority to receive him in the colony to which he is removed, be subject within such colony to the same laws and regulations, and shall be dealt with in all respects in the same manner, as if he had been tried and received the same sentence in such colony as the sentence which has been passed on him in the colony from which he is removed.'

${ }^{183}$ See, generally, Hendry, n 56, pp 198-9.

${ }^{184}$ This is particularly important. Most BOT now have adequate prisons. Thus, the need to move prisoners to other BOT (or to the UK) is much less. Further, since BOT are so widely separated, removal to other BOT (or to the UK) would not be appropriate in many cases (e.g. moving a Pitcairn prisoner to the BIV). There are also human rights considerations, Hendry, n 65, p 200.

${ }^{185}$ The Repatriation of Prisoners Act 1984 applies to Pitcairn as well as to Anguilla, BAT, Caymans, Falklands, Monserrat, St Helena, Ascension, Tristan da Cunha and the SBA. See Hendry, n 56, pp 200-1. For extradition and anti-terrorism measures, see Hendry, n 56, pp 201-4.

${ }^{186}$ See n 143. 
legislation (Imperial Acts). To the extent that it may apply to other BOT, the same argument applies to the Admiralty Offences (Colonial) Act 1860, see 12.

\section{In conclusion, a BTFRA should repeal this legislation and enact a more modern provision, if required. 17. COLONIAL LEGISLATION - BRITISH SETTLEMENT ACTS $1877 \& 1945$}

\section{(a) Wording of the Act}

The 1887 Act contains the following extant sections:

s 2 (Power of the Queen in Council to make laws and establish courts). It shall be lawful for [HM] the Queen in Council [i.e. the privy council] from time to time to establish all such laws and institutions, and constitute such courts and officers, and make such provisions and regulations for the proceedings in the said courts and for the administration of justice, as may appear to [HM] in Council to be necessary for the peace, order, and good government of [HM's] subjects and others within any British settlement. ${ }^{187}$

S 4 (Power to the Queen in Council to confer Jurisdiction on certain Courts). It shall be lawful for [HM] in council [i.e. the privy council] to confer on any court in any British possession any such jurisdiction, civil or criminal, original or appellate, in respect of matters occurring or arising in any British settlement, and to make such provisions and regulations as [HM] in council may think fit respecting the exercise of the jurisdiction and conferred under this [s] on any court, and respecting the execution and enforcement and execution of the judgements and decrees, orders, and sentences of such court, and respecting appeals therefrom; and every order of $[\mathrm{HM}]$ in council under this [s] shall be effectual to vest in the court the jurisdiction expressed to be thereby conferred, and the court shall exercise the same in accordance with and subject to the said provisions and regulations. Provided always, that every order in council made in pursuance of this Act shall be laid before both Houses of Parliament as soon as conveniently may be after the making thereof.

S 5 (Making of Order in Council, \&c). It shall be lawful for [HM] the Queen in council from time to time to make, and when made to alter and revoke, Orders for the purposes of this Act.

S 6 (Definitions). For the purposes of this Act, the expression

'British possession' means any part of [HM's] possessions out of the [UK], and the expression

'British settlement' means any British possession which has not been acquired by cession or conquest, and is not for the time being within the jurisdiction of the legislature, constituted otherwise than by virtue of this Act or of any Act repealed by this Act, of any British possession. ${ }^{188}$

The courts have held the powers conferred in these Acts to be plenary. ${ }^{189}$

\section{(b) Application of Acts}

This term 'British settlement' never applied to the Channel Islands or to the Isle of Man. It also (as the 1887 Act expressly indicates) did not purport to apply to any colony not acquired by way of conquest or treaty. Thus, it could only apply to an uninhabited colony which was settled. Thus, Hendry stated:

These [the 1887 and 1945 Acts] are the statutory legal basis for the constitutions of the following territories: Ascension, [BAT], Falkland Islands, Pitcairn, South Georgia and the South Sandwich Islands, and Tristan da Cunha. Ascension and Tristan da Cunha are administered as a single territorial grouping with St Helena, so a single constitution governs all three, on the basis also of the power provided for by the St Helena Act $1833 .{ }^{190}$

\section{(c) Reform}

These Acts employ antiquated wording. So too, the St Helena Act 1833 . More importantly, there is no reason why the wider provisions of the Colonial Laws Validity Act 1865 Act (see 13) should not apply to these BOT. For example, the words 'for the peace, order, and good government' in s 2 comprise surplusage (for poetic effect, perhaps) in that they have no legal meaning which a court can seek to expound. ${ }^{191}$ Further, today, it should be obvious that the UK has authority to create courts (or to recognise them) as well as to make laws, since BOT (and colonies) are (and were) its territories. Thus, express provision for such in legislation (probably) was not necessary

\footnotetext{
${ }^{187}$ See also s 3 which is effectively obsolete in any case. S 3 (Delegation of power by the Queen) 'It shall be lawful for [HM] the Queen from time to time, by any instrument passed under the great seal of the [UK], or by any instructions under [HM's] royal sign manual referred to in such instrument as made or to be made, as respects any British settlement, to delegate to any three or more persons within the settlement all or any of the powers conferred by this Act on $[\mathrm{HM}]$ in Council, either absolutely or subject to such conditions, provisions, and limitations as may be specified in such instrument or instructions. Provided that, notwithstanding any such delegation, the Queen in Council may exercise all or any of the powers under this Act: Provided always, that every such instrument or instruction as aforesaid shall be laid before both Houses of Parliament as soon as conveniently may be after the making and enactment thereof respectively.'

${ }^{188}$ The British Settlements Act 1945, s 1 amends the Act of 1887 and provides that the 1887 Act shall have effect as if: (a) any reference therein to an instrument passed as aforesaid included a reference to a SI ((an order of $[\mathrm{HM}]$ in council). Also, that, for the reference therein to any 3 or more persons within the settlement there were substituted a reference to any specified person(s) or authority.

${ }^{189}$ Hendry, n 56, p 16.

${ }^{190} \mathrm{Ibid}, \mathrm{p} 15$.

${ }^{191}$ See Hendry, n 56, p 64 referring to R (Bancoult) v SS for Foreign and Commonwealth Affairs (no 2) [2008] UKHL 1 AC 453.
} 
in the Colonial Laws Validity Act 1865 and this Act in any case. ${ }^{192}$ Thus, a BTFRA should provide that a SI may, inter alia, provide for the following; any matter in respect of any BOT relating to:

(a) their constitution (and any variation, amendment or replacement thereof);

(b) any legislature;

(c) their government;

(d) the establishment of any court;

(e) the appointment and dismissal of a lieutenant governor, and the powers of the same;

(f) the imposition of any customs or common duty or tax;

$(\mathrm{g})$ any Crown property and hereditary revenues.

The validity of such a statutory provision in respect of all of these matters would seem axiomatic since BOT are territories of the UK. If BOT no longer wish to be they may, of course, seek independence. This axiom must also be seen in the context that the UK is obliged to provide defence and foreign relations for the BOT. Such should, also, be stated in a BTFRA. The above provision should also include the making of any incidental, consequential or transitional provisions as may appear to the FCDO necessary or expedient. It is suggested that such provision should, include:

- St Helena since the wording in the 1833 Act needs to be supplemented and there is no need for variation;

- the Caymans, Monserrat, Turks and Caicos and BVI (save where the SI would adapt or modify a local Act). The West Indies Act 1962 presently applies to these (see 24);

- Bermuda. The Bermuda Constitution Act 1967 presently applies (see 26);

- Anguilla. The Anguilla Act of 1980 presently applies (see 25);

- Gibraltar (their constitution is presently contained in a SI made under the royal prerogative) ${ }^{193}$

- $\quad$ BIOT (the same as Gibraltar). ${ }^{194}$

In short, a TRFA should set out - in modern terminology - the jurisdiction of the FCDO (and the MOD) with regard to all BOT. Further, reference to the sovereign in this should be excluded (as well as to the privy council) since the power of the same is formal only now. ${ }^{195}$ At present, the wording as to jurisdiction in respect of the various BOT is divergent and antiquated - being conducive only to litigation. ${ }^{196}$ Further, some SI are not required to be laid before the UK Parliament (i.e. those of Anguilla, Gibraltar, BIOT). Thus, there is no consistency and little accountability. It is suggested this is not appropriate in modern democratic society.

Further, at present, this can lead to rather strained legal analysis in seeking to always argue that each BOT must be treated distinctly. This may be so, in that they have different constitutions and courts. However, the approach to them generally must not be wholly individual; since such, then, leads to quixotic and case-by-case application and fragmentisation without any regard to the BOT as a whole. Also, BOT are territories of the UK and, thus, the $\mathrm{JCPC}^{197}$ and Supreme Court must have regard to an overall harmonisation of their law with that of the UK (with its component parts) and its domestic territories as well. As it is, the accumulated caselaw on BOT can only (charitably) be described as something of of a 'dog's dinner.' Such can be solved by a BTFRA repealing antiquated legislation (applicable in colonial times) and re-stating the effect of the caselaw in modern terms. Further, if a distinction is to be made, it should be drawn between those 9 BOT with legislatures and those without (where the ability to exercise UK government and rule should be plenary, i.e. not limited in any way).

In conclusion, a BTFRA should repeal this legislation, enacting more modern wording.

\footnotetext{
${ }^{192}$ Hendry, n 56, p 106 'the power to make constituent provision for a territory must necessarily include the power to establish courts'. See also quote of Roberts-Wray cited on that page.

193 Ibid, p 19.

194 Ibid, pp 19-20.

${ }^{195}$ Also, since this is a political process. Hendry, n 65, p 31 'An Order in Council amending, or evoking and replacing, a territory constitution is recommending to $[\mathrm{HM}]$ in draft by UK ministers. The Order itself is formally made by [HM] with the advice of her privy council. Apart from these final stages, there is no prescribed procedure. The practice in recent years has been, with very exceptions, to reach political agreement on the text of constitutional amendments, or of a new constitution, by negotiation between UK representatives and representatives of the territory concerned.' (italics supplied)

${ }^{196}$ Ibid, p 21

${ }^{197}$ The caselaw shows all the more reason to abolish the JCPC and merge it into the Supreme Court. Hendry, n 56. p 29 'Difficulty and confusion are likely to arise where the privy council and UK courts reach different conclusions on the same point of principle, as has sometimes happened, because each carries a different weight of authority in the territories and the [UK], respectively. But the risk of this occuring in serious cases should be reduced by the substantial overlap of judges sitting on the Supreme Court and the Privy Council. The importance of this from the legal standpoint of legal certainty is obvious.'
} 


\section{COLONIAL LEGISLATION - FOREIGN JURISDICTION ACTS 1890 \& 1913}

These Acts provide for the exercise by the Crown of extraterritorial jurisdiction. ${ }^{198}$

\section{(a) Wording of the Act}

This Act contains the following extant sections:

$\mathrm{S} 1$ (Exercise of jurisdiction in foreign country). It is and shall be lawful for [HM] the Queen to hold, exercise, and enjoy any jurisdiction which $[\mathrm{HM}]$ now has or may at any time hereafter have within a foreign country in the same and as ample a manner as if $[\mathrm{HM}]$ had acquired that jurisdiction by the cession or conquest of territory.

$\mathrm{S} 2$ (Exercise of jurisdiction over British subjects in countries without regular governments). Where a foreign country is not subject to any government from whom [HM] the Queen might obtain jurisdiction in the manner recited by this Act, [HM] shall by virtue of this Act have jurisdiction over [HM's] subjects for the time being resident in or resorting to that country, and that jurisdiction shall be the jurisdiction of $[\mathrm{HM}]$ in a foreign country within the meaning of the other provisions of this Act.

S 3 (Validity of acts done in pursuance of jurisdiction). Every act and thing done in pursuance of any jurisdiction of [HM] in a foreign country shall be as valid as if it had been done according to the local law then in force in that country.

S 4 (Evidence as to existence or extent of jurisdiction in foreign country). If in any proceeding, civil or criminal, in a court in [HM's] or held under the authority of [HM] any question arises as to the existence or extent of any jurisdiction of [HM] in a foreign country, a Secretary of State [SS] shall, on the application of the court, send to the court within a reasonable time his decision on the question, and his decision shall for the purposes of the proceeding be final. ${ }^{199}$

S 5 (Power to extend enactments in First Schedule). (1) It shall be lawful for [HM] the Queen in Council, if She thinks fit, by Order to direct that all or any of the enactments described in the First Schedule to this Act, or any enactments for the time being in force amending or substituted for the same, shall extend, with or without any exceptions, adaptations, or modifications in the Order mentioned, to any foreign country in which for the time being [HM] has jurisdiction. ${ }^{200}$

S 6 (Power to send persons charged with offences for trial to a British possession). (1)Where a person is charged with an offence cognizable by a British court in a foreign country, any person having authority derived from [HM] in that behalf may, by warrant, cause the person so charged to be sent for trial to any British possession for the time being appointed in that behalf by [OIC], and upon the arrival of the person so charged in that British possession, such criminal court of that possession as is authorised in that behalf by [OIC], or if no court is so authorised, the supreme criminal court of that possession, may cause him to be kept in safe and proper custody, and so soon as conveniently may be may inquire of, try, and determine the offence, and on conviction punish the offender according to the laws in force in that behalf within that possession in the same manner as if the offence had been committed within the jurisdiction of that criminal court. ${ }^{201}$

S 7 (Provision as to place of punishment of persons convicted). Where an offender convicted before a British court in a foreign country has been sentenced by that court to suffer death, penal servitude, imprisonment, or any other punishment, the sentence shall be carried into effect in such place as may be directed by [OIC] or be determined in accordance with directions given by [OIC], and the conviction and sentence shall be of the same force in the place in which the sentence is so carried into effect as if the conviction had been made and the sentence passed by a competent court in that place. (words in italics are obsolete)

S 8 (Validity of acts done under Order in Council). Where, by [OIC] made in pursuance of this Act, any British court in a foreign country is authorised to order the removal or deportation of any person from that country, that removal or deportation, and any

\footnotetext{
${ }^{198}$ For discussion of Foreign Jurisdiction Act 1843-78, see Amos, n 73, pp 187-9.

${ }^{199}$ It continues: '(2) The court shall send to the [SS], in a document under the seal of the court, or signed by a judge of the court, questions framed so as properly to raise the question, and sufficient answers to those questions shall be returned by the [SS] to the court, and those answers shall, on production thereof, be conclusive evidence of the matters therein contained.'

${ }^{200}$ It continues: '(2) Thereupon those enactments shall, to the extent of that jurisdiction, operate as if that country were a British possession, and as if $[\mathrm{HM}]$ in Council were the legislature of that possession.' The Schedule to this Act referred to the Admiralty Offences (Colonial) Act 1849, Evidence Act 1851 (ss 7 \& 11), British Law Ascertainment Act 1859, Admiralty Offences (Colonial) Act 1860, The Conveyancing (Scotland) Act 1874, s 51, The Merchant Shipping Act 1995. A similar Act of 1913 applied the Colonial Prisoners Removal Act 1869, The Colonial Probates Act 1892 and the Colonial Solicitors Act 1900.

${ }^{201}$ It continues: 'Provided that- (a) A person so charged may, before being so sent for trial tender for examination in a British court in the foreign country where the offence is alleged to have been committed any competent witness whose evidence he deems material for his defence and whom he alleges himself unable to produce at the trial in the British possession: (b) In such case the British court in the foreign country shall proceed in the examination and cross-examination of the witness as though he had been tendered at a trial before that court, and shall cause the evidence so taken to be reduced into writing, and shall transmit to the criminal court of the British possession by which the person charged is to be tried a copy of the evidence, certified as correct under the seal of the court before which the evidence was taken, or the signature of a judge of that court: (c) Thereupon the court of the British possession before which the trial takes place shall allow so much of the evidence so taken as would have been admissible according to the law and practice of that court, had the witness been produced and examined at the trial, to be read and received as legal evidence at the trial: (d) The court of the British possession shall admit and give effect to the law by which the alleged offender would have been tried by the British court in the foreign country in which his offence is alleged to have been committed, so far as that law relates to the criminality of the act alleged to have been committed, or the nature or the degree of the offence, or the punishment thereof, if the law differs in those respects from the law in force in that British possession.' (2) Nothing in this [s] shall alter or repeal any law, statute, or usage by virtue of which any offence committed out of [HM's] dominions may, irrespectively of this Act be inquired of, tried, determined, and punished within [HM's] dominions, or any part thereof.'
} 
detention for the purposes thereof, according to the provisions of the [OIC], shall be as lawful as if the order of the court were to have effect wholly within that country.

$\mathrm{S} 9$ (Power to assign jurisdiction to British courts in cases within Foreign Jurisdiction Act). It shall be lawful for [HM] the Queen in Council, by Order, to assign to or confer on any court in any British possession, or held under the authority of [HM], any jurisdiction, civil or criminal, original or appellate, which may lawfully by [OIC] be assigned to or conferred on any British court in any foreign country, and to make such provisions and regulations as to [HM] in Council seem meet respecting the exercise of the jurisdiction so assigned or conferred, and respecting the enforcement and execution of the judgments, decrees, orders, and sentences of any such court, and respecting appeals therefrom.

S 10 (Power to amend Orders in Council). It shall be lawful for [HM] the Queen in Council to revoke or vary any [OIC] made in pursuance of this Act.

S 11 (Laying before Parliament, and effect of Orders in Council). Every [OIC] made in pursuance of this Act shall be laid before both Houses of Parliament.

S 12 (In what cases Orders in Council void for repugnancy).(1) If any [OIC] made in pursuance of this Act as respects any foreign country is in any respect repugnant to the provisions of any Act of Parliament extending to [HM's] subjects in that country, or repugnant to any order or regulation made under the authority of any such Act of Parliament, or having in that country the force and effect of any such Act, it shall be read subject to that Act, order, or regulation, and shall, to the extent of such repugnancy, but not otherwise, be void. (2) An [OIC] made in pursuance of this Act shall not be, or be deemed to have been, void on the ground of repugnancy to the law of England unless it is repugnant to the provisions of some such Act of Parliament, order, or regulation as aforesaid.

S 13. (Provisions for protection of persons acting under Foreign Jurisdiction Acts). (1) An action, suit, prosecution, or proceeding against any person for any act done in pursuance or execution or intended execution of this Act, or of any enactment repealed by this Act, or of any [OIC] made under this Act, or of any such jurisdiction of [HM] as is mentioned in this Act, or in respect of any alleged neglect or default in the execution of this Act, or of any such enactment, [OIC], or jurisdiction as aforesaid, shall not lie or be instituted - (a) in any court within [HM's] dominions, unless it is commenced within six months next after the act, neglect, or default complained of, or in case of a continuance of injury or damage within six months next after the ceasing thereof, or where the cause of action arose out of [HM's] dominions within six months after the parties to the action, suit, prosecution, or proceeding have been within the jurisdiction of the court in which the same is instituted; nor (b) in any of [HMs] courts without [HM's] dominions, unless the cause of action arose within the jurisdiction of that court, and the action is commenced within six months next after the act, neglect, or default complained of, or, in case of a continuance of injury or damage, within six months next after the ceasing thereof.

S 16 (Definitions). In this Act, - The expression "foreign country" means any country or place out of [HM's] dominions: ${ }^{202}$ The expression "British court in a foreign country" means any British court having jurisdiction out of [HM's] dominions in pursuance of an [OIC] whether made under any Act or otherwise: The expression "jurisdiction" includes power.

\section{(b) Act Obsolete}

The Foreign Jurisdiction Act 1890 (as well as that of 1913) was intended to extend the jurisdiction of the Crown to foreign countries or countries which had no regular government or appropriate courts. ${ }^{203}$ Thus, Chalmers (in 1936) stated:

in the case of barbarous countries, or countries where there is no regular government, foreign jurisdiction is exercised on a much more extensive scale, and its exercise is regulated by the Foreign Jurisdiction Act, 1890, which begins by reciting that by treaty, capitulation, grant, usage, sufferance and other lawful means, the Crown has jurisdiction within divers foreign countries. The Act then proceeds to empower persons authorised by warrant from the Crown to send for trial, at some specified court, persons charged with offences in the particular foreign country named. It also authorises the Crown, by Order in Council, to create courts of civil and criminal jurisdiction in the foreign country and to regulate the procedure of these courts, and to define the persons who should be subject to their jurisdiction. For example, consular courts of civil and criminal jurisdiction have been created in Persia by an order of council of 1889 . So, too, consular courts have been created in Morocco, with a curious concurrent and appellate jurisdiction in the Supreme Court at Gibraltar. ${ }^{204}$

In particular, this Act was intended to deal with protectorates - such as the former African Protectorates of Bechuanaland and Swaziland, the Federated and Unfederated Malay States, Sarawark, Tonga, Zanzibar etc. This Act also made provision for the establishment of consular courts in countries which otherwise had no courts (or no appropriate courts), this pursuant to a treaty or grant with a foreign country. Wade (writing in 1931) stated:

Protectorates are not part of the British Empire. They are territories not yet fully settled, or territories in which by treaty or the consent (sometimes enforced) of native rulers the inhabitants have accepted British protection and whose foreign relations are guided by Great Britain. The inhabitants of a protectorate do not become British subjects ...Protectorates are foreign countries and the Crown legislates for these under the Foreign Jurisdiction

\footnotetext{
202 Thus, this Act excludes BOT (colonies).

${ }^{203}$ See generally, Halsbury, Laws, vol 6, p 448.

${ }^{204}$ Chalmers. n 15, p 391. These consular courts no longer exist.
} 
Acts, 1890 and 1913, just as though the protected territory had been acquired by conquest or cession as part of the dominions of the Crown. The principal African protectorates are governed as colonies with constitutions established by orders in council....The Foreign Jurisdiction Act, 1890, provides also for the exercise by the Crown of jurisdiction by [i.e. in] foreign countries acquired through treaty or grant. Such jurisdiction is exercised in civilised countries through consular or similar courts. ${ }^{205}$

No British protectorates now exist. Nor consular courts. ${ }^{206}$ Further, it should be noted that this Act does not apply to British citizens in the $\mathrm{BOT}^{207}$ or the Channel Islands (or Rockall) but to those in a 'foreign country'. It, also, pre-dates the establishing of mandated territories after WW1 and WW2. It is asserted that the establishment of a British court in a foreign country today is a matter which should only be effected with the consent of Parliament - with specific provision being made in legislation. In short, this Act is obsolete given the absence of any protectorates or foreign countries in which it would be appropriate to establish by treaty or grant a British court (in any case, s 5 is obsolete as are, effectively, ss $6 \&$ 7). Finally, modern legislation would be appropriate to deal with such a contingency.

In conclusion, this Act should be repealed as obsolete since there are no British protectorates or foreign countries in respect of jurisdiction, to which it applies. Today, express legislative provision would, in any case, be appropriate.

\section{COLONIAL LEGISLATION - COLONIAL COURTS OF ADMIRALTY ACT 1890}

This Act (ss 2-15) has been considered in a previous article. ${ }^{208}$ It did not (and does not) apply to the Channel Islands nor to the Isle of Man. And, it cannot now apply to colonies which are independent countries - since they are no longer colonies, albeit, many belong to the Commonwealth. As for BOT, Hendry notes:

[S] 2 confers on a colonial court of admiralty the same jurisdiction as the High Court of Justice in England, with qualifications, but this was held to refer to the High Court's jurisdiction as in 1890. Orders in Council made under [s] 150 of the Supreme Court Act 1981 may extend the jurisdiction of colonial courts of admiralty to the full admiralty jurisdiction conferred on the High Court by that Act. Such orders were made under the Administration of Justice Act 1956, which now have effect as if made under [s] 150 of the 1981 Act, in respect of Anguilla, the Cayman Islands, The Falkland Islands, Monserrat, St Helena, Ascension and Tristan da Cunha, the Turks and Caicos Islands, and the Virgin Islands. ${ }^{209}$

This method of application is somewhat convoluted and not very helpful. It also does not deal with other BOT. Since all BOT now have civil courts, then, it would useful for a BTFRA to repeal this legislation and to provide that every BOT civil court shall have admiralty jurisdiction as an incident of the same or as otherwise provided in its legislation. In may be noted that, today, all BOT have a civil court.

\section{In conclusion, a BTFRA should repeal this legislation, making modern provision.}

\section{COLONIAL LEGISLATION - COLONIAL BOUNDARIES ACT 1895}

This Act contains an extant s 1(1) which provides:

Where the boundaries of a colony have, either before or after the passing of this Act, been altered by [HM] the Queen by [OIC] or letters patent the boundaries as so altered shall be, and be deemed to have been from the date of the alteration, the boundaries of the colony.

Today, boundaries have been altered by SI, as Hendry noted. ${ }^{210}$ Thus, this section, which is useful should be modernised in a BTFRA (the reference to a 'colony' and the alternative of 'letters patent' are no longer appropriate). It should also make it clear that a SI may alter the boundaries of all BOT.

\section{In conclusion, a BTFRA should provide modern wording and repeal this legislation.}

\section{STATUTE OF WESTMINSTER 1931}

This legislation has been considered in a previous article on a Parliament Act. ${ }^{211}$ It applied only to Canada, Australia, NZ, the Irish Free State and Newfoundland, enabling these dominions to exercise sovereign powers of amendment over their own constitutions. ${ }^{212}$

\footnotetext{
${ }^{205}$ Wade, n 16, pp 369-71. See also Keith (writing in 1940), n 150, pp 148-9 'The former system, by which the Crown was accorded jurisdiction over British subjects and British protected persons in certain foreign countries by consent of the sovereign, has been in steady decline in recent years.'

${ }^{206}$ A useful list is contained in Ridges (in 1934), n 17, pp 564-77. It may be noted that consular courts were much resented in foreign countries such as China and Korea as being exorbitant.

${ }^{207}$ Halsbury, Statutes ( $4^{\text {th }}$ ed), vol 10(1) does not make this clear. Cf. Hendry, n 56, p 6.

${ }^{208}$ See McBain, n 1 (Courts), p 230.

${ }^{209}$ Hendry, n 56, p 107.

${ }^{210}$ Ibid, p 9. See also p 312.

211 See McBain, n 1 (Parliament)

${ }^{212}$ Marshall, n 122, p 172 'A crucial turning point was the Statute of Westminster in 1931 which gave legal force to the convention of equal status, empowering Australia, Canada, New Zealand, the Irish Free State, and South Africa to exercise sovereign powers of amendment over
} 
For the reason given in that article it should be repealed including s 4 (UK Parliament not to legislate for Dominion except by consent) since such is unnecessary (these countries have competence to self-legislate, if so minded, on any matter on which they might request the UK to legislate). As for the preamble to this Act, it is unclear whether such was ever intended to have legal effect. Generally, preambles to UK legislation do not. However, to the extent it does, it, also, should be repealed since it is no longer observed as to the title accorded to the sovereign ${ }^{213}$ and its application in respect of the religion of the sovereign would seem to be a matter for the competence of the UK legislature to now determine. ${ }^{214}$

In conclusion, a BTFRA should repeal this legislation as obsolete (for Australia, see 28).

22. COLONIAL LEGISLATION - MANDATED TRUST TERRITORIES ACT 1947

This Act contains s 1 extant which relates to the application and modification of enactments. However, it is spent since, presently, there are no British mandated trusts (nor other UN trust territories) and there have not been for a long time. ${ }^{215}$

In conclusion, a BTFRA should repeal this legislation as obsolete.

23. COLONIAL LEGISLATION - CYPRUS ACT 1960

Extant sections of this Act comprise the following:

$\mathrm{S} 1$ (Establishment of the Republic of Cyprus ['ROC'] as an independent sovereign country). [HM] may by Order in Council [OIC] to be laid before Parliament after being made) declare that the constitution designated in the Order as the Constitution of the ROC shall come into force on such day as may be specified in the Order; and on that day there shall be established in the Island of Cyprus an independent sovereign ROC, and [HM] shall have no sovereignty or jursidiction over the [ROC].

S 2 (The Sovereign Base Areas). (1) The ROC shall comprise the entirety of the Island of Cyprus with the exception of the two areas defined as mentioned in the following [ss], and - (a) nothing in the foregoing [s] shall affect [HM's] sovereignty or jurisdiction over those areas; (b) The power of [HM] to make or provide for the making of laws for the said areas shall include power to make such laws (relating to persons or things either within or outside the areas) and such provisions for the making of laws (relating as aforesaid) as appear to [HM] requisite for giving effect to arrangements with the authorities of the [ROC]. (2) The boundaries of the said areas shall, subject to the provisions of this [s], be those defined by the maps, photographs and descriptive matter, authenticated by the signature of the Secretary of State ['SS'] which have been deposited at the Commonwealth Relations Office and presented to Parliament by the [SS] by Command of [HM]. (3) If [HM] by [OIC] declares that arrangements have been made - (a) for the demarcation of the said boundaries by two or more Commissioners appointed as specified in the arrangements; (b) for the determination, in default of agreement between the Commissioners, of any question as to the interpretation of the maps, photographs or descriptive matter; and (c) for the variation of the boundaries, as defined by the maps, photographs and descriptive matter, by agreement between the Commissioners where it appears to them expedient to do so on any grounds specified in the arrangements, and that the Commissioners have made a report that the boundaries have been demarcated in accordance with the arrangements, then as from such date not earlier than the date of the report as may be specified in the [OIC] the boundaries of the said areas shall be boundaries demarcated by the Commissioners. ${ }^{216}$

S 3 (Operation of existing laws). (1) On and after the appointed day any existing law which operates as law of, or of any part of, the [UK] being a law applying in relation to Cyprus or persons or things in any way belonging thereto or connected therewith, shall, save as provided after the passing of this Act by the authority having power to amend or repeal that law or by the following

their own constitutions.' For later developments in respect of South Africa, the Irish Free State and Newfoundland, see Ridges, n 17, pp 5319.

${ }^{213}$ See discussion in GS McBain, The Religion of the Sovereign. Time for Change (2011) Queensland LR, 1-48 at pp $22-4,27$.

${ }^{214} \mathrm{Ibid}$, pp 35-8. Legislation prohibiting the sovereign being a catholic is laid down in UK legislation. If this is repealed it would be for countries which have the sovereign as their Head of State to determine whether they wished to continue to do so.

${ }^{215}$ For the position in 1934, see Ridges, n 17, pp 578-83. Halsbury, Statutes ( ${ }^{\text {th }}$ ed), vol 10(1), p 71 '[the 1947 Act] has become spent as there are now no trust territories remaining for which the [UK] is responsible.'

${ }^{216}$ See Hendry, n 56, pp 19, 62, 366-8. 
provisions of this Act, continue to apply in like manner in relation to the [ROC] or persons or things in any way belonging thereto or connected therewith: ${ }^{217} \cdot 218$

S 4. (Citizenship). (1) For the purpose of giving effect to any agreement for the establishment of the [ROC], [HM] may by [OIC] provide that persons of such descriptions as may be specified in the Order shall cease to be citizens of the [UK] and colonies on such date as may be so specified, and different dates may be specified in relation to different descriptions of persons: Provided that a married woman shall not cease by virtue of an Order under this [s] to be a citizen of the [UK] and colonies if on the date on which she would do so her husband is a citizen of the [UK] and colonies and does not cease to be such a citizen on that date. (5) An [OIC] under this [s] may be varied or revoked by a subsequent Order. (6) An [OIC] under this [s] shall be subject to annulment in pursuance of a resolution of either House of Parliament.

$\mathrm{S} 6$ (Provision in event of change in relationship of Republic to the Commonwealth). For the purpose of giving effect to any decision that the [ROC] shall not be a country mentioned in Schedule 3 to the British Nationality Act 1981, [HM] may by [OIC] remove the $[\mathrm{ROC}]$ from that Schedule. (2) An [OIC] under this [s] may provide either that all the provisions of [s 3] of this Act and of the Schedule thereto (except in so far as they relate to the areas mentioned in [s 2(1)] of this Act) shall cease to have effect or that those provisions shall continue in force to such extent and subject to such modifications as may be specified in the Order, may make such adaptions or modifications of any Act (other than this Act) in force at the making of the Order or passed before then and coming into force thereafter, or any instrument having effect under any such Act, as appear to [HM] in Council expedient for the purposes or in consequence of the Order, and may contain incidental, consequential and supplemental provisions. (3) An [OIC] under this [s] may be varied or revoked by a subsequent such Order, and any amending Order may be made so as to have effect from any date not earlier than the making of the Order amended. (4) No recommendation shall be made to [HM] in Council to make an [OIC] under this [s] unless a draft of the Order has been laid before Parliament and approved by a resolution of each House of Parliament.

S 7. (1) (Short Title and Interpretation) This Act may be cited as the Cyprus Act 1960. (2) In this Act "the appointed day" means the day specified by [OIC] under [s 1] of this Act, "the Island of Cyprus" includes any island included in Cyprus before the appointed day, and references to the Island of Cyprus or any part thereof include references to the territorial waters of the Island or part.

Cyprus became a republic as long ago as 1960 . Thus, the sections (other than those relating to the SBA) appear spent and should be repealed.

\section{The provisions of this Act, to the extent still required should be set out in an Appendix to a BTFRA. 24. COLONIAL LEGISLATION - WEST INDIES ACTS 1962 \& 1967}

(a) Sections of the 1962 Act

This Act has the following sections:

3. (Compensation scheme for officers of Federal public service). (1) [HM] may by Order in Council [OIC] make such provision as appears to Her necessary of expedient - (a) for securing that the payment of a pension, gratuity, allowance or other like benefit to a person in respect of service of his, or that of another's, in the public service of the Federation is not prejudiced by reason of a colony's ceasing to be included in the Federation or of the dissolution of the Federation; (b) for securing the making of payments to or in respect of persons who, at the passing of this Act, are serving in that public service and, by reason of the happening of either of the events aforesaid, lose office or, by reason of being transferred to some other service, become in a worse position in respect of the conditions of their service as compared with the conditions of service formerly obtaining with respect to them; (c) for securing the payment to or in respect of such persons as are mentioned in the last foregoing paragraph who are transferred as

\footnotetext{
${ }^{217}$ It continues 'Provided that, save as aforesaid and subject to the provisions of the Schedule to this Act, any such law which contains different provision with respect to a Commonwealth country mentioned in Schedule 3 to the British Nationality Act 1981 and with respect to parts of [HM's] dominions outside the [UK] not so mentioned, or expressly excludes any such Commonwealth country to any extent, shall apply in like manner and to the like extent (if any) with respect to the [ROC] as it applies with respect to the said Commonwealth country. (2) As from the appointed day, the provisions of the Schedule to this Act shall have effect with respect to the enactments therein mentioned. (3) [HM] may by [OIC] make such further adaptions (whether in relation to the [ROC] or in relation to the areas mentioned in [s 2(1)] of this Act) in any Act of the Parliament of the [UK] passed before the appointed day, or in any instrument having effect under any such Act, as appear to Her necessary or expedient in consequence of the establishment of the [ROC]. (4) An [OIC] under this [s] may be varied or revoked by a subsequent such Order and may, though made after the appointed day, be made so as to have effect from that day. (5) An [OIC] under this [s] shall be subject to annulment in pursuance of a resolution of either House of Parliament...[For s 6 see below] ((7) Nothing in this [s] shall be construed as continuing in force any enactment or rule of law limiting or restricting the legislative powers of the [ROC]. (8) Nothing in this [s] shall be construed as requiring the application of any existing law to the [ROC] and the areas mentioned in [s 2(1)] of this Act as one country.'

${ }^{218}$ This is spent '(6) In this [s] "existing law" means any Act of Parliament (other than this Act) or other enactment or instrument whatsoever, and any rule of law, which is in force on the appointed day or, having been passed or made before the appointed day, comes into force after that day; and [ss] (1) of this section shall apply in relation to existing law which operates as law of, or any part of, Southern Rhodesia or any colony, protectorate or [UK] trust territory as it applies in relation to existing law which operates as law of, or of any part of, the [UK], except that that [ss] - (a) shall not apply in relation to any law passed by the Federal Legislature of Rhodesia and Nyasaland; (b) shall apply in relation to other law of, or of any part of, Southern Rhodesia so far only as concerns law which can be amended neither by a law passed by the Legislature thereof nor by a law passed by the said Federal Legislature; and (c) shall apply in relation to other law of, or of any part of, Northern Rhodesia or Nyasaland so far only as concerns law which cannot be amended by a law passed by the said Federal Legislature. References in this subsection to a colony, a protectorate and a [UK] rust territory shall be construed as if they were references contained in the British Nationality Act 1948.'
} 
therein mentioned (whether or not they become in a worse position as so mentioned) of sums in respect of disturbance suffered by them in consequence of being so transferred. (2) An [OIC] under this [s] may provide for the raising of the moneys necessary to make payments falling to be made under the Order by either or both of the following means, namely, - (a) the appropriation of assets of the government of the Federation; (b) the making of contributions by all or any of the governments of the colonies included in the Federation at the passing of this Act. ${ }^{219}$

4. (Power of [HM] to establish common courts for West Indian colonies). (1) [HM] may by [OIC] provide - (a) for the establishment, in place of the Federal Supreme Court of the Federation, of a court constituted in such manner as may be specified in the Order and having such jurisdiction to hear and determine appeals from, and to determine questions of law reserved by judges of, the courts of the relevant colonies as may be determined by or under the Order; (b) confer, or provide for conferring, on the court established by the Order, jurisdiction to hear and determine appeals from, and to determine questions of law reserved by judges of, the courts of such other colonies as may be specified in the Order; (c) confer upon the legislature of a colony from whose courts criminal appeals lie to the court established by the Order power to make, with extra-territorial operation, laws providing for the conveyance of prisoners to and from the place where that court is sitting. (2) [HM] may, by [OIC], provide for the establishment for the relevant colonies or for any two or more of them of courts additional to that whose establishment is authorised by the foregoing subsection, being courts constituted in such manner and having such jurisdiction (whether civil or criminal, original or appellate) as may be determined by or under the Order. (3) An [OIC] under this [s] may provide for the expenses of maintaining a court established by the Order to be defrayed by the governments of the colonies for which it is established. (4) In this [s] - (a) "relevant colonies" means, for the purposes of [ss] (1), the colonies from whose courts appeals lie at the passing of this Act to the Federal Supreme Court of the Federation and, for the purposes of [ss] (2), the colonies aforesaid with the exception of British Guiana; (b) "appeals" include appeals by way of cases stated.

5. (Power of [HM] to provide for government of certain West Indian colonies). (1) [HM] may by Order in Council [OIC] make such provision as appears to Her expedient for the government of any of the colonies to which this [s] applies, and for that purpose may provide for the establishment for the colony of such authorities as She thinks expedient and may empower such of them as may be specified in the Order to make laws either generally for the peace, order and good government of the colony or for such limited purposes as may be so specified subject, however, to the reservation to Herself of power to make laws for the colony for such (if any) purposes as may be so specified. (2) The power conferred by the foregoing [ss] shall include power to provide for the establishment of an authority to be charged, or authorities to be severally charged, with the duty of performing for the benefit of the said colonies, or for a combination of any two or more of them, such functions as may be specified in the Order, and for the expenses of an authority so charged to be defrayed by the governments of the colonies for whose benefit it is to perform functions. In this subsection "authority" does not include a legislature or court. (4) An [OIC] under this [s] with respect to a colony may vary or revoke any enactment or Letters Patent relating to the government of the colony and any Order in Council or other instrument so relating which has effect otherwise than by virtue of this $[\mathrm{s}]{ }^{220}$ (6) The colonies to which this $[\mathrm{s}]$ applies are those included at the passing of this Act in the Federation, and the Virgin Islands.

7. (Supplementary provisions as to Orders in Council). (1) An [OIC] under any provision of this Act may make or provide for the making of such incidental, consequential or transitional provisions as may appear to [HM] in Council to be necessary or expedient. (2) Any power conferred by this Act to make an [OIC] shall be construed as including power to vary or revoke the [OIC] by a subsequent [OIC]. (3) Subject to the following [ss], a statutory instrument containing an [OIC] under this Act which adapts or modifies any Act shall be subject to annulment in pursuance of a resolution of either House of Parliament, and a statutory instrument containing an [OIC] under this Act which does not adapt or modify any Act shall be laid before Parliament after being made. (4)The last foregoing [ss] shall not apply to an instrument containing an [OIC] under [s 6] of this Act making provision for the federation of, or the establishment of any other new form of government for, any colonies, but no recommendation shall be made to $[\mathrm{HM}]$ in Council to make an Order under the said [s 6] making such provision unless a draft of the Order has been laid before Parliament and approved by resolution of each House of Parliament.

8. (Grants for benefit of certain West Indian colonies). The [SS] may - (a) from time to time make, to the government of any colony to which [s 5] of this Act applies, being a government whose resources are, in his opinion, insufficient to enable it to defray its administrative expenses, grants of such amounts as he may, with the approval of the Treasury, determine; (b) from time to time make, to any federal government established by virtue of [s 6] of this Act for any colonies, grants of such amounts as he may, with the like approval, determine, for the purpose of enabling that government to make grants to the governments of any of the colonies for which it is established whose resources are, in its opinion, insufficient to enable them to defray their administrative expenses; (c) from time to time make, to a government of any other form established as aforesaid for any colonies, being one whose resources are, in his opinion, insufficient to enable it to defray its administrative expenses, grants of such amounts as he may, with the like approval, determine. ${ }^{221}$

\footnotetext{
${ }^{219}$ This section is, likely, spent.

${ }^{220}$ Ss 5 appears to be spent. It provides: '(5) Any [OIC] under the Jamaica Act 1866, the Saint Vincent and Grenada Constitution Act 1876, the Trinidad and Tobago Act 1887, the Dominica Act 1938, [s 3] of the Leeward Islands Act 1956 or [s 2] of the Cayman Islands and Turks and Caicos Islands Act 1958 (except the [OIC] mentioned in [ss (5)] of the last foregoing [s], so far as subsisting by virtue of any of those enactments) shall, in so far as it is in force at the passing of this Act and could be made under this [s], have effect as if so made, and so shall the Windward Islands and Leeward Islands (Police Service Commission) Order in Council 1959.'

${ }^{221}$ See also Hendry, n 56, p 245.
} 
9. (Expenses). The expenses incurred under the last foregoing [s] by the [SS] shall be defrayed out of moneys provided by Parliament, and any increase attributable to an [OIC] under this Act in sums payable under any other enactment out of moneys so provided or out of the Consolidated Fund of the [UK] shall be paid out of moneys so provided or out of that Fund, as the case may be.

This Act now only applies (if at all) to a limited number of BOT, as Hendry noted:

This Act is the statutory legal basis for the Constitution of the Cayman Islands, Monserrat, the Turks and Caicos Islands, and the Virgin Islands. 222

He also noted that the constituent powers for the above were set out in ss 5 and 7 . And, that the power conferred by s 5(1) had been held to be plenary. ${ }^{223}$ In the case of the West Indies Act 1976, s 6 (1) the power enabled the establishment of common courts:

Section 6(1) enabled [HM] by [OIC] to establish common courts for the associated states of Antigua, Dominica, Grenada, Saint Christopher, Nevis and Anguilla, Saint Lucia and St Vincent. Section 6(2) allowed Monserrat and the Virgin Islands to be brought within the jurisdiction of such common courts. ${ }^{224}$

\section{(b) $\underline{\text { Reform }}$}

The West Indies Federation no longer exists. ${ }^{225}$ Thus, a TRFA should contain any relevant material. In the case of ss 5 and 7, as indicated elsewhere, general provision should be made for the establishment of courts and government in all BOT. In conclusion, the West Indies Acts 1962 and 1967 should be repealed and any material still relevant should be placed in a BTFRA.

\section{COLONIAL LEGISLATION - ANGUILLA ACT 1980}

This Act, s 1 provides: ${ }^{226}$

(Future status and administration of Anguilla). (2) [HM] may by [OIC] make such provision as appears to Her expedient for and in connection with the government of Anguilla. (3) [HM] may by [OIC] make provision - (a) for and in connection with the attainment by Anguilla of fully responsible status; (b) for and in connection with the establishment of Anguilla as an independent republic; or (c) after such provision as is mentioned in paragraph (a) has been made, in connection with Anguilla becoming a republic; and an Order so made may make such modifications of any enactment of the Parliament of the [UK] or of any instrument having effect by virtue of such an enactment, and such transitional or other incidental and supplementary provisions, as appear to [HM] to be necessary or expedient.

In this [SS] "modifications" includes additions, omissions and alterations, and references to any enactment of the Parliament of the [UK] include references to any enactment comprised in Northern Ireland legislation. (4) An [OIC] under [ss 2] may be made at any time after the passing of this Act but, if made before the appointed day, shall not come into force before that day; and no recommendation shall be made to [HM] to make an Order under [ss] (3) unless a draft of the Order has been laid before and approved by a resolution of each House of Parliament. ${ }^{227}$

In respect of this, Hendry noted:

There is no express provision in this Act enabling an [OIC] made under [s 1(2)] to be varied or revoked. This was unnecessary because its enactment post-dated the Interpretation Act 1978, [s] 14 of which provides for an implied power to amend or revoke $[\mathrm{OIC}]$ made under an Act. ${ }^{228}$

Such is an additional good reason to modernise all BOT legislation, since the same need not then be repeated as it is in much of the colonial legislation discussed.

In conclusion, a BTFRA should consolidate this legislation.

\footnotetext{
${ }^{222}$ Ibid, p 17.

${ }^{223}$ Ibid, p 18 citing $R$ (Misick) v SS for Foreign and Commonwealth Affairs [2009] EWHC 1039 (Admin) upheld by the Court of Appeal: [2009] EWCA Civ 1549.

${ }^{224}$ Hendry, $\mathrm{n} 56, \mathrm{p}$ 106. See also s 6 (Establishment of common courts for associated states). (1) [HM] may by [OIC] made before the appointed day provide for the establishment of one or more courts which, on and after that day or such later day as may be specified in, or determined in accordance with, the Order, shall be courts constituted in common for the territories to which [s 1] 1 of this Act applies, and may by that Order provide that any such court shall, in relation to any of those territories, have such jurisdiction and powers as may be so specified or determined. (2) An [OIC] under this [s] may include provision whereby, in relation to Anguilla, Montserrat or the Virgin Islands, any court established under the Order shall have such jurisdiction and powers, and there shall be imposed or conferred on judges and officers of any such court such duties and powers, as may be specified in, or determined in accordance with, the Order.

${ }^{225}$ For the legal explanation, see Halsbury, Statutes, $\left(5^{\text {th }}\right.$ ed), vol 10(1), p 72.

${ }^{226}$ See also Hendry, n 56, pp 18-9.

${ }^{227}$ The following appears spent '(5) The Anguilla Act 1971 (which is superseded by this [s]) is hereby repealed as from the appointed day. (6) The repeal effected by [ss 5] shall not affect any Order in Council or appointment of a Commissioner made under the said Act of 1971; but any such Order or appointment may be revoked by or under an Order in Council made under [ss 2].'

${ }^{228}$ Hendry, n 56, p 18.
} 


\section{COLONIAL LEGISLATION - BERMUDA CONSTITUTION ACT 1982}

This Act, $\mathrm{s} 1$ (Power to provide by Order in Council for the government of Bermuda) provides: ${ }^{229}$

(1) $[\mathrm{HM}]$ may by Order in Council [OIC] make such provision as appears to Her expedient for the government of Bermuda.

(2) Any [OIC] under this [s] may vary or revoke, or provide for the variation or revocation of, any Letters Patent relating to the government of Bermuda, any instrument issued in pursuance of any such Letters Patent, or any law relating to the government of Bermuda and made by any legislature for the time being constituted as the legislature of Bermuda.

(3) Any [OIC] under this [s] may be varied or revoked by a subsequent [OIC] thereunder, but otherwise shall not be capable of being varied or revoked except by Act of Parliament.

(4) Any [OIC] under this [s] shall be laid before Parliament after being made.

(5) In this Act "Bermuda" means the islands known as Bermuda or as the Bermudas or Somers Islands.

If this section were re-enacted, then (3) would not be required. Further, given that the sovereign only has formal power - and to ensure greater accountability - anything formerly in letters patent should now be in a SI. Thus, (2) would no longer be needed. Nor the reference 'as appears to Her expedient' in (1). As to (4), today, it would be appropriate for all SI relating to BOT to be laid before Parliament.

In conclusion, a BTFRA should consolidate this legislation, providing that the UK Parliament might legislate for BOT by means of SI (as well as by general legislation which expressly refers to the same).

\section{COLONIAL LEGISLATION - CANADA ACT 1982}

(a) Repealing this Act

Canada was a dominion. ${ }^{230}$ By the Statute of Westminster 1931 it was empowered for Canada to exercise sovereign powers of amendment over its own constitution. ${ }^{231}$ The Canada Act 1982, s 1 enacted a Canadian constitution. ${ }^{232}$ Section 2 provided that no future Act of the UK Parliament was to extend to Canada as part of its law after the coming into force of the Canada Constitution Act 1982 (which occurred). As Marshall noted, this was a purported termination of the UK Parliament's power of legislation. ${ }^{233}$ Such was no different to post -1947 colonial independence legislation (see 8).

- It is suggested the Canada Act 1982 should now be repealed. It was intended to deal with a savings clause in the Statute of Westminster 1931 which prevented the Canadian Federal parliament from acquiring additional powers to amend the British North America Acts. ${ }^{234}$

- As to this, the truth of the matter is that (as Marshall noted in 1984) the Statute of Westminster 1931 was flawed and that such a flaw extended to the savings clauses. In hindsight it would have been better without such since, in the end, they were removed by Canada (and Australia) not without controversy. ${ }^{235}$

Thus, Marshall stated:

the British gift of sovereignty conveyed in s 2 of the 1931 statute had built into it an inherent and continuing constitutional uncertainty, since the legal instrument by which it was conveyed failed to provide clearly for the manner and form of its exercise. Despite the attempt to deal in the Statute of Westminster [1931] with the federal difficulties of Canada and Australia by specific savings clauses, an uncertainty in the operation of constitutional convention led there also to major political controversy and crisis. The uncertainty in these cases was as to the conditions under which the powers of the [UK] Parliament would continue to be used for dominion purposes. ${ }^{236}$

If the Canada Act 1982 were repealed ${ }^{237}$ this would end the saga of the badly drawn Statute of Westminster 1931 and put Canada (and Australia) on the same legal basis as post-1947 colonies that have become independent viz.

\footnotetext{
${ }^{229}$ Ibid.

${ }^{230}$ For a summary of the early history, see Amos, n 73, p 150 et seq.

${ }^{231}$ For background to this in respect of Canada see WPM Kennedy, Essays in Constitutional Law (1934). See also Ridges (in 1934), n 17, pp $522-6$.

${ }^{232}$ Thus, s 1 (Constitution 1982 enacted) states 'The Constitution Act set out in Schedule B to this Act is hereby enacted for and shall have the force of law in Canada and shall come into force as provided in the Act'. Section 3 provided for a French version.

${ }^{233}$ Marshall, n 122, p 173, n 3.

${ }^{234}$ It may be noted that South Africa and the Irish Free State did not have such savings clauses and they later changed their constitutions including so-called 'entrenched' clauses. Marshall, n 122, pp 177-8.

${ }^{235}$ See Marshall, n 122, ch 11.

${ }^{236}$ Ibid, p 179

${ }^{237}$ Repeal of this Act would not effect the factual efficacy of the same vis-à-vis the application of UK legislation (nor the repeal of various independence Acts, s 1. It would simply place them on the same basis as countries which are independent (e.g. France, Germany). UK legislation does not apply because their legal systems do not so apply it. And, if a UK Parliament purported to exercise an exorbitant jurisdiction they would ignore the same (regardless of any purported efficacy under UK law). Patriation and autonomy are legally and factually complete on the non-application of the law of the UK Parliament and there is no place for asserting subsequent convention or hypothetical speculation. Cf. Marshall, n 122, p 209.
} 
that UK legislation no longer applied. ${ }^{238}$ Such would seem appropriate. In other words, it is not for the UK legislation to interfere these days in any governmental matters of Canada. That is now for the politicians (and the general public in Canada) to determine and sort out in a modern democracy. The Statute of Westminster 1931 also shows the inefficacy of 'residual powers' type clauses. They are only conducive to controversy and (almost endless) legal problems. Thus, such residual powers were not contained in post-1947 colonial independence legislation and such (in practice) did not give rise to problems. As to Crown prerogatives affecting Canada, the position of the governor general ('G-G') of Canada may also be noted.

(b) Governor General of Canada ('G-G')

At present, Canada has a G-G appointed by the Crown - presumably, with the sovereign acting as the Head of State of Canada. ${ }^{239}$ Since 1930, the rule has been that the same is appointed on the advice of the government of the country concerned. ${ }^{240}$

- The problem of the sovereign becoming involved in the appointment of a G-G is that the sovereign, thereby, becomes involved in the dismissal of the same, and all the acrimony that such may engender. ${ }^{241}$ Today, it would seem better (wiser) if this office is abolished. Or, that any G-G is appointed by Canada.

- The case of the G-G in respect of the Gough Whitlam government in Australia in 1975 indicated that the sovereign treated the Crown prerogative to appoint (and dismiss) not as a personal one. ${ }^{242}$ It may also be that the position in Australia is different to that in Canada. In short, it is not at all clear the precise relationship between the sovereign and her G-G in Canada (or in Australia). More importantly, since G-G are involved in political decision making, it might be better to dispense with them. Such would not affect the sovereign being the Head of State of Canada (or Australia). ${ }^{243}$

In conclusion, it is suggested the Canada Act 1982 should also be repealed. This Act was intended to deal with a savings clause in the Statute of Westminster 1931 which prevented the Canadian federal parliament from acquiring additional powers to amend the British North America Acts (as well as to prevent Australia amending the Commonwealth of Australia Constitution Act). ${ }^{244}$

\section{In conclusion, the Canada Act 1982 should be repealed.}

\section{COLONIAL LEGISLATION - AUSTRALIA ACT 1986}

(a) Content of Act

Presently, this $\mathrm{Act}^{245}$ contains the following extant sections:

$\begin{array}{ll}\text { S } 1 & \text { (Termination of Power of Parliament of [UK] to legislate for Australia) } \\ \text { S } 2 & \text { (Legislative Powers of Parliaments of States) } \\ \text { S } 3 & \text { (Termination of Restrictions on Legislative Powers of Parliaments of States) } \\ \text { S } 5 & \text { (Commonwealth Constitution, Constitution Act and Statute of Westminster not affected) } \\ \text { S } 6 & \text { (Manner and Form of making certain State laws) } \\ \text { S } 7 & \text { (Powers and Functions of [HM] and Governors in respect of States) } \\ \text { S } 8 & \text { (State Laws not subject to Disallowance or Suspension of Operation) } \\ \text { S } 9 & \text { (State Laws not subject to withholding of assent or reservation) } \\ \text { S } 10 & \text { (Termination of responsibility of [UK] Government in relation to State Matters) } \\ \text { S } 15 & \text { (Method of Repeal or Amendment of this Act or Statute of Westminster) } \\ \text { S } 16 & \text { (Interpretation) }\end{array}$

Other sections terminated appeal to the JCPC (s 11) and made various amendments (ss 12-4).

\footnotetext{
${ }^{238}$ See also Marshall, n 122, p 208.

${ }^{239}$ Cf. Marshall, n 122, pp 173-5.

240 Ibid.

${ }^{241}$ See removal of the G-G of the Irish Free State in 1932 at the request of De Valera. See also the G-G of Australia (Sir John Kerr) in 1975 dismissing Gough Whitlam and his government to resolve a Parliamentary deadlock. Marshall, n 122, pp 173-4. It seems that the G-G did not tell the sovereign what he was going to do in advance, Bogdanor, $\mathrm{n} 157, \mathrm{p} 277$ who also noted that there had been a number of instances when governor and G-G had been dismissed, Ibid, p 282.

${ }^{242}$ Marshall, n 122, pp 174-5.

${ }^{243}$ The problem for the sovereign is that the role of the same in the appointment (and dismissal of G-G) has long been formal. For example, Bogdanor, n 157, p 247 'Sir Isaac Isaacs an Australian, was appointed [G-G] of Australia [in 1930] on the advice of the Australian government against the wishes of George V [1936-52].'

${ }^{244}$ It may be noted that South Africa and the Irish Free State did not have such savings clauses and they later changed their constitutions including so called entrenched clauses. Marshall, $\mathrm{n} 122$, pp 177-8.

${ }^{245}$ For a summary of the early history, see Amos, n 73, p 150 et seq. Also, Ridges (in 1934), n 17, pp 526-31.
} 


\section{(b) Repeal of Act}

The rationale for the repeal of this Act, is the same as that for the Canada Act 1982 (see 27). Repeal of this Act and the Statute of Westminster 1931 requires (pursuant to s 15 of the Australia Act 1986) that it be effected by the Australian Federal Parliament 'at the request of or with the concurrence' of the Australian States, albeit such does not limit (or prevent) the exercise by the Federal Parliament of any powers conferred on it by any alteration to the Australian Constitution (by s 128 of the same).

In conclusion, the Australia Act 1986 should be repealed according to its terms. Further, there should be consideration whether it still needs a $G-G$, as applies also in respect of Canada.

\section{SPENT \& OTHER LEGISLATION}

Besides this legislation, there is, also, material extant relating to foreign affairs viz.

- Foreign Compensation Acts 1950, 1962, 1969 \& $1992^{246}$

- Japanese Treaty of Peace Act 1951 (s 1)

- Austrian State Treaty Act 1955 (s 1)

- German Conventions Act 1955 (s 1)

These should be repealed as spent (the compensation fund was wound up in 2013). ${ }^{247}$ There is, also, the following (mainly piecemeal) legislation relating to:

- Hong Kong

- Cyprus

- Antartic

- Commonwealth

- UN

- International Organisations

- International Protected Persons

These should be placed in Appendices to the FTRA

\section{CONCLUSION}

In 1999, Munro remarked 'To sum up, the exercise of prerogative powers is imperfectly subject to parliamentary control' ${ }^{248}$ Also:

there would be several advantages in replacing the existing prerogatives with statutory powers, such as the government more usually acts under. If that were done, the purposes and content of the powers could be clearly set out, whereas much of the law concerning the prerogative is obscure and derived from ancient precedents. Supervision of the exercise of the powers could be more efficiently carried out by Parliament and the courts. The opportunity for members of Parliament to consider and debate the appropriate limits of such powers would also provide an occasion for other arrangements to be mooted. ${ }^{249}$

One would (heartily) agree. The key problem - as noted before - is the divorce between the legal fiction that the sovereign (or the Crown in the body politic) is in charge of the operation of diplomacy and the reality that the sovereign (as well as the Crown in the body politic) exercises only a non-executive role. This can be seen (vividly) in the case of the Channel Islands, the Isle of Man and BOT. In reality, now, the role of both the sovereign and the privy council is that of rubber stamping decisions taken by the HO and the FCDO. However, the continued presence of the sovereign (and the Crown in the body politic) as well as the privy council detracts from transparency and accountability.

The result is (as Munro noted) imperfect parliamentary control. Such is neither appropriate, nor necessary, in a modern democratic society. The solution is not difficult. A BTFRA should place in statute form the legal relationship between the UK and the Channel Islands, the Isle of Man and BOT, excising reference to the Crown and to the privy council. Then, everyone knows where they stand. As for other legislation, that relating to colonies now independent (as well as Canada and Australia) should be repealed as spent. Or, if really required, consolidated in an Appendix to a BTFRA for easy access and enabling the excision of dead sections. So too, material on Cyprus and Hong Kong. Also, material on the Commonwealth, the UN, International Organisations and International Protected Persons. This will enable easy access and comparison instead of lawyers (and others) having to plough through a mass of Acts. None of this is difficult.

\footnotetext{
${ }^{246}$ De Smith, n 23, p 149 (writing in 1998) 'Under the Foreign Compensation Acts 1950 and 1969, the allocation of sums received from foreign governments under treaty as compensation for the confiscation or destruction of British-owned property, the Foreign Compensation Commission.'

${ }^{247}$ Foreign Compensation Commission (Winding-Up) SI 2013/236.

${ }^{248}$ Munro, n 24, p 278.

${ }^{249}$ Ibid, p 291.
} 
Besides the above, all Crown prerogatives relating to foreign relations should be abolished. This matter is dealt with in Part 2 of this article.

\section{Appendix 1 - BRITISH TERRITORIES AND FOREIGN RELATIONS ACT}

An Act to consolidate various constitutional matters relating to British territories and to foreign affairs.

\section{Contents}

\section{Part 1: British Domestic Territories (BDT)}
1. Channel Islands and Isle of Man
2. Application of UK legislation
3. Defence and Foreign affairs
4. Responsible UK Ministry
5. Content of Statutory Instrument
6. Abolition of Crown Prerogatives
7. Appeal to Supreme Court
8. Abolition of Feudal Services
9. Rockall
10. Repeal of Legislation

\section{Part 2: British Overseas Territories (BOT)}

11. Territories comprising BOT

12. Application of UK legislation

13. Defence and Foreign affairs

14. Responsible UK Ministry

15. Content of Statutory Instrument

16. Abolition of Crown Prerogatives

17. Appeal to Supreme Court

18. St Helena

19. Admiralty Jurisdiction

20. Repeal of Legislation

\section{Part 3: Consolidation of Legislation}

21. Former Colonies or Dominions

22. Australia

23. Hong Kong

24. Cyprus

25. Antartic

26. Commonwealth

27. United Nations

28. International Organisations

29. International Protected Persons

\section{Part 4: General}

30. Abolishing Obsolete Terminology

31. Interpretation, Repeals and Application

\section{Part 1: British Domestic Territories}

\section{Channel Islands and Isle of Man}

(1) The Channel Islands and the Isle of $\mathrm{Man}^{250}$ are domestic territories of the UK ('BDT').

\section{Application of UK Legislation}

(1) The UK may legislate for a BDT by means of a:

(a) UK Act of Parliament which expressly refers to the same; ${ }^{251}$ or a

(b) SI.

\footnotetext{
${ }^{250}$ There is no need to draw any distinction between the same as UK territories. Thus, reference is made to both.

${ }^{251}$ Implied application leaves the matter too uncertain. See also Blackstone (writing in 1765), n 31 ('particularly named').
} 
(2) Legislation passed by a BDT legislature shall only be void and inoperative if (and to the extent) it is:
(a) repugnant to ${ }^{252}$
(b) the legislation in (1). ${ }^{253}$

\section{Defence and Foreign Affairs}

(1) The UK is responsible for the defence and foreign affairs of BDT..$^{254}$

\section{Responsible UK Ministry}

(1) The $\mathrm{HO}$ is the UK ministry primarily responsible for the relationship between the UK and BDT, including:

(a) the drafting of legislation in $\mathrm{s} 2(1)$;

(b) the appointment, and dismissal, of any Governor.

(2) The HO may seek the assistance of other UK ministries in respect of s 4(1).

\section{Content of Statutory Instrument}

(1) A SI may, inter alia, provide, in respect of BDT, for the following:
(a) their constitution (and any variation, amendment or replacement thereof);
(b) any legislature;
(c) their government;
(d) the establishment of any court;
(e) the appointment, and dismissal, of a Governor and the powers of the same;
(f) any customs or common duty or tax;
(g) any Crown land or Crown revenues.

(2) The power in (1) includes making any incidental, consequential or transitional provisions relating thereto.

\section{Abolition of Crown Prerogatives}

(1) Any Crown prerogative applying to BDT is abolished and:

(a) all matters relating to BDT undertaken by the Privy Councili, 255

(b) are hereby transferred to the HO.

\section{Appeal to Supreme Court}

\section{Abolition of Feudal Services}

(1) All feudal services and obligations to the Crown (or for any franchisee) in the BDT are abolished, including any:

(a) obligation to pay homage or fealty for the holding of land;

(b) escheat or forfeiture for breach of a feudal service relating to land;

(c) oath (or affirmation) required for the holding of land.

\section{Rockall}

(1) The island of Rockall is a BDT.

(2) Rockall is part of the UK pursuant to the Island of Rockall Act 1972 and, from the date of the enactment of the same, the island (of which possession was formally taken in the name of [HM] on 18th September 1955 in pursuance of a Royal Warrant dated 14th September 1955 addressed to the Captain of [HM's] Ship Vidal) was incorporated into that part of the UK known as Scotland and formed part of the Western Isles, and the law of Scotland applied accordingly.

\section{0. $\underline{\text { Repeal of Legislation }}$}

(1) The legislation in Appendix 1, Part $A$ is repealed. ${ }^{257}$

\footnotetext{
${ }^{252}$ More modern wording would be 'incompatible with'.

253 This reflects the Colonial Laws Validity Act 1865, s 2. However, as noted in 13, the same may not be required.

${ }^{254}$ This states what has always been the case since 1204 (in the case of the Channel Islands) and 1765 (if not before, in the case of the Isle of Man).

${ }^{255}$ Cf. De Smith (writing in 1998), n 23, p 57 as to the Privy Council committees never meeting as deliberative bodies and the HO being the 'dominant figure' in them.

${ }^{256}$ This would not be needed if a Courts Act (see n 1) otherwise provides for the abolition of the JCPC and the transfer of its jurisdiction to the UK Supreme Court.

${ }^{257}$ See 3(d) and 4. This colonial legislation should be repealed and any sections still required be updated in a SI.
} 


\section{Part 1: British Overseas Territories (BOT)}

\section{Territories comprising BOT}

(1) The territories set out in Appendix 10 (as the same may be amended by a SI from time to time) comprise BOT, together with the legal form, and date, of acquisition.

(2) All BOT referred to in Appendix 10, Part A (settled territories) have, from the date of their acquisition, as their law: 258

(a) the law of England at the time of acquisition

(b) as altered (or replaced) by subsequent local legislation; or

(c) UK legislation.

(3) All BOT referred to in Appendix 10, Part B (ceded and annexed territories) have, from the date of their acquisition, as their law: ${ }^{259}$

(a) the law in force in the territory at the time of acquisition

(b) as altered (or replaced) by subsequent local legislation; or

(c) UK legislation.

\section{Application of UK Legislation}

(1) The UK may legislate for the BOT by means of a:

(a) UK Act of Parliament which expressly refers to the same; ${ }^{260}$ or a

(b) SI.

(2) Legislation passed by a BOT legislature shall only be void and inoperative if (and to the extent) it is:

(a) repugnant to

(b) the legislation in (1).

\section{Defence and Foreign Affairs}

(1) The UK is responsible for the defence and foreign affairs of BOT.

\section{Responsible UK Ministry}

(1) The FCDO (or the MOD in the case of the SBA) is the UK ministry primarily responsible for the relationship between the UK and BOT, including:

(a) the drafting of legislation in $\mathrm{s} 13$;

(b) the appointment, and dismissal, of any Governor.

(2) The FCDO (or MOD) may seek the assistance of other UK ministries in respect of s 14(1).

\section{Content of Statutory Instrument}

(1) A SI may, inter alia, provide, in respect of the BOT, for the following:

(a) their constitution (and any variation, amendment or replacement thereof);

(b) any legislature;

(c) their government;

(d) the establishment of any court;

(e) the appointment, and dismissal, of a Governor, and the powers of the same;

(f) any customs or common duty or tax;

(g) any Crown land or Crown revenues;

(f) the alteration of any territorial boundaries. ${ }^{261}$

(2) The power in (1) includes making any incidental, consequential or transitional provisions relating thereto.

\section{Abolition of Crown Prerogatives}

(1) Any Crown prerogative applying to BOT is abolished and:

(a) all matters relating to BOT undertaken by the Privy Councili, ${ }^{262}$

\footnotetext{
${ }^{258}$ E May, The Constitutional History of England (1882), vol 3, p 338 'Wherever they have founded colonies they have borne with them the laws and institutions of England, as their birthright, so far as they were applicable to an infant settlement.'

${ }^{259} \mathrm{Ibid}, \mathrm{p} 338$ 'In territories acquired by conquest or cessation, the existing laws of the people were respected, until they were qualified to share the franchises of Englishmen.'

${ }^{260}$ Implied application leaves the matter too uncertain. See also Blackstone (writing in 1765), n 38 ('particularly named').

${ }^{261}$ See Colonial Boundaries Act 1895, see 20.

${ }^{262}$ Cf. De Smith, see n 23.
} 
(b) are hereby transferred to the HO.

\section{Appeal to Supreme Court}

(1) Any appeal to the JCPC from a BOT shall now be to the UK Supreme Court. ${ }^{263}$

\section{Saint Helena}

(1) The island of Saint Helena is a BOT.

(2) Saint Helena (and its dependencies) is a BOT pursuant to the St Helena Act 1833, s 122 and, from the date of the enactment of the same, the island (and all stores and property thereon fit or used for the service of the government thereof) became vested in the Crown.

(3) The legislation in Appendix 1, Part B is repealed.

\section{Admiralty Jurisdiction}

(1) All BOT civil courts hereby have admiralty jurisdiction if the law of the BOT does not otherwise provide. ${ }^{264}$

\section{Repeal of Legislation}

(1) The legislation in Appendix 1, Part B is repealed. ${ }^{265}$

[Note. Sections could be inserted to deal with: admiralty crimes (see 12), colonial marriages (see 14), colonial prisoners (see 15). However, for the reasons given it is thought that such matters should be left to BOT legislatures (or to UK law) or to mutual assistance agreements (in the case of prisoners).

\section{Part 3: Other Legislation}

\section{Former Colonies and Dominions}

(1) The legislation in Appendix 1, Part C is repealed save for:

(a) extant sections which are consolidated in Appendix 2;

(b) together with the title of the former Act; and

(c) the date of its enactment.

\section{Australia}

(1) The legislation in Appendix 1, Part D shall be repealed (including the application of the Statute of Westminster 1931 as the same applies as between the UK and Australia) when an Act of the Commonwealth is passed according to the Australia Act 1986, s 12.

\section{Hong Kong}

(1) Appendix 3 shall apply to Hong Kong [i.e. consolidation of legislation referred to in Appendix 1, Pt E]

\section{Cyprus}

(1) Appendix 4 shall apply to Cyprus [i.e. consolidation of legislation referred to in Appendix 1, Pt F]

\section{Antartic}

(1) Appendix 5 shall apply to the Antartic [i.e. consolidation of legislation referred to in Appendix 1, Pt G]

\section{Commonwealth}

(1) Appendix 6 shall apply to the Commonwealth [i.e. consolidation of legislation referred to in Appendix 1, Pt $\mathrm{H}]$

\section{United Nations}

(1) Appendix 7 shall apply to the UN [i.e. consolidation of legislation referred to in Appendix 1, Pt I]

\section{International Organisations}

(1) Appendix 8 shall apply to International Organisations [i.e. consolidation of legislation referred to in Appendix 1 , Pt J]

\section{International Protected Persons}

(1) Appendix 9 shall apply to International Protected Persons [i.e. consolidation of legislation referred to in Appendix 1, Pt K]

\section{Part 4: General}

\section{Abolishing Obsolete Terminology}

(1) The following terms are abolished as obsolete:

\footnotetext{
${ }^{263}$ This would not be needed if a Courts Act (see n 1) otherwise provides for the abolition of the JCPC and the transfer of its jurisdiction to the UK Supreme Court.

${ }^{264}$ See 19 and the Colonial Courts of Admiralty Act 1890.

${ }^{265}$ See 3(d) and 4. These should be repealed and any sections still required be updated in a SI.
} 

(a) dependent territory (including Crown dependency);
(b) colony (including Crown colony);
(c) dominion;
(d) possession;
(e) protectorate;
(f) associated state.

\section{Interpretation, Repeals and Application}

(1) In this Act:

'BOT' means British Overseas Territory;

'FCDO' means the Foreign Commonwealth and Development Office;

'Governor' includes any commissioner or administrator (also, any deputy or person acting for any of the same)

'JCPC' means the Judicial Committee of the Privy Council;

'HO' means the Home Office;

'MOD' means the Ministry of Defence;

'SBA' refers to the Sovereign Base Areas in Cyprus;

'SI' refers to a statutory instrument;

'UK'means the United Kingdom;

'UN' means the United Nations.

(2) In this Act reference to the:

(a) 'sovereign' refers to the sovereign in person (that is, in the body natural);

(b) 'Crown' refers to the sovereign as well as the same in the body politic, unless otherwise provided.

(3) The legislation referred to in Appendix 1, Part $M$ is repealed.

(4) This Act extends to the:
(a) UK;
(b) Channel Islands;
(d) Isle of Man;
(e) BOT.

\section{Appendix 1: Foreign Relations Legislation}

[Extant sections are inserted by way of a note only and would not be placed in any legislation. Short titles should be excluded]

\section{A. Channel Islands \& the Isle of Man}

Alderney (Transfer of Property) Act 1923

Jersey and Guernsey (Financial Provisions) Act 1947

Isle of Man Act 1979

Island of Rockall Act 1972

\section{B. Former Colonies (now BOT)}

Saint Helena Act 1833

Admiralty Offences (Colonial) Act 1849

Admiralty Offences (Colonial) Act 1860

Colonial Affidavits Act 1859

Colonial Laws Validity Act 1865

Colonial Marriages Act 1865

Colonial Prisoners Removal Act 1869

Colonial Prisoners Removal Act 1884

Courts (Colonial) Jurisdiction Act 1874

British Settlement Act 1887 (and 1945)

Foreign Jurisdiction Act 1890

Foreign Jurisdiction Act 1913

Colonial Courts of Admiralty 1890

Colonial Boundaries Act 1895

\section{$\underline{\text { Sections }}$}

s 1
s 1
ss $1-12$
s 1
Sections
s 112
ss $1,3-5$
ss 1 \& 4
s 2
ss $1-6$
ss $1-2$
ss 1 \& $2,4-7$
ss $2-14$
ss 2-3
ss 2-6 (and 1$)$
ss $1-13,16 \& 19$
s 1
ss $2-15$
s 1


Statute of Westminster 1931

Mandated Trust Territories Act 1947

West Indies Act 1962

Anguilla Act 1980

Bermuda Constitution Act 1982

\section{Former Colonies (now Independent)}

Indian Independence Act 1947

Ceylon Independence Act 1947

Ireland Act 1949

India (Consequential Provision) Act 1949

Ghana Independence Act 1957

Federation of Malay Independence Act 1957

Ghana (Consequential Provision) Act 1960

Nigeria Independence Act 1960

Sierra Leone Independence Act 1961

Tanganyika Independence Act 1961

West Indies Act 1962

South Africa Act 1962

Jamaica Independence Act 1962

Trinidad and Tobago Independence Act 1962

Uganda Independence Act 1962

Tanganyika Republic Act 1962

Rhodesia and Nyasaland Act 1963

Malaysia Act 1963

Kenya Independence Act 1963

Zanzibar Act 1963

Nigeria Republic Act 1963

Uganda Act 1964

Malawi Independence Act 1964

Zambia Independence Act 1964

Malta Independence Act 1964

Gambia Independence Act 1964

Kenya Republic Act 1964

Guyana Independence Act 1966

Malawi Republic Act 1966

Botswana Independence Act 1966

Lesotho Independence Act 1966

Singapore Act 1966

Barbados Independence Act 1966

West Indies Act 1967

Bermuda Constitution Act 1967

Mauritius Independence Act 1968

Swaziland Independence Act 1968

Tanzania Act 1969

Guyana Republic Act 1970

Tonga Act 1970

Republic of The Gambia Act 1970

Fiji Independence Act 1970
Ss $1-10^{266}$

S 1

ss $3-5,7-8$

s 1

s 1

\section{Sections}

ss $1,6-7,15,20$.

ss $1,4-5$

ss $1,2,4,7$

ss $1-2$

Ss $1,4-5$

ss $1,2,4$

ss 1,3

ss $1,3-4$

ss $1-3-4$

ss $1,3-4$

ss $3-10$

ss $2-4$

Ss $1,3-4$

ss $1,3-5$

ss $1,3,5$

ss 1,3

ss $1-3$

ss 1,3-4,6

ss $1,4,8$

ss 1,6

ss $1-3$

ss $1,2,4$

ss $1,4,7-8$

ss $1,8,11$

ss $1,4-6$

ss $1,4,6-7$

ss $1-2$

ss 4-5,8-9

ss $1-2$

ss $1,2,8$

ss $1,2,8$

ss $1,3-5$

ss 1,4-6

ss $6,8,17,19$

ss 1,2

ss 1,4-5

ss $1-2,7-8$

ss $4-8$

ss $1-2$

ss $1,3-4$

ss 1-3

ss 1,4-6

${ }^{266}$ In the case of Australia, consent is required, see s 22. 
Sierra Leone Republic Act 1972

ss $1-2$

Sri Lanka Republic Act 1972

ss $1-2$

Bahamas Independence Act 1973

ss $1-7$

Bangladesh Act 1973

ss $1,3-4$

Malta Republic Act 1975

ss $1-2$

Seychelles Act 1976

Trinidad and Tobago Republic Act 1976

ss $1,2,5,7-8$

Tuvalu Act 1978

ss $1-4$

Solomon Islands Act 1978

ss $1,4-6$

ss $1-7,9$

Southern Rhodesia Act 1979

ss $1-4$

Zimbabwe Act 1979

ss $1,3-7$

Kiribati Act 1979

ss $1-3,6-8$

Anguilla Act 1980

ss $1-2$

New Hebrides Act 1980

ss 2,4

Papua New Guinea, Western Samoa and Nauru (Miscellaneous Provisions) Act 1980

ss $1,3-4$

Belize Act 1981

ss $1-7$

Canada Act 1982

ss $1-4$

Brunei and Maldives Act 1985

ss $1-2$

Brunei (Appeals) Act 1989

ss $1-2$

Pakistan Act 1990

ss $1-2$

Namibia Act 1991

ss $1-2$

Mauritius Republic Act 1992

ss $1-3$

South Africa Act 1995

ss $1-2$

\section{Australia}

\section{$\underline{\text { Sections }}$}

Australia Act 1986

ss $1-17$

E. Hong Kong ${ }^{267}$

$\underline{\text { Sections }}$

Hong Kong Act 1985

ss $1-2$

Hong Kong Economic and Trade Office Act 1996

ss $1-2$

\section{F. Cyprus}

Cyprus Act 1960

$\underline{\text { Sections }}$

\section{G. $\underline{\text { Antartic }}$}

ss $1-4,6-7$

Antartic Act 1994

\section{Sections}

ss $1-32,34-6$

\section{H. Commonwealth}

\section{Sections}

Commmonwealth Secretariat Act 1966

ss $1-2$

ss $1-4$

\section{United Nations}

United Nations Act 1946

$\underline{\text { Sections }}$

ss 1

ss $1-9$

\section{UN Personnel Act 1997}

\section{$\underline{\text { Sections }}$}

Int. Headquarters and Defence Organisations Act 1964

Ss $1-3$

International Organisations Act 1968

ss $1,2,4,4 \mathrm{~A}, 4 \mathrm{~B}, 5,5 \mathrm{~A}, 6-13$

International Organisations Act 1981

ss 4,6

International Parliament Organisations Registrations Act 1989

S 1

International Organisations Act 2005

ss $1,2,4,7-8,9-11$

Commonwealth Development Corporation Act 1978

s 1

Commonwealth Development Corporation Act 1999

Ss $1-28$

\section{K. International Protected Persons}

\section{$\underline{\text { Sections }}$}

${ }^{267}$ Acts relation to British nationality may be better dealt with in a revision of the British Nationality Act 1981 , see British Nationality (HK) Acts 1990 \& 1997, HK (War Wives and Widows) Act 1996 and HK (Overseas Public Servants) Act 1996. 
International Protected Persons Act 1978 Act

\section{Others}

Foreign Compensation Act 1950

Foreign Compensation Act 1962

Foreign Compensation Act 1969

China Indemnity (Application) Act 1931268

Japanese Treaty of Peace Act 1951

Austrian State Treaty Act 1955

German Conventions Act 1955

Treaties of Peace (Italy, Roumania, Bulgaria, Hungary and Finland) ${ }^{269}$

Appendix 2: BOT
$1-2,4-5$

\section{Sections}

ss $1,3-9$

ss $3-4$

ss $3-5$

ss $1-2$

ss $1-2$

ss $1-3$

ss $1-2$

\section{Part A: Settled Territories}

Anguilla

Bermuda

Cayman Islands

Falkland Islands

Monserrat

Pitcairn Islands

South Georgia \& South Sandwich Islands 270

St Helena, Ascension \& Tristan da Cunha

Turks and Caicos Islands

British Virgin Islands (BVI)

\section{Part B: Ceded Territories or Annexed Territories}

Gibraltar(ceded)

British Indian Ocean Territory (BIOT)(ceded)

SBA of Akrotiri \& Dhekelia (ceded)

British Antartic Territory (BAT)(annexed)

\section{Copyright}

Copyright for this article is retained by the author(s), with first publication rights granted to the journal.

This is an open-access article distributed under the terms and conditions of the Creative Commons Attribution license (http://creativecommons.org/licenses/by/4.0/).

\footnotetext{
${ }^{268}$ It is unclear whether this Act has been repealed or not.

${ }^{269}$ Ibid.

${ }^{270}$ Hendry suggests these may also have been annexed in part. However, one would suggest that they were settled.
} 